Energy Systems Environmental Restoration Program ORNL Environmental Restoration Program

\title{
Potential Radiological Exposure Rates Resulting from Hypothetical Dome Failure at Tank W-10
}

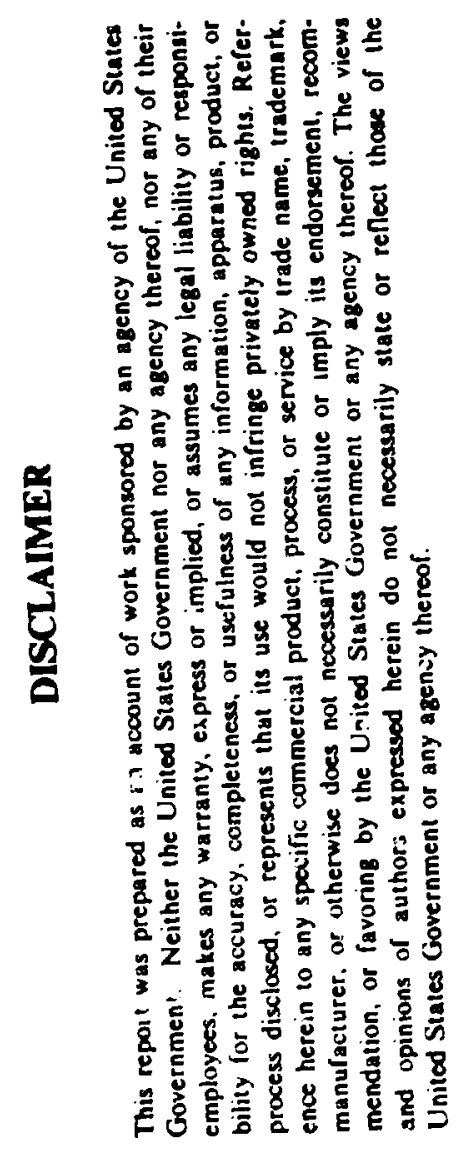

Date Issued-July 1994

Prepared by

Bechtel National, Inc./CH2M Hill/Ogden/Peer

Oak Ridge, Tennessee

under subcontract 12B-99053C

Prepared for

U.S. Department of Energy

Office of Environmental Restoration and Waste Management

under budget and reporting code EW 20

Environmental Restoration and Waste Management Programs

Oak Ridge National Laboratory

Oak Ridge, Tennessec 37831-6285

managed by

MARTIN MARIETTA ENERGY SYSTEMS, INC.

for the

U.S. DEPARTMENT OF ENERGY

under contract DE-AC05-84OR21400

MASTER 


\section{CONTENTS}

FIGURES $\ldots \ldots \ldots \ldots \ldots \ldots \ldots \ldots \ldots \ldots \ldots \ldots \ldots \ldots \ldots$ iii

TABLES $\ldots \ldots \ldots \ldots \ldots \ldots \ldots \ldots \ldots \ldots \ldots \ldots \ldots \ldots \ldots \ldots$ iii

EXECUTIVE SUMMARY $\ldots \ldots \ldots \ldots \ldots \ldots \ldots \ldots \ldots \ldots \ldots \ldots$ iv

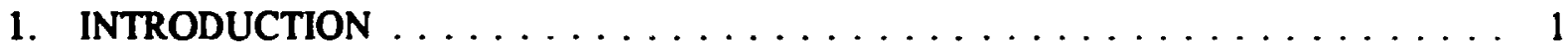

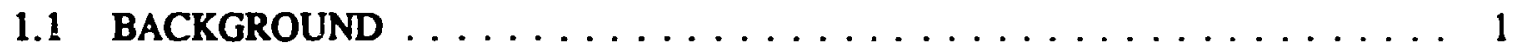

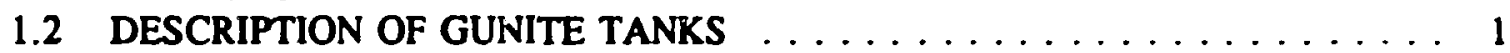

1.2.1 Tank Construction . . . . . . . . . . . . . . . . 1

1.2.2 Operating History of Tanks $W-5$ Through $W-10 \ldots \ldots \ldots \ldots$

1.2.3 Contents of Tank $W-10 \ldots \ldots \ldots \ldots \ldots \ldots$

1.3 OBJECTIVES AND SCOPE LIMITATIONS $\ldots \ldots \ldots \ldots \ldots$

1.4 METHODOLOGY . . . . . . . . . . . . . . . . . . . . 10

2. CALCULATION SET 1: EXPOSURE RATES OUTWARD FROM THE

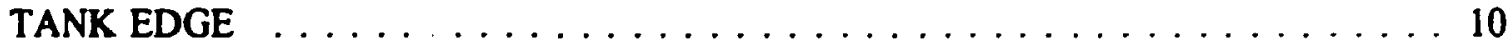

2.1 SOURCE MODELING APPROACH $\ldots \ldots \ldots \ldots \ldots \ldots$

2.2 ASSUMPTIONS AND CODE INPUT $\ldots \ldots \ldots \ldots \ldots \ldots \ldots \ldots$

2.2.1 Source Input $\ldots \ldots \ldots \ldots \ldots \ldots \ldots \ldots \ldots \ldots \ldots \ldots \ldots$

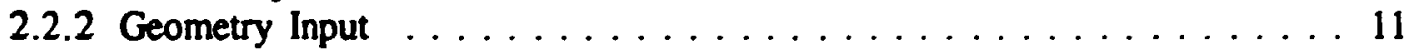

2.2.3 Detector Input $\ldots \ldots \ldots \ldots \ldots \ldots \ldots \ldots \ldots \ldots \ldots \ldots$

2.3 RESULTS AND ANALYSES $\ldots \ldots \ldots \ldots \ldots \ldots \ldots \ldots \ldots$

3. CALCULATION SET 2: EXPOSURE RATES ABOVE THE TANX $\ldots \ldots \ldots \ldots 18$

3.1 ASSUMPTIONS AND CODE INPUT $\ldots \ldots \ldots \ldots \ldots \ldots \ldots$

3.2 RESULTS AND ANALYSES $\ldots \ldots \ldots \ldots \ldots \ldots \ldots \ldots \ldots \ldots$

4. CALCULATION SET 3: EXPOSURE RATE IN BUILDING 150 FT AWAY $\ldots \ldots 21$

5. CALCULATION SET 4: TOTAL EXPOSURES FOR TWO WORKER

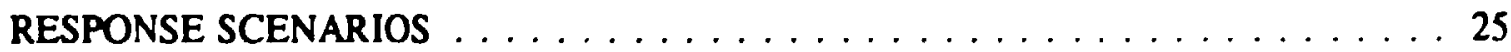

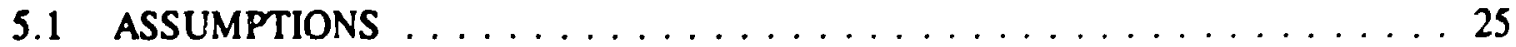

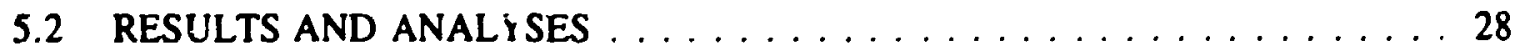

6. CONCLUSIONS . . . . . . . . . . . . . . . . . . . . . . . . . 29

REFERENCES AND BIBLIOGRAPHY $\ldots \ldots \ldots \ldots \ldots \ldots \ldots \ldots \ldots \ldots \ldots$

APPENDIX A: COMPUTER CODE DESCRIPTIONS $\ldots \ldots \ldots \ldots \ldots \ldots \ldots$

APPENDIX B: MICROSHIELD INPUT FILES $\ldots \ldots \ldots \ldots \ldots \ldots$ B-1

APPENDIX C: QAD-CGGP INPUT FILES $\ldots \ldots \ldots \ldots \ldots \ldots \ldots \ldots$ C-1 


\section{FIGURES}

1 Location of Gunite tanks in ORNL's main plart area $\ldots \ldots \ldots \ldots \ldots$

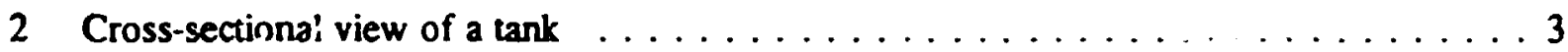

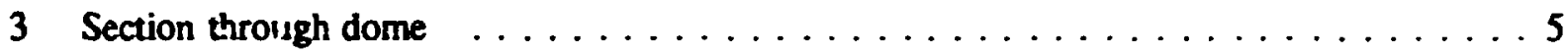

4 Typical tank configuration showing sampling location $\ldots \ldots \ldots \ldots$

5 Tank cross-section geometry used for the QAD-CGGP shielding code model,

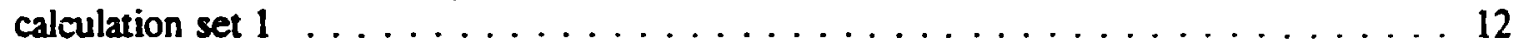

6 Exposure rates near edge of tank $\mathrm{W}-10$, calculation set $1 \ldots \ldots \ldots \ldots$

7 Exposure rates around tank W-10 at varıous distances from tank edge, calculation set I . 19

8 Tank cross-section geometry used for the QAD-CGGP shielding code model,

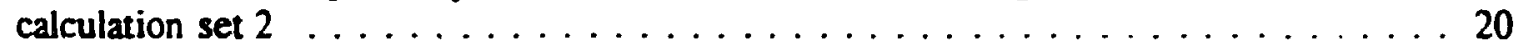

9 Exposure rates from platform center to edge of tank W-10, calculation set $2 \ldots \ldots 24$

10 Investigator exposure scenarios, calculation set $4 \ldots \ldots \ldots \ldots \ldots \ldots \ldots$

1i Fugitive exposure scenarios, calculation set $4 \ldots \ldots \ldots \ldots \ldots \ldots \ldots \ldots \ldots$

\section{TABLES}

1 Gunite tank $\mathbf{W}-10$ estimated radionuclide inventory $\ldots \ldots \ldots \ldots \ldots$

2a. Calculation set I: exposure rates as a function of distance from tank edge to $25 \mathrm{ft}$

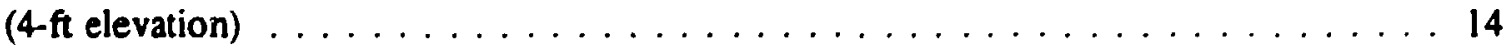

2b. Calculation set 1: exposure rates a, a function of distance from tank edge to $25 \mathrm{ft}$ (o-ft elevation)

3a. Calculation set 2: exposure rates as a function of distance from tank platform center to tank edge (4-ft elevation)

3b. Calculation set 2: exposure rates as a function of distance from tank platform center

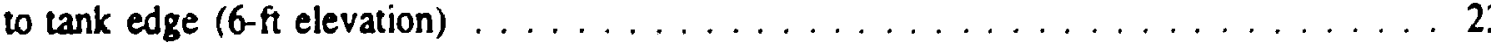

4. Total exposures (above background) for worker response scenarios . . . . . . . . 28 


\section{EXECUTTVE SUMMARY}

Pupose

The main plant area a Oak Ridge Naional Laboratory (ORNL) cortains 12 buried Gunite tanks that were used for the storage and transfer of liquid radioactive waste. Although the tanks are no longer in use, they are bnown to contain some rexidual contaminated sludges and liquids. In the event of an accidental tunk dome faibure, however untikely, the liquids, studges, and radionctive contrinares within the tank wills theaselves conld crease radistion fields and result in sbovebecteround exposures to worters nearby.

This Tecthiod Memorantum documents a series of calculations to extimate potential rediological exposure rates and cotal exposures to workers in the event of a hypothetical collapse of a Gunite tank dome. Calculuions were performed epecifically for tunk W-10 becuse it contains the largest radioactivity inventory (approximutely heif of the total activity) of all the Cunite tents. These calculations focus onty on external, direct gamma exposures for prescribed, hypothetical exposure scenarios and do not address other possible tank fsilure modes or roustes of exposure. The cilculations were performed with established, point-kernel gamma ray modeling codes.

\section{Approach and Assumptions}

The primary raliation sources in the tank are the bottom iayer of sludge, the liquid layst on top of the shodge, and the contaminated tank wall. Eacin set of calculations provides results for two separate modeled source combinations, or "source terms," consisting of (1) the sludge plus the tank will, and (2) the sludge plus the liquid plus the tank wall. The first source term (sludge plus tank will) assumes that the hypothetical accident which causes the dome to collapse also creates cracks in the tank walls that allow the liguid to escape. The second source term (sludge plus liquid plus tank wall) assumes that all the primary radiation sources are present and contribute to the exposure.

Three other principal assumptions used for developing the code model are listed below.

- Although the failure of the dome would cause the concrete and dirt overburden to collapse into the tank, thereby forming an effective gamma-attenuating barrier to the tank contents, the calculations assume that the residral overburden materials provide no sniclding of the tank's radioactive contents.

- A sensitivity analysis of the tank contaminants showed that most of the gamma exposure (>95\%) was due to the cesium-137 (and barium-137n dauginter) activity in tank W-10; therefore, the source term in the model only used cesium-137 activities. The cesium source strengths used for the calculations were $490 \mu \mathrm{Ci} / \mathrm{cm}^{3}$ (or 11,000 Ci total) for the 4.8-in.-deep shodge and $6.7 \mu \mathrm{Ci} / \mathrm{cm}^{3}$ (or $1700 \mathrm{Ci}$ total) for the 55 -in.-deep liquid.

- The source strength used in the modeling of the tank wall was assumed to be $20 \mu \mathrm{Ci} / \mathrm{cm}^{3}$ (or $89 \mathrm{Ci}$ total), per Energy Systems' recommendation. However, this value, which has not been yerified with actual measuremems, is larger by a factor of 3 than the modeled liquid source strength of $6.7 \mu \mathrm{Ci} / \mathrm{cm}^{3}$. The cesium contamination was assumed to be uniform over the tank wall surface to a depth of 1 in. 
To facilitate discussion of the modeling results, the calculations have been divided into the four sets discussed below.

\section{Calcularion Set 1: Expasure Rates Radially Ounard from the Tank Edge}

This calculation set estimates exposure rates as a function of distance from the tark edge out to a total distance of $150 \mathrm{ft}$, at heights of $4 \mathrm{ft}$ and $6 \mathrm{ft}$ above the ground surface. The results of this calculation set show that the exposure rates reach a maximum at the tank edge and then iall off repidly as a function of distance from the tunk, reaching area background between 25 and $50 \mathrm{f}$ from the tank edge. The maximum vahues at the tank edge are $2.5 \times 10^{4}$ to $2.7 \times 10^{6} \mathrm{mR} / \mathrm{h}$ for the first source term (shudge phus wall; no liquid layer present) and $1.2 \times 10^{3}$ to $1.3 \times 10^{3} \mathrm{mR} / \mathrm{h}$ for the second source term (shedge phes liquid plus wall; all primary sources present).

Comparison of the two source term results shows higher potential exposure rates from sludges that do not have a liquid cover (the first source term); these results indicate that although the liquids contain radiosctive materials, they still provide a significant shielding effect for the shudges.

\section{Calculation Set 2: Exposure Rates Above the Taik}

This calculation set extimates exposure rates sbove the tanl as a function of distance from the tank center out to a thtal radius of $25 \mathrm{ft}$ (tank edge), at heights of $4 \mathrm{ft}$ and $6 \mathrm{ft}$ above a hypothetical platform that spans the tank and is situated 5 it above the ground surface. The platform is assumed to be invisible to (i.e., does not shield) gamma rays emanating from the tank.

The exposure rate profiles as a function of radial position are relatively flat. The exposure rates range from $2.1 \times 10^{4} \times 103.2 \times 10^{4} \mathrm{mR} / \mathrm{h}$ for the first source term (sludge plus wall; no liquid layer present) and $9.6 \times 10^{2}$ to $1.7 \times 10^{3} \mathrm{mR} / \mathrm{h}$ for the second source term (sludge plus liquid plus wall).

\section{Calculation Set 3: Exposure Rate in Building 150 ft Away}

To model the potential exposure on the second floor of a hypothetical building $150 \mathrm{ft}$ north of tank $W-10$, this set estimates the exposure rate at a location $150 \mathrm{ft}$ from the tank edge, at a height of $20 \mathrm{ft}$ abcuve the ground. The exposure rates calculated in this set were insignificant (close to zerv); therefore, no significant changes in local area background would be expected from direct exposure resulting from the hypothetical dome collapse modeled.

\section{Calculation set 4: Tozal Exposures for Two Hypotherical Worker Response Scenarios}

Using the exposure rates from sets 1 and 2, this calculation set computes total gamma radiation exposures for two hypothetical worker exposure scenarios: (1) the "investigator" scenario, where a worker is attracted by the accident-generated noise of a dome collapse, but quickly leaves the area after noting the extent of the damage; and (2) the "fugitive" scenario, where a worker who is present on the platform above the tank when the postulated accident occurs flees the immediate area. The calculation parameters with regard to hypothetical worker response, evacuation routes, and exposure times are conservative. Ignored are the facts that the tank areas are roped off and restricted, and that ORNL's radiation workers are trained to minimize their exposure in the event of an accident or an 
wifergericy siturion. These (worst case) scenarios are provided as only two of many possible expegers simurions that could be studied.

Entineted exposures for both investigator and fugitive scenarios were the some order of argonitite for a particular source term. For the first (shudge plus wall) source term, the exposures (wiich are in excess of bactground) are roughly equivalent to the average annual exposure to natural backgroxis (approximately $\mathbf{2 7 0}$ mrem/year). For the second (sludge phus liquid plus wall) source trm, totai exposures were an order of magnitude less thon for the first source term because of the therineting effect on the shudge by the liquid layer. In both worker response scenarios considered, stus extimased total exposure vahes for the hypothetical worker are below the anmal regulatory limits Fuctmmended by ORNL; ORNL's administrative goa' is more than a factor of 2 greater than the toaximum calculated exposure.

\section{stistutionaí Observations}

ine conseryative nature of these calculations (e.s., lack of overburden, worter exposure paj lefeis an and anmal regulatory limits, the calculations (and scenarios) could be modified, if desiren, $z ;$, sisuiate less conservative (more realistic) accident situations.

The resutio of this study should not be directly extrapolated to other Gunite tanks without appropizite analysis. As was shown by this study, the contamirated liquid covering the sludge provis a contiderable amoum of shielding for radiation fields generated by sludge radiomelides. The-gisi. other Gunite tanks with minimal or no liquids covering the sludge could also be consideres for a sudy auch as this. As part of ORNL's planning activities for the Gunite tanks, addiciral nodeling could also be performed to study various siudge/liquid remediation scenarios or other typothetical accident scenarios. Additional tank characterization could also be performed to identity the extent of penetration and concertration of radioactive contaminants in the wall. 


\section{INTRODUCTION}

\subsection{BACKGROUND}

The Oak Ridge National Laboratory (ORNL) main plant area contains 12 underground Gunite tanks (see Fig. 1) that were used for the storage and transfer of liquid radioactive and hazardous wastes before they were removed from service. These tanks were built in 1943 using a Gunite construction process in which a mixture of sand, cement, and water is applied in layers by spraying onto formed steel reinforcement bars and/or welded wire mesh. They have a circular shape in plan view, with vertical sidewalls and a domed top, and are buried under about $6 \mathrm{ft}$ of compacted soil. The Gunite tanks with the largest capacity are tanks W-5 through W-10, located in the South Tank Farm.

The Gunite tanks contain more than $95 \%$ of the documented inventory of radionuclides within the inactive waste management units in ORNL's main plant area. Although there have been no documented releases from these tanks, their age and uncertain structural integrity suggest the potential for future release. Plans are being prepared to minimize or control the potential for and effects of leakage or failure of the containment structures. These effects may include contaminant migration into surrounding soil, with subsequent contamination of other environmental media and exposure of ORNL personnel through airborne contamination or direct radiation exposure.

This Technical Memorandum documents a series of calculations to estimate potential radiological exposure rates above and surrounding a Gunite tank in the event of a tank dome collapse. The exposure rates are then used to derive total exposures for assumed exposure situations. Specific calculations were performed for tank W-10 because it contains the largest inventory of radioactivity of all the Gunite tanks. These calculations focus only on external, direct garnma exposures for prescribed, hypothetical exposure scenarios and do not address other possible tank failure modes or routes of exposure. The calculations are provided to support ORNL's planning efforts for the Gunite tanks, but they are not intended as a complete assessment of ali possible exposure pathways or risk scenarios.

This introduction provides a general description of Gunite tanks (Sect. 1.2), a delineation of specific calculation objectives and scope limitations (Sect. 1.3), and a brief discussion of the calculational approach or methodology (Sect. 1.4).

\subsection{DESCRIPTION OF GUNITE TANKS}

\subsubsection{Tank Construction}

Tanks W-5 through W-10 are large (170,000-gal capacity) Gunit: tanks arranged in two rows of three tanks each, with a center-to-center distance of $(\mathcal{J}) \mathrm{ft}$ between idjacent tanks. The tanks were constructed by excavating a large shal'ow basin, prouring individual concrete pads directly on bedrock, erecting the tanks, and backfilling the entire area.

The inside diameter of the tanks is $50 \mathrm{ft}$, and the 12 -ft vertical sidewalls are $7.5 \mathrm{in}$. thick. The oottom Gunite liner is 3 in. thick on top of the concrete pad, and the domes are 10 in. thick, increasing in thickiless at the point where the dome meets the tank walis. The dome curves upward approximately $6 \mathrm{ft}$ from its outer edge to its center. Figure 2 shows a cross-sectional view of a 


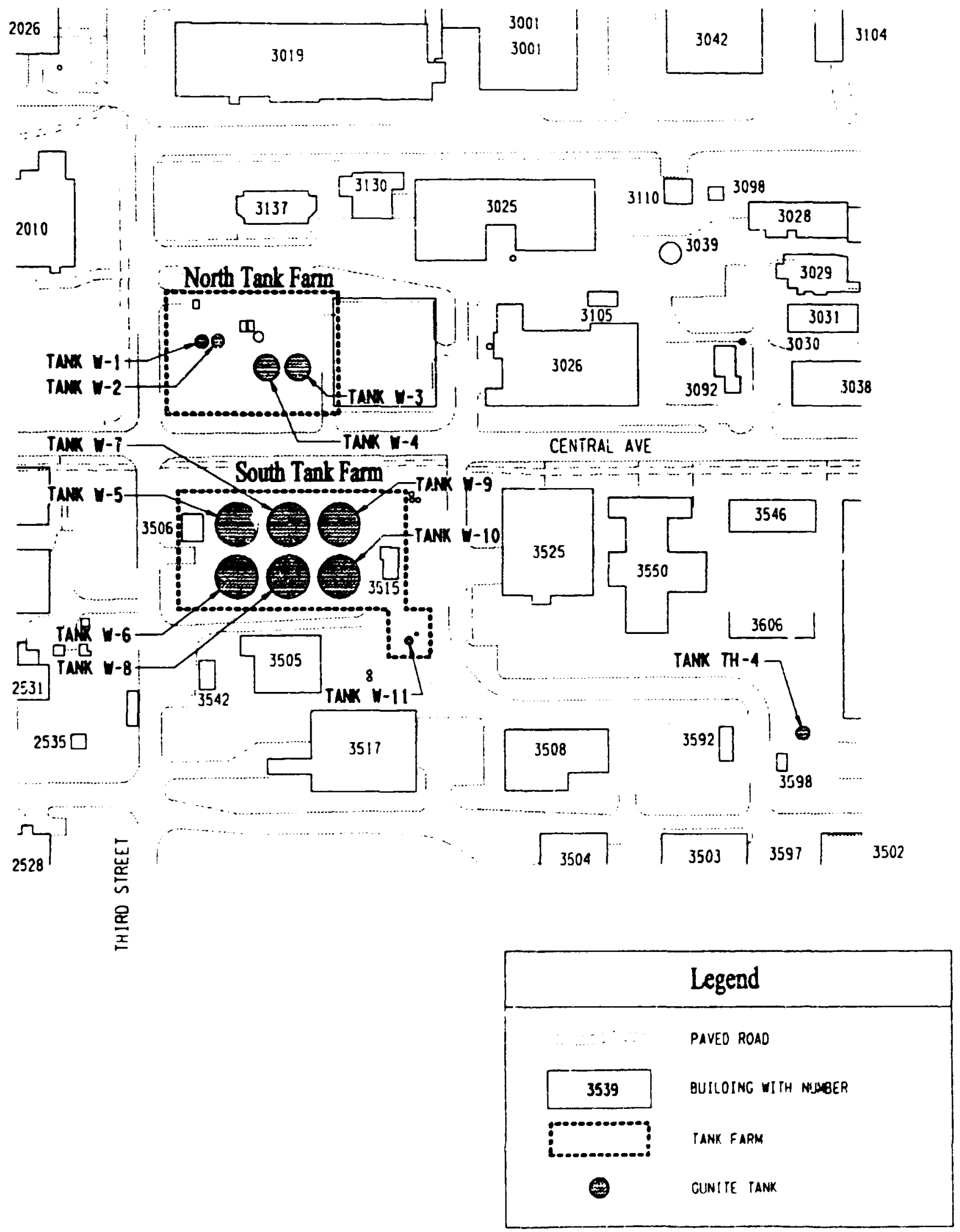

Fig. 1. Location of Gunite tanks in ORNL's main plant area. 


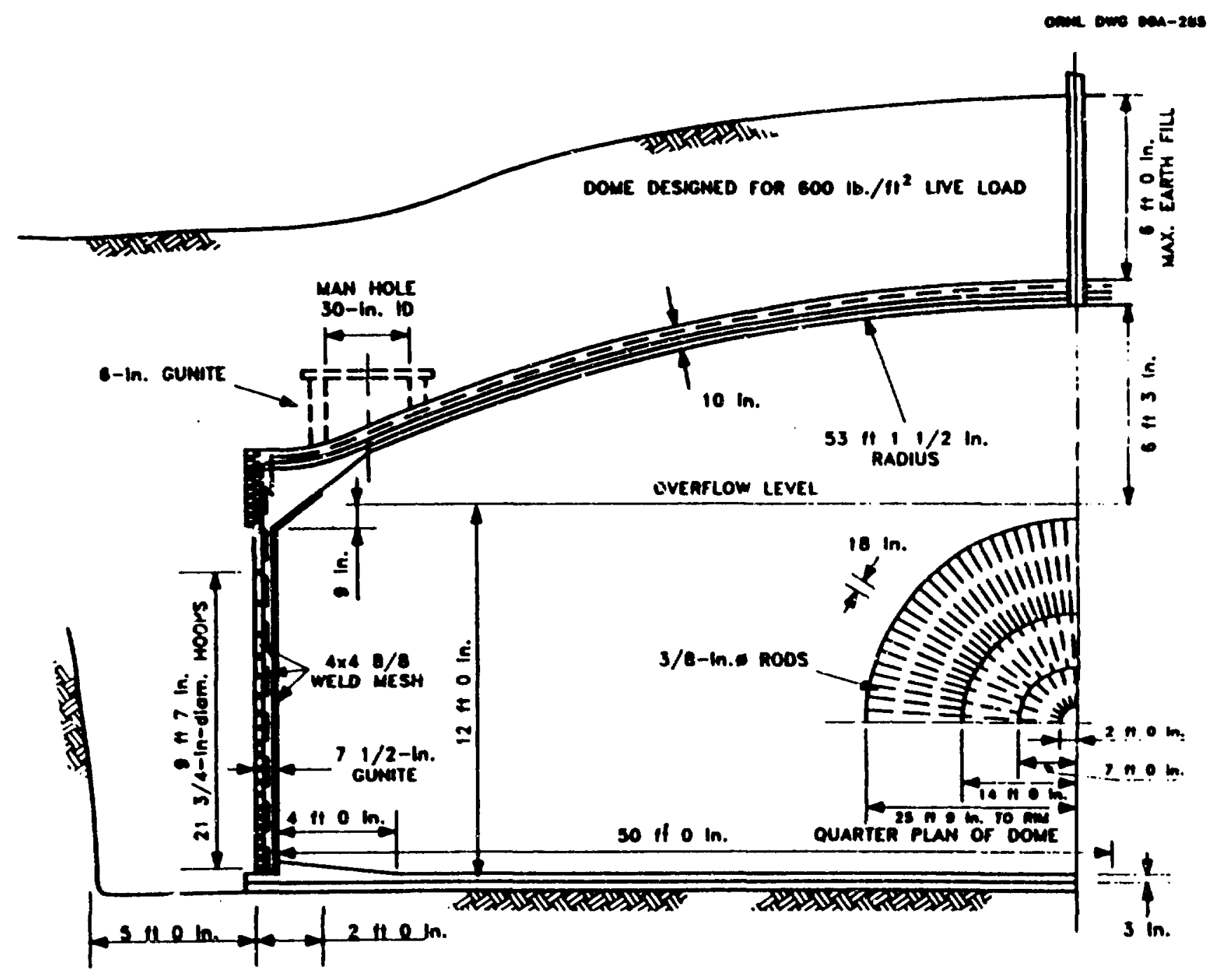

Fig. 2. Cross-sectional view of a tunk. 
Gunite tank, and Fig. 3 shows an enlarged sectional view of the area where the tank dome neets the vertical sidewalls.

An analysis of tanks W-5 through W-10 was peiformed in 1986 to assess their structural adequacy when subjected to seismic loads. The calculations performed in the structural analysis (Fricke 1986) revealed that the reinforcement steel in the part of the tank where the top dome meets the vertical sidewalls does not have sufficient strength to handle the size of the loads that were assumed in the original design specifications, without the support of the prestressed steel hoops in that part of the tank. This apparent weakness may be the result of overly conservative assumptions concerning the remaining strength in the steel used to form the hoops in the dome edge :egion or in the other reinforcing steel and the concrete in that area. These assumptions would theorevically allow creep and shrinkage in the concrete, losses in strength due to internal frictions, deformation at the dome ring, and excessive bending in that part of the tank. Given the absence of as-built drawings, it is also possible that design and/or material specifications were exceeded in the construction, resulting in greater strength than specified in the design. Because of uncertainties in estimating the variables used for the analysis, the actual structural behavior of these tanks is difficult to predict.

The backfill mate $i$ ill around each tank is a 3- $\mathrm{ft}$ layer of 2 -in. crushed stone surrounding the tank from the base to the top. The concrete pads under the tanks have larger diameters than the tanks and curb and gutter systems that drain via a 6-in. terra cotta drain tile system to six individual dry wells, all of which connect to a common drain for pumping to the equalization basin. In the event of a leak, the liquid was intended to flow down through the crushed stonc, collect in the saucer-like concrete pad, and be captured in the dry wells, where routine monitoring would detect the leak.

\subsubsection{Operating History of Tanks W-5 Through W-10}

The six main Gunite tanks were originally built for permanent storage of radioactive liquid waste produced by the plutonium pilot plant and were intended to be operated in pairs. They were to receive waste from the building drains uphill to the north and to overflow from one tank to the next toward the south. W-5 initially received radioactive liquid chemical waste and overflowed into W-6, W-7 initially received liquid uranium waste and overflowed into $W-8$, and $W-9$ initially received liquid uranium waste and overflowed into W-10 (Mynatt and Webster 1963). As the laboratory grew, the storage tanks became inadequate to hand.e the volume of liquid waste that was being generated. The wastes were precipitated in the tanks by raising the $\mathrm{pH}$ with sodium hydroxide, and the supernatant was decanted to waste holding basin 3513 and subsequently discharged to White Oak Creek. This practice changed in 1949 when a new process was begun to concentrate the effluent from these tanks using a pot-type evaporator. The concentrate from the evaporator was returned to one of the storage tanks, and the condensate was discharged to White Oak Creek.

The use of each tank changed according to the growing needs of the laboratory over the years. As much as 130 tons of uranium were reclaimed from W-7, W-8, W-9, and W-10 betweer 1952 and 1957, making more rooin for waste in the tanks (Mynatt and Webster 1963). By the early 1960 s, W-7, W-7, and W-10 were not being used, but they contained a solution of water, $\mathrm{NaOH}$, and radinactive sludges. Mcst of the tanks were removed from service in 1978, and most of the liquid and sludge they contained was removed by sluicing; however, some liquid and sludge remain. 


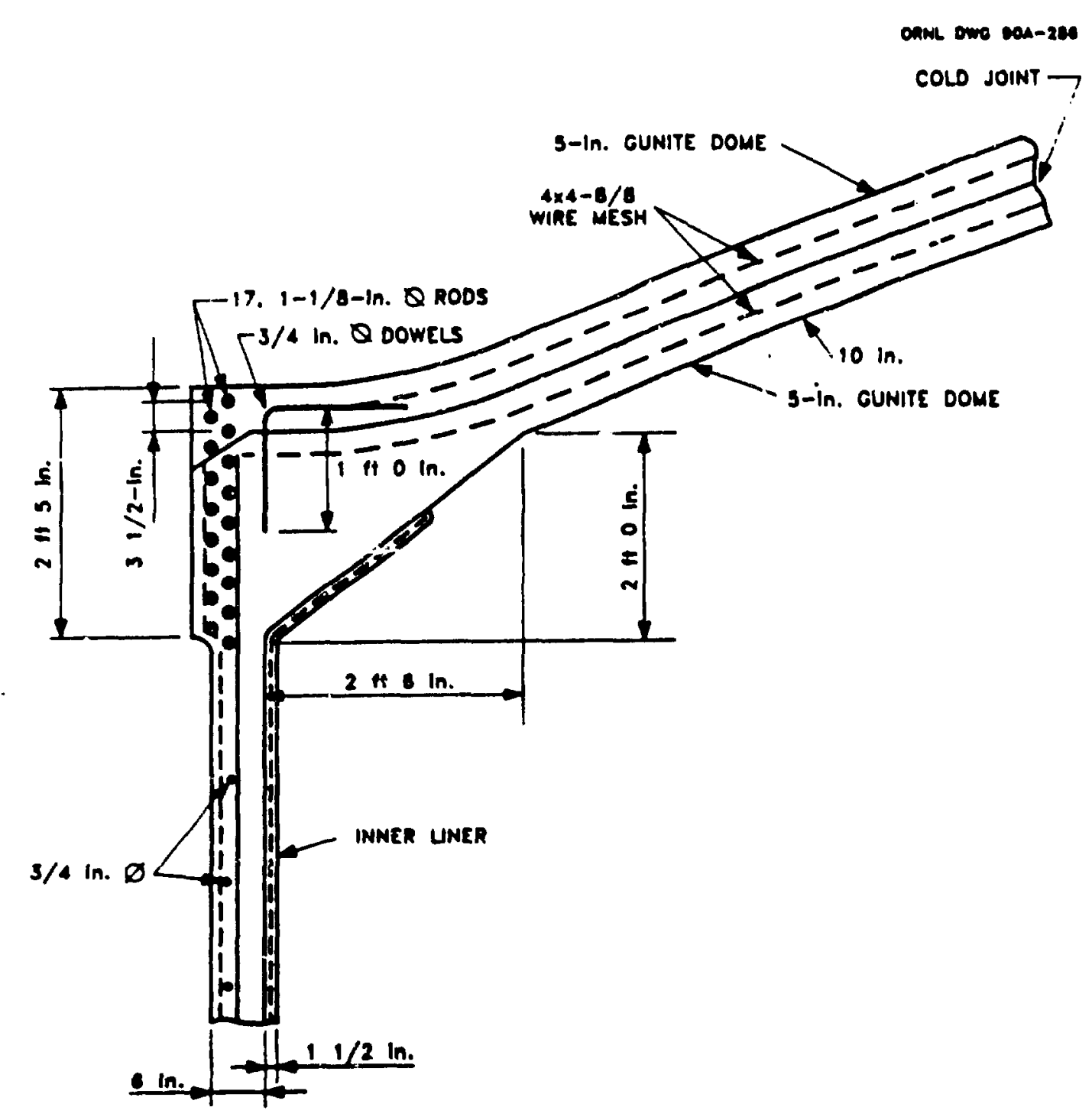

Fig. 3. Section through dome. 


\subsubsection{Contents of Tank W-10}

Tank W-10 cortains almost 5 in. of contaminated sludge covered by slightly more than $4.5 \mathrm{ft}$ of contaminated liquid. The liquid and sludge contained within the Gunite tanks, including W-10, have been sampled and analyzed by ORNL (Autrey et al. 1990; ORNL 1992a). Approximately 50\% of the total activity in the Gunite tanks is contained in tank W-10 (Bechtel 1991). Table 1 presents the total activity of radionuclides in the sludge and liquid of W-10, as reported by Bechtel (1991): activities in siudge range from $0.14 \mathrm{Ci}$ tritium to $11,000 \mathrm{Ci}$ cesium-137; activities in liquids range from $0.01 \mathrm{Ci}$ plutonium-239 to $1700 \mathrm{Ci}$ cesium-137. These estimates were generated ty using published maximum radionuclide concentrations for the tank contents and tank volumes and are likely to provide a conservative estimate of the liquid inventories. However, the sludge results are not necessatily conservative: the sludge is likely to be heterogeneous, but tite samples were collected from only one penetration in the tank (Fig. 4). In addition, sample quantities were limited to minimize radiation exposure to field personnel.

The principal gamma zmitters in Table $\mathbb{i}$, and the radionuclides expected to have the most impact on cirect gamma exposure, are cesium-137 (the radionuclide with the largest activity in the tank sludge and liquid), cesium-134, cobalt-60, eutopium-152, and europium-154. Some of the daughters in the uranium and p'utonium decay chains are also gamma emitters.

\subsection{OBJECTIVES AND SCOPE LIMITATIONS}

This document presents a radiological exposure model for a hypothetical complete dome collapse of tank W-10 and estimates gamma exposure rates and total gamma exposures for workers under postulated worst-case conditions. To facilitate discussion of the modeling and associated results, the salculations are divided into four sets.

- Calculation Set 1: Exposure Rates Radically Ourward from the Tank Edge (see Secr. 2). This calculation set estimates exposure -ates as a function of distance from the tank edge out to a total distance of $150 \mathrm{ft}$, at heights of $4 \mathrm{ft}$ and $6 \mathrm{ft}$ above the ground surface. The 4-ft and 6-ft heights represent approximate waist and head heights for a worker.

- Calculation Set 2: Exposure Rates Above the Tank (see Sect. 3). This calculation set extimates exposure rates above the tank as a function of distance from the tank center out to a total radius of $25 \mathrm{ft}$ (tank edge), at heights of $4 \mathrm{ft}$ and $6 \mathrm{ft}$ above an imaginary working platform situated abuve the tank.

- Calculation Set 3: Exposure Rase in Building 150 fi Away (see Sect. 4). This calcuiation set estimates the exposure rate at a hypothetical building $150 \mathrm{ft}$ from the :ank edge, at a height of $20 \mathrm{ft}$ above the ground. 
Table 1. Gunite tank W-10 estimated radionuclide inventory

\begin{tabular}{l|c|c}
\hline & \multicolumn{2}{|c}{ Tank 'N-10 } \\
\hline Radionuclide & $\begin{array}{c}\text { Sludge } \\
(\mathrm{Ci})\end{array}$ & $\begin{array}{c}\text { Liquid } \\
(\mathrm{Ci})\end{array}$ \\
\hline${ }^{241} \mathrm{Am}$ & $4.4 \mathrm{E}+\infty$ & $*$ \\
${ }^{24} \mathrm{Cm}$ & $4.6 \mathrm{E}+01$ & $*$ \\
${ }^{60} \mathrm{Co}$ & $1.3 \mathrm{E}+01$ & $1.0 \mathrm{E}+\infty 0$ \\
${ }^{134} \mathrm{Cs}$ & $1.4 \mathrm{E}+\infty$ & $*$ \\
${ }^{137} \mathrm{Cs}$ & $1.1 \mathrm{E}+04$ & $1.7 \mathrm{E}+03$ \\
${ }^{152} \mathrm{Eu}$ & $4.5 \mathrm{E}+\infty 0$ & $*$ \\
${ }^{154} \mathrm{Eu}$ & $7.9 \mathrm{E}+\infty 0$ & $*$ \\
${ }^{3} \mathrm{H}$ & $1.4 \mathrm{E}-01$ & $1.0 \mathrm{E}+00$ \\
${ }^{231} \mathrm{Pu}$ & $2.9 \mathrm{E}+01$ & $*$ \\
${ }^{239} \mathrm{Pu}$ & $1.1 \mathrm{E}+01$ & $1.4 \mathrm{E}-02$ \\
${ }^{30} \mathrm{Sr}$ & $8.5 \mathrm{E}+03$ & $8.7 \mathrm{E}+00$ \\
${ }^{23} 3 \mathrm{U}$ & $2.1 \mathrm{E}+\infty$ & $5.1 \mathrm{E}-02$ \\
${ }^{254} \mathrm{U}$ & $1.3 \mathrm{E}+\infty$ & $2.2 \mathrm{E}-02$ \\
\hline
\end{tabular}

Source: Bechtel, "Radionuclide Inventory in the WAG 1 Inactive Tanks," 01-TB-18, Rev. 0, Oak Ridge, Tennesses.

*Asterisk indicates that data are not available. 


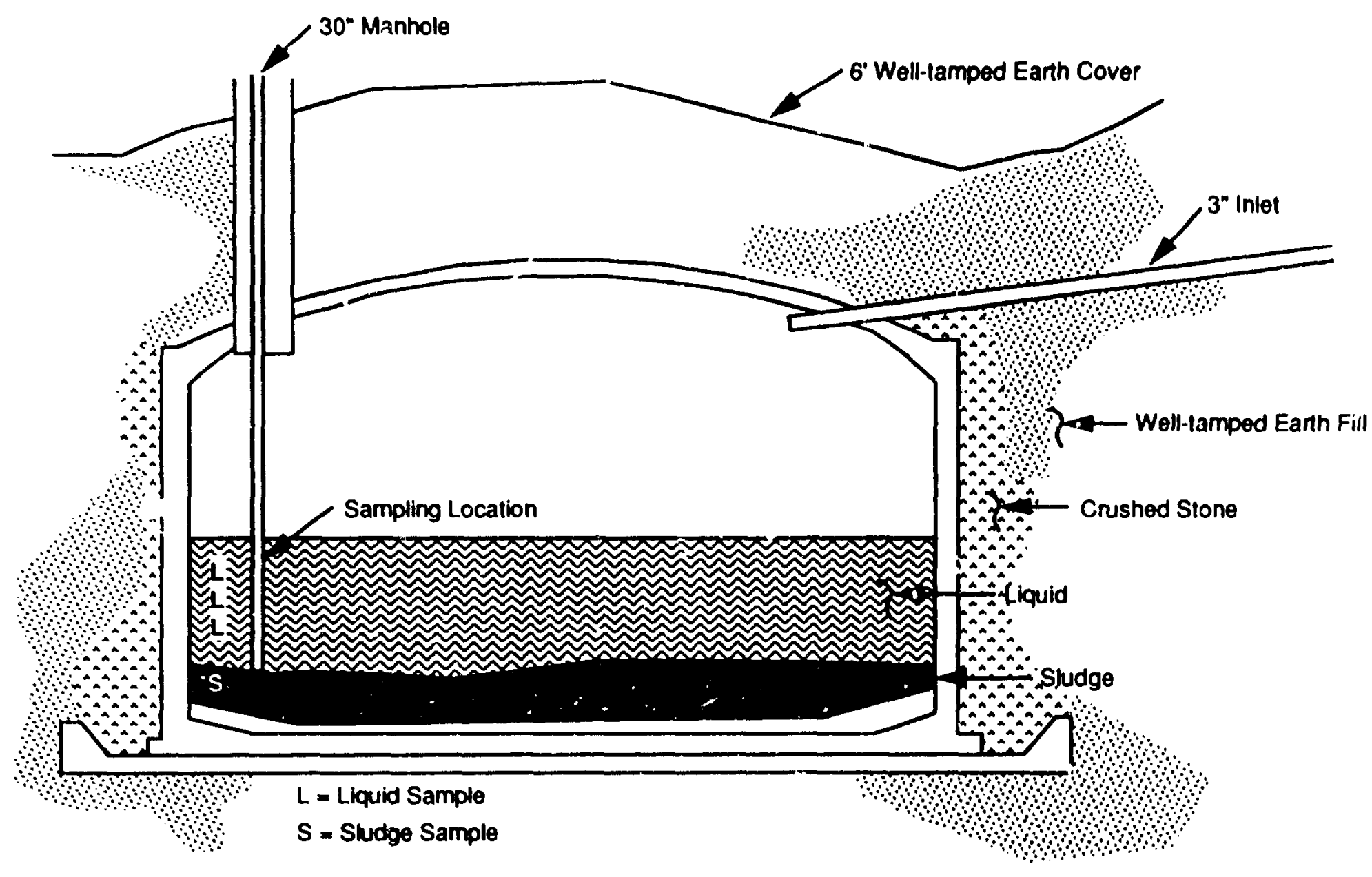

Fig. 4. Typical tank conniguration showing sampling location. 
- Calculation Set 4: Total Exposures for Two Hypothetical Worker Resporse Jicenarios (see Sect. 5). Using the exposure rates from sets 1 and 2, this calculation set computes total gamma radiation exposures for two hypothetical worker exposure scenarios: (1) the "investigator "scenario, where a worker is attracted by the accident-generated noise of a dome collapse but quickly leaves the area after noting the extent of the damage; and (2) the "fugitive" scenario, where a worker who is present on the platform above the tank when the accident occurs flees the immediate area.

The primary radiation sources in the tant are the layer of sludge at the bottom, the liquid layer on top of the sludge, and the contami lated tank wall. Each calculation set provides results for two separate modeled source combirations, or "source terms," consisting of (1) the sludge plus the tank wall, and (2) the sludge plus the liquid plus the tank wall. The first source term (sludge plus tank wall) assumes that the hypothetical accident which causes the dome to collapse also creates cracks in the tank walls or floor that allow liquid to escape. In this instarice, only contamination in the sludge and tank walis contributes to the potential exposures above or around the tank. The second source term (sludge plus liquid plus tank wall) asstimes that all the primary radiation sources contribute to the exposure. It is important to note, however, that the sludge emanations in this second source term are partially shielded by the liquid layer above the sludge.

The model assumptions are generally conservative and may in some cases be considered conservative to the point of being unrealistic; however, this lack of realism is deemed acceptable for this series of calculations so as to meet the stated objective of estimating upper limit or worst-case direct gamma exposures. A good example of a conservative assumption used in the calculations is that although the failure of the dome would cause the concrete and soil overburden to collapse into the tank, thereby forming an effective gamma-atteruating barrier to the tank contents, the calculations assume that the residual overburden materials provide no shielding of the tank's radioactive contents (i.e., the overburden in essence becomes "ronexistent" after the collapse and is not included in the model). If the overburden had been included in the calculations as a shielding material for the sludge and liquid, the calculated exposure rates would have been lower.

The calculations provide direct gamma exposures under prescribed conditions, and the calculational pproach (as shown in Sect. 2) provides insight into the shis,lding protection offered by the contaminated liquids for the underlying sludge, as well as the contribution of the cesium-137 activity to the total gamma exposure. However, this document is not sufficient for, nor intencied for, safety analyses of other possible exposure scenarios such as sludge/liquid remediation, dome iemoval, tank leaks and contaminant recovery, criticality, or airborne releases.

A s stated, the modeling results are specifically for tank W-10. Although tank W-10 has the inighest reported activity of any of the Gunite tanks, extrapolation of tank W-10 exposure results to other Gunite tanks should only be done after careful comparative analysis of the other tanks and their contents, and in consultation with qualified technical personnel. Alternatively, for the purposes of comparison, the same type of study conducted for tank W-10 could be conducted directly for other Gunite tanks in the South Tank Farm area. 


\subsection{METHODOLOGY}

The exposure rates determined in caiculation sets 1,2, and 3 were computed using the gamma ray shielding codes QAD-CGGP (Cain 197') and, to a much lesser extent, MicroShield, Version 4 (Grove Engineering 1987). Both codes are generally well known and receive widespread use in the nuclear engineering community, and verified and validated versions of these codes exist on Bechtel's computer network.

QAD-CGGP is a point-kernel (ray-tracing technique) code for calculating gamma ray penetration through various shield configurations defined by combinatorial geometry specifications. Q.AD-CGGP was used to perform exposure calculatiors because of its versatility in geometry conbinations and exposure point locations. MicroStield is also a point-kernel code but with menu-driven features that allow for simpler and quicker, though less flexible, code input than QAD-CGGP. MicroShie'd was used to perform sensitivity analyses on source composition (loading) because it is relatively simpic to use and modify for different radionuclides. These codes are discussed in more de'ail in Appendix A. Input files for QAD-CGGP and MicroShield used in this study are given in $A^{-}$ivendices $B$ and C for those readers farniliar with the codes or who have access to code documentation

Calculation sets 1 through 4 are discussed in Sects. 2 through 5 , respectively. Each section lists the approach and assumptions used to make the calculations in a set, presents the results of the calculation set, and offers analysis of the results, as appropriate. Details regarding input parameters for QAD-CGGP and MicroShield, as well as copies of input and output files, are present 1 and explained in Bechtel Calculation No. 01-CA-09 (W-10 Tank Exposure Due to Hypothetical Tank A.ccident), Bechtel Calculation No. 01-CA-10 (W-10 Tank Exposure Map Extended to $24 \mathrm{ft}$ from the Edge of the Tank), and Bechtel Calculation No. 01-CA-28 (Exposure Rate Estimates Due to Tank W-10 Wall).

\section{CALCULATION SET 1: EXPOSURE RATES OUTWARD FROM THE TANK EDGE}

This calculation set estimates the exposure rates as a function of distance from the tank edge out to a total distance of $150 \mathrm{ft}$, at heights of $4 \mathrm{ft}$ and $6 \mathrm{ft}$ above the ground surface.

\subsection{SOURCE MODELING APPROACH}

The three primary sources of gamma -adiation consisted of the contaminated sludge, liquid, and tank wall. Exposure rates were to be provided for

- a situation where the liquid had escaped from the tank and only the sludge and tank wall were gamma ray contributors, and

- a situation where all three primary sources were contributors.

Since the codes only model one source region at a time (i.e., each primary source is cumposed of a different material, and oniy one of the materials input to the code can be designated as a source 
in a code nun), individual contributions to the exposure rate must be determined for each source and then added together to obtain the total exposure rates.

Individual calculations were performer for (1) the s!udge as the wurce without an overlying layer of liquid, (2) the tank walls as the sou:ce with a sludge layer acting as a shield for the sludgecovered portion of the wall (no liquid layer present), (3) the liquid as the source, (4) the sludge as the source with an overlying layer of liquid acting as a shield or atienuator for the sludge contarninants (i.e., the liquid was not a source), and (5) the tai: $x$ walls as a source with the sludge and liquid layers acting as a shield for that portion of the wall below the liquid surface. The results of these calculations were summad together in specific ways to give total contributions; specifically,

- exposure rate results from individual calcula:jons (1) and (2) above werz added together to give the exposure rates for a slucige-plus-tank-wall combined source, and

- exposure rate results from individual calculations (3), (4), and (5) soove were added together to give the exposure rates for a sludge-plus-liquid-plus-tank-wal! combined source.

\subsection{ASSUMPTIONS AND CODE INPUT}

\subsubsection{Source Input}

The depths of the sludge and liquid (see Sect. 2.2.2) were measured during the inactive waste tank sampling project in August 1988 . Given the measured depths and known tank dimensions, the volumes of sludge and liquid used for the code model were $5930 \mathrm{gal}(22,440 \mathrm{~L})$ and $67,330 \mathrm{gal}$ $(254,830 \mathrm{~L})$, respectively.

No information was reported on the density of sludge material collected during the sampling effort. For this study, the density of the sludge was assumed to be $1.5 \mathrm{~g} / \mathrm{cm}^{3}$, and the density of the liquid was assumed to be $1 \mathrm{~g} / \mathrm{cm}^{3}$.

A sensitivity analysis using MicroShield showed that most of the gamma exposure ( $>95 \%$ ) was due to the cesium-137 activity; therefore, the source term in the QAD-CGGP model only lises cesium-137 radionurlide activities. (Note: cesium-137 actually decays by beta emission to barium$137 \mathrm{~m}$, which in turn decays by gamma emission to the ground state of barium.)

The source strengths used by the model for the sludge and liquid waste were assumed to be those reported in Table 1: $11,000 \mathrm{Ci}$ (or $490 \mu \mathrm{Ci} / \mathrm{cm}^{3}$ ) cesium-137 in the sludge and $1700 \mathrm{Ci}$ (or $6.7 \mu \mathrm{Ci} / \mathrm{cm}^{3}$ ) cesium-137 in the liquid. The source strength used in the modeling of the tank wall was assumed to be $20 \mu \mathrm{Ci} / \mathrm{cm}^{3}$, per Energy Systems' recommendation. However, this value, which has not been verified with actual measurements, is larger by a factor of 3 than the assumed average cesium-137 concentration of $6.7 \mu \mathrm{Ci} / \mathrm{cm}^{3}$ in the tai $\mathrm{k}$ liquid.

\subsubsection{Geometry Input}

Figure 5 shows the model geometry used by the shielding codes to estimate the gamma exposure rates created by the liquid and sludge within the tank and in the tank wa!l. A cylindrical geometry 


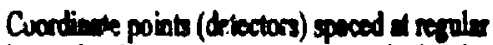

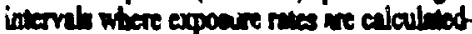

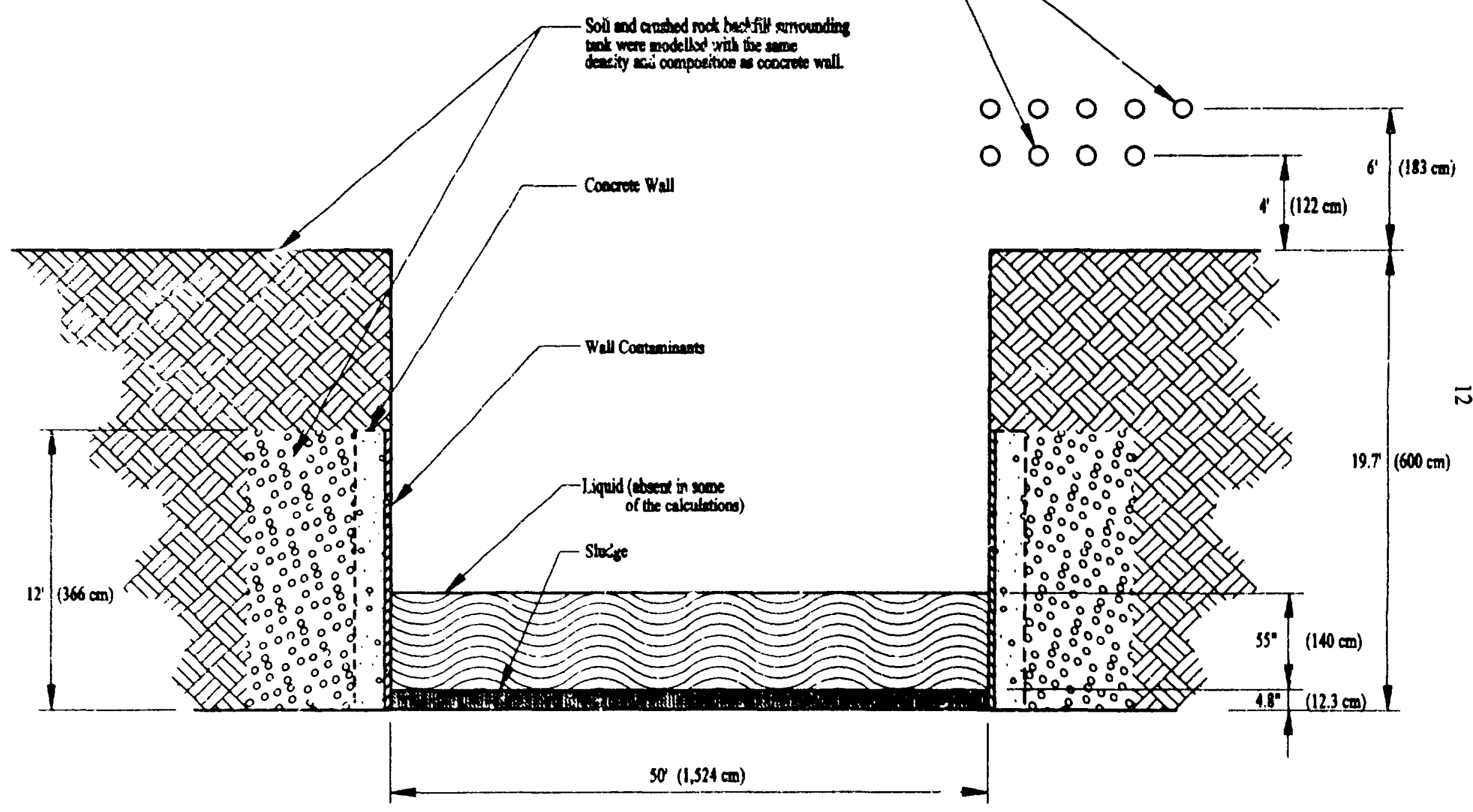

Fig. 5. Tank cross-section geometry used for the QAD-CGGP shielding code model, calculation set 1. (Drawing is not to scale.) 
was used to model the tanks and tank contents. The sl'1dge and liquid "solid cylinders" had depths of $4.8 \mathrm{in} .(12.3 \mathrm{~cm})$ and $55 \mathrm{in}$. $(139.7 \mathrm{~cm})$, respectively, and each had a radius of $25 \mathrm{ft}$.

There are $n$ ) field measurement data that identify the nature and extent of contaminant penetration in the tank walls. For the purpose of this calculation set, it is assumed that only the interior surface of the tank wall is radioactive, and that significant contamination has not been adsorbed deeper than 1 in. $(2.54 \mathrm{~cm})$ into the wall. It is further assumed that the contamination is uniform over the surface of the wall. Thus, the contamination in the tank wall was modeled as a cylindrical shell 1 in. thick and $12 \mathrm{ft}(365.76 \mathrm{~cm})$ high; multiplying the shell volume times the specific activity of $20 \mu \mathrm{Ci} / \mathrm{cm}^{3}$ gives a total loading for this shallow surface source of $89 \mathrm{Ci}$ cesium137.

The soil and crushed rock backfill surrounding the tank was assumed to be the same density and composition as the Gunite tank walls.

To calculate exposure rates outside of tank $W-10$, the collapsed residual dome material was assumed to provide no shielding of the gamma fields generated from the sources in the tank. Other tanks, buildings, or terrain were also assumed not to atteruate or shield exposures. It is assumed that the collapsed overburden does not increase the overall volume or height of the tank contents.

\subsubsection{Detector Input}

As defined for code input, detectors are the locations or coordinates of the points in space for which the code outpui (exposure rate) is calculated (see Fig. 5).

To estimate radiation exposure levels at waist and head height for a worker, exposure rates were calculated at code "detectors" at 4- $\mathrm{ft}$ and 6-ft elevations above the ground surface. The exposure rates were also calculated laterally out from the interior rim of the tank walls at approximately $1-\mathrm{ft}$ intervals to a distanco of $25 \mathrm{ft}$, and thereafter at distances of $50,75,100$, and $150 \mathrm{ft}$ from the tank rim.

The "water dose" buildup factor was selected for the code input to take into account the scattered component of the flux. The semiempirical buildup factor accounts for the increase (i.e.. buildup) in the flux density at some detector positions due to scattered gamma rays; the buildup factor is multiplied by the uncollided flux in the code to obtain the total flux (additional discussion on is buiidup provided in Appendix A).

\subsection{RESULTS AND ANALYSES}

Tables $2 \mathrm{a}$ and $2 \mathrm{~b}$ show exposure rates at $4-$ and 6 - $\mathrm{ft}$ elevations, respectively, calculated at 1 - $\mathrm{ft}$ intervals from the tank's interior edge out to a distance of $25 \mathrm{ft}$. Not all of the exposure rates calcuiated are listed in the tables, however; calculated exposure rates that are significantly below background exposure rates are not included. ISince nominal background for nonradiological areas is on the order of $50 \mu \mathrm{R} / \mathrm{h}$ (background ior the South Tank Farm is higher), values below about 10 $\mu \mathrm{R} / \mathrm{h}$ are not included in Tables $2 \mathrm{a}$ and $2 \mathrm{~b}$. For example, exposure rates for distances of $50 \mathrm{ft}$ and greater are not included because the calculated values are significantly below background.I 
Table 2a. Calculation set 1: exposure rates as a function of distance from tank edget to $25 \mathrm{n}$ (4-ntevation)

\begin{tabular}{|c|c|c|c|c|c|c|c|}
\hline \multirow[b]{2}{*}{ Distance $(\mathrm{f})$} & \multicolumn{7}{|c|}{ Exposure Rate (mR/b) } \\
\hline & $\begin{array}{l}\text { Sludge without } \\
\text { liquid shield }\end{array}$ & $\begin{array}{l}\text { Wall with sludge } \\
\text { shield" }\end{array}$ & $\begin{array}{l}\text { Sludge plus wail } \\
\text { (columns } 2+3 \text { ) }\end{array}$ & $\begin{array}{l}\text { Liquid } \\
\text { caly }\end{array}$ & $\begin{array}{l}\text { Sludge with } \\
\text { liquid shield }\end{array}$ & $\begin{array}{l}\text { Wall with sludge and } \\
\text { liquid shield }\end{array}$ & $\begin{array}{c}\text { Liquita plus sludge plus } \\
\text { wail columms } \\
5\end{array}$ \\
\hline 0 & $2.7 \mathrm{E}+04$ & $3.8 \mathrm{E}+02$ & $2.7 \mathrm{E}+04$ & $9.6 E+02$ & $1.3 \%$ & $370 \%+6$ & $13 E+03$ \\
\hline 1 & $2.4 \mathrm{E}+0.4$ & $3.1 E+02$ & $2.4 E+04$ & $8.0 E+02$ & T.5ista: & $2 . \alpha E+02$ & $1 ; \mathrm{F}+03$ \\
\hline 2 & $1.9 \mathrm{E}+04$ & $2.4 E+02$ & $1.9 E+04$ & $6.2 E+02$ & $1.5 \mathrm{ES}$ & $1.8 E+0$. & $3 . \ln : n$ \\
\hline 3 & $1.4 E+i 4$ & $2.0 E+02$ & $1.4 E+04$ & $4.6 E+02$ & $2.7 \mathrm{E}-\mathrm{U}_{\ldots}$ & $1.5 F+5$ & in ite 02 \\
\hline 4 & $1.0 E+04$ & $1.6 \mathrm{E}+02$ & $1.0 E+04$ & $3.3 \mathrm{E}+02$ & & :. $26 \cdot 0.02$ & $45 E+02$ \\
\hline 5 & $7.0 \mathrm{E}+03$ & $1.4 \mathrm{E}+02$ & $7.1 E+03$ & $2.4 E+02$ & & $1.1 \mathrm{E}+02$ & $3.5 \mathrm{E}+\sigma_{2}$ \\
\hline 6 & $4.6 \mathrm{E}+03$ & $1.2 \mathrm{E}+02$ & $4.7 \mathrm{E}+03$ & $1.6 \mathrm{E}+02$ & & $9.0 \mathrm{E}+01$ & $2.5 \mathrm{E}+02$ \\
\hline 7 & $2.8 E+03$ & $1.0 E+02$ & $2.9 E+03$ & $1.2 E+02$ & & $7.8 E+01$ & $1.9 E+02$ \\
\hline 8 & $2.1 E+03$ & $9.1 E+01$ & $2.2 E+03$ & $8.9 E+01$ & & $7.1 \mathrm{E}+01$ & $1.6 \mathrm{E} \div \mathrm{C2}$ \\
\hline 9 & $9.6 \mathrm{E}+02$ & 8.1E+01 & $1.0 \mathrm{E}+03$ & $5.8 E+01$ & & $6.4 \mathrm{E}+01$ & $1.2 \mathrm{E}+02$ \\
\hline 10 & $3.2 \mathrm{E}+02$ & $6.4 E+01$ & $3.8 E+02$ & $3.6 \mathrm{E}+01$ & & $5.2 E+01$ & $8.9 \mathrm{E}+01$ \\
\hline 11 & $2.8 \mathrm{E}+01$ & $5.7 E+01$ & $8.5 E+01$ & $2.0 \mathrm{E}+01$ & & $4.8 \mathrm{E}+01$ & $6.8 \mathrm{E}+01$ \\
\hline 12 & $7.5 E-01$ & $4.0 \mathrm{E}+01$ & 4. $1 E+01$ & $1.0 \mathrm{E}+01$ & & $3.8 \mathrm{E}+01$ & $4.8 E+01$ \\
\hline 13 & $1.4 \mathrm{E}-02$ & $3.4 \mathrm{E}+01$ & $3.4 \mathrm{E}+01$ & $3.6 E+\infty$ & & $3.3 E+01$ & $3.7 \mathrm{E}+01$ \\
\hline 14 & & $2.7 E+01$ & $2.7 \mathrm{E}+01$ & 4.1E-01 & & $2.6 \mathrm{E}+01$ & $2.6 E+01$ \\
\hline 15 & & $2.0 \mathrm{E}+01$ & $2.0 \mathrm{E}+01$ & $1.5 E-02$ & & $2.0 \mathrm{E}+01$ & $2.0 \mathrm{E}+01$ \\
\hline 16 & & $1.6 E+01$ & $1.6 \mathrm{E}+01$ & & & $1.6 \mathrm{E}+01$ & $1.6 \mathrm{E}+01$ \\
\hline 17 & & $1.4 \mathrm{E}+01$ & $1.4 E+01$ & & & $1.4 E+01$ & $1.4 \mathrm{E}+01$ \\
\hline 18 & & $8.9 E+\infty 0$ & $8.9 E+00$ & & & $8.9 \mathrm{E}+\infty$ & $8.9 E+\infty$ \\
\hline 19 & & $5.9 E+\infty 0$ & $5.9 E+\infty 0$ & & & $5.9 E+\infty 0$ & $5.9 E+\infty 0$ \\
\hline 20 & & $5.6 \mathrm{E}+\infty 0$ & $5.6 \mathrm{E}+00$ & & & $5.6 \mathrm{E}+\alpha$ & $5.6 E+00$ \\
\hline 21 & & $3.9 E+20$ & $3.9 E+.00$ & & & $3.9 E+00$ & $3.9 E+00$ \\
\hline 22 & & $3.5 E+\infty 0$ & $3.5 \mathrm{E}+00$ & & & $3.5 E+\infty$ & $3.5 E+00$ \\
\hline 23 & & $1.9 \mathrm{E}+\infty 0$ & $1.9 E+\infty 0$ & & & $1.9 E+\infty 0$ & $1.9 E+00$ \\
\hline 24 & & $2.4 E-01$ & $2.4 \mathrm{E}-01$ & & & $2.4 E-01$ & $2.4 \mathrm{E}-0 \mathrm{I}$ \\
\hline 25 & & $1.3 \mathrm{E}-02$ & $1.3 E-02$ & & & $1.3 \mathrm{E}-02$ & 1.3E-02 \\
\hline
\end{tabular}

-Sludge without liquid shield = Exposure rates in the sbsence of liquid to shield the ra tiation exposure fields generatod by sludge alone.

Wall with sludge shield = Exposure rates dwe to tank wall when liquid is not present in the tank; only the effoct of sludge shielding part of the tank wall is considered. Sludge does not contritute to the source term, but acts only as a shield.

Liquid only = Exposure rates due to liquid only.

'Sludge $w /$ liquid smicid = Exposure rates in the presence of a liquid layer that attenuates the radiation fields generated by the sludge. Liquid only acts an a shield and doen not contribute to the source term.

Wall with sludge and liquid shield = Exposure rates due to ta:ix wall when hoth liquid and sludge are present and act as shield to cover portions of the tank wall; no contribution to the source term. 
Table 2b. Calculation set 1: exposure rates as a function of distance from tank ede to 25 it (6-ft elevation)

\begin{tabular}{|c|c|c|c|c|c|c|c|}
\hline \multirow[b]{2}{*}{ Distance (ft) } & \multicolumn{7}{|c|}{ Exposure Rale (mR/h) } \\
\hline & $\begin{array}{l}\text { Sludge without } \\
\text { liquid shiekt" }\end{array}$ & $\begin{array}{l}\text { Wall with } \\
\text { sludge shield" }\end{array}$ & $\begin{array}{l}\text { Sludge plus wall } \\
\text { (columns } 2+3 \text { ) }\end{array}$ & Liquid only & $\begin{array}{l}\text { Sludge with } \\
\text { liquid shield }\end{array}$ & $\begin{array}{l}\text { Wall with sludge and } \\
\text { liquid shield }\end{array}$ & $\begin{array}{l}\text { Liquid plus sludge } \\
\text { plus wall } \\
\text { (columns } 5+6+7 \text { ) }\end{array}$ \\
\hline 0 & 2.5E+04 & $3.5 E+02$ & $2.5 E+04$ & $8.9 E+02$ & $1.2 E+\infty 0$ & 2.7E + & $1.2 E+03$ \\
\hline 1 & $2.3 E+04$ & $3.0 \mathrm{E}+02$ & $2.3 \mathrm{E}+04$ & $7.5 E+02$ & $7.5 \mathrm{E}-01$ & $2.2 \mathrm{E}+\infty 2$ & $1.0 E+03$ \\
\hline 2 & $2.0 \mathrm{E}+04$ & $2.5 E+02$ & $2.0 E+04$ & $6.7 E+U 2$ & $3.6 \mathrm{E}-01$ & $1.9 E+02$ & $8.6 E+02$ \\
\hline 3 & $1.7 E+04$ & $2.1 \mathrm{E}+02$ & $1.7 \mathrm{E}+04$ & $5.6 \mathrm{E}+02$ & $1.4 \mathrm{E}-01$ & $1.7 E+02$ & $7.3 \mathrm{E}+02$ \\
\hline 4 & $1.4 E+04$ & $1.8 E+02$ & $1.4 E+04$ & $4.5 E+02$ & 4.7E-O2 & $1.4 E+02$ & $5.9 E+02$ \\
\hline 5 & $1.1 E+04$ & $1.6 \bar{E}+02$ & $1.1 E+04$ & $3.7 \mathrm{E}+02$ & $1.2 \mathrm{E}-02$ & $1.2 \bar{E}+02$ & $4.9 \mathrm{E}+02$ \\
\hline 6 & $8.9 E+03$ & $1.5 E+\infty 2$ & $9.0 \mathrm{E}+03$ & $2.8 \mathrm{E}+02$ & & $1.1 \mathrm{E}+02$ & $3.9 \mathrm{E}+02$ \\
\hline 7 & $6.8 E+03$ & $1.3 E+02$ & $6.9 \mathrm{E}+03$ & $2.3 E+02$ & & $9.7 E+01$ & $3.2 \mathrm{E}+02$ \\
\hline 8 & $5.9 E+03$ & $1.2 E+02$ & $6.0 \mathrm{E}+03$ & $2.0 \mathrm{E}+02$ & & $9.0 E+01$ & $2.9 E+02$ \\
\hline 9 & $4.2 E+0 ?$ & $1.0 E+02$ & $4.3 E+03$ & $1.5 E+02$ & & $8.0 E+01$ & $2.3 E+C 2$ \\
\hline 10 & $3.2 \mathrm{E}+03$ & $9.2 E+01$ & $3.3 E+03$ & $1.2 \mathrm{E}+02$ & & $7.1 E+01$ & $1.9 \mathrm{E}+02$ \\
\hline 11 & $2.2 E+03$ & $8.4 E+01$ & $2.3 E+03$ & $8.8 E+01$ & & $6.4 E+01$ & $1.5 E+02$ \\
\hline$: 2$ & $1.5 E+03$ & $7.4 \mathrm{E}+01$ & $1.6 E+03$ & $6.9 E+01$ & & $5.9 E+01$ & $1.3 \mathrm{E}+\boldsymbol{\sigma 2}$ \\
\hline 13 & $8.8 E+02$ & $6.9 E+01$ & $9.5 E+02$ & $5.1 E+01$ & & $5.4 \mathrm{E}+01$ & $1.1 \mathrm{E}+02$ \\
\hline 14 & $4.6 E+02$ & $5.6 E+01$ & $S .2 E+02$ & $3.7 E+01$ & & $4.5 E+01$ & $8.2 E+01$ \\
\hline 15 & $1.8 \mathrm{E}+02$ & $5.4 E+01$ & $2.3 \mathrm{E}+02$ & $2.8 \mathrm{E}+01$ & & $4.4 E+01$ & $7.2 \mathrm{E}+01$ \\
\hline 16 & $2.4 \mathrm{E}+01$ & $4.9 E+01$ & $7.1 E+01$ & $1.8 \mathrm{E}+01$ & & $4.1 E+01$ & $5.9 E+01$ \\
\hline 17 & $9.8 \mathrm{E}-01$ & $3.6 \mathrm{E}+01$ & $3.7 \mathrm{E}+01$ & $1.2 \mathrm{E}+01$ & & $3.2 E+01$ & $4.4 E+01$ \\
\hline 18 & $2.6 \mathrm{E}-02$ & $3.2 E+01$ & $3.2 \mathrm{E}+01$ & $6.9 E+00$ & & $3.0 \mathrm{E}+01$ & $3.7 \mathrm{E}+01$ \\
\hline 19 & & $2.8 E+01$ & $2.8 \mathrm{E}+01$ & $3.4 E+00$ & & $2.7 \mathrm{E}+01$ & $.3 .0 E+01$ \\
\hline 20 & & $2.6 E+01$ & $2.6 \mathrm{E}+01$ & $1.0 E+\infty$ & & $2.5 E+01$ & $2.6 E+01$ \\
\hline 21 & & $1.9 E+01$ & $1.9 \mathrm{E}+01$ & $1.0 E-01$ & & $1.9 E+01$ & $1.9 \mathrm{E}+01$ \\
\hline 22 & & $1.5 E+01$ & $1.5 E+01$ & & & $1.5 E+01$ & $1.5 E+01$ \\
\hline $2 ?$ & & $1.5 E+01$ & $1.5 E+01$ & & & $1.5 E+01$ & $1.5 E+01$ \\
\hline 24 & & $1.2 \mathrm{E}+01$ & $1.2 \mathrm{E}+01$ & & & $1.2 E+01$ & $1.2 E+01$ \\
\hline 25 & & $1.1 E+01$ & $1.1 E+01$ & & & $1.1 E+01$ & $1.1 E+01$ \\
\hline
\end{tabular}

-Sludge without liquid shield = Exposure rates in the absence of liquid to shield the radiation exposure fields generated by sludge alone.

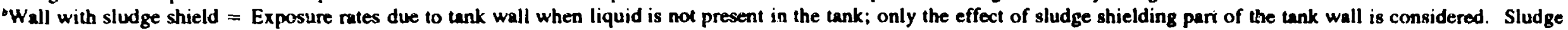
does not contribute to the source term, but acts only as a shield.

Liquid oaly = Exposure rates due to liquid only.

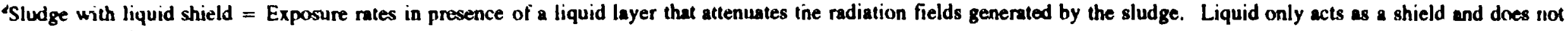
contribute to the source term.

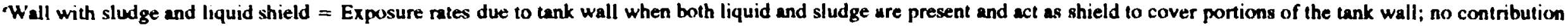
to the source term. 
The tables each contain eight columns of data:

Column 1: Lateral distance ( $\mathrm{ft}$ ) out from the edge of the tank.

Column 2: Exposure rates for a sludge source with no overlying layer of liquid present.

Column 3: Exposure rates for a 1-in.-deep tank wall source, the bottom -5 in. of which is covered by a sludge shield.

Column 4: Total exposure rates for a combined source of sludge and tank wall (Column 2 results plus Column 3 results).

Column 5: Exposure rates for a liquid-only source.

Column 6: Exposure rates for a sludge source with an overlying liquid (non-source) layer that absorbs some of the gamma energy emitted from the sludge.

Column 7: Exposure rates for a 1-in.-deep tank wall source, the bottom $\sim 60$ in. of which is covered by liquid and sludge layers.

Column 8: Total exposure rate for a combined source of sludge, liquid, and tank wall (Column 5 results plus Column 6 results plus Column 7 results).

The information in Tables $2 a$ and $2 b$ is presented graphically in Fig. 6. Relevant observations are summarized below.

For the combined sludge-plus-wall source (Figs. $6 a$ and $6 c$ ):

- The total exposure rates calculated at the tank edge are $27,000 \mathrm{mR} / \mathrm{h}$ at a $4-\mathrm{ft}$ height, and 25,000 $\mathrm{mR} / \mathrm{h}$ at a $6-\mathrm{ft}$ height.

- At $25 \mathrm{ft}$ from the tank edge, the total exposures drop approximately 6 orders of magnitude to $0.013 \mathrm{mR} / \mathrm{h}$ at a $4-\mathrm{ft}$ height, and approximately 3 orders of magnitude to $11 \mathrm{mR} / \mathrm{h}$ at a $6-\mathrm{ft}$ height. Exposure rates at the 4- $\mathrm{ft}$ elevation decrease more rapidly as a funcilon of distance from the tank edge than those at the $6-\mathrm{ft}$ elevation because gamma rays must pass through slightly more attenuating material to reach the 4 -ft-high detector than the 6 - $\mathrm{ft}$-high detector due to the geometry.

- Because of its relatively high activity, the sludge is the principal contributor to the exposure rates out to approximately $10 \mathrm{ft}$ from the tank edge for the 4-ft elevation, or out to approximately $16 \mathrm{ft}$ from the tank edge for the $6-\mathrm{ft}$ elevation. Beyond 10 or $16 \mathrm{ft}$, respectively, the tank waii axposure rate contribution dominatcs. The reason for this is that as the detector moves away trom the tank edge, the gammas must pass through more and more of the surrounding soil to reach the detector. The average path length (or line-of-sight distance) of the gammas through the : Irrounding soil is greater for the sludge than for the tank wall because the sludge layer is farther below the ground surface. Since gamma attenuation increases exponentially with path length, a tradesff is eventually reached where the greater pati length and more severe attenuation of the sludge gammas offset the larger sludge source strength, and the tank wall becomes the principal exposure rate contributor.

For the combined sludge-plus-liquid-plus-wall source (Figs. $6 \mathrm{~b}$ and $6 \mathrm{~d}$ ):

- The total expostre rates calculated at the tank edge are $1300 \mathrm{mR} / \mathrm{h}$ at a $4-\mathrm{ft}$ height, and 1200 $\mathrm{mR} / \mathrm{h}$ at a $6-\mathrm{ft}$ height. 
6a. Source: Sludge and Tank Wall ( 4 ft elevation; see Table 2a)

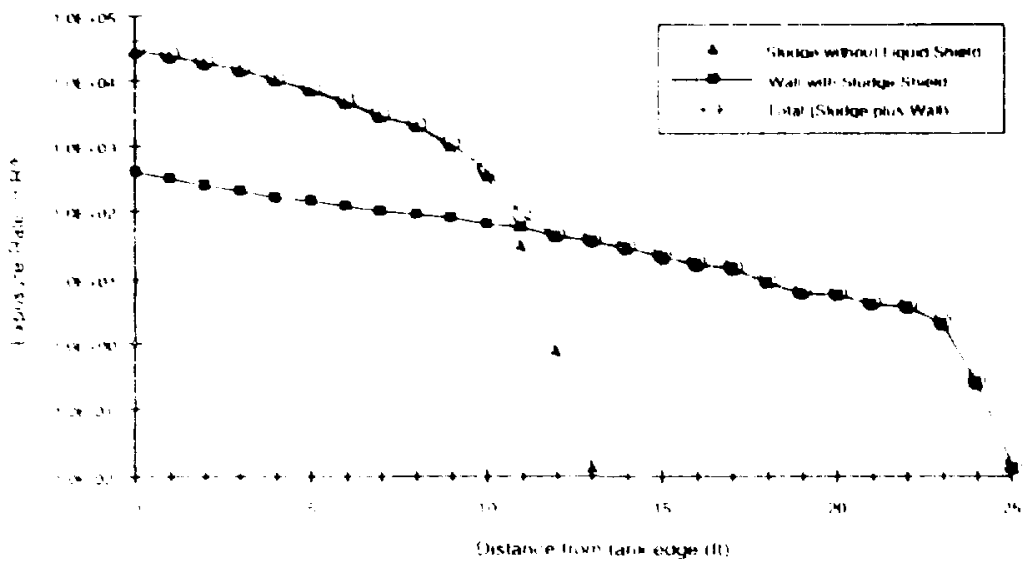

6b. Source: Sludge, Liquild, and Tank Wall (4 ft elevation; see Table 2a)

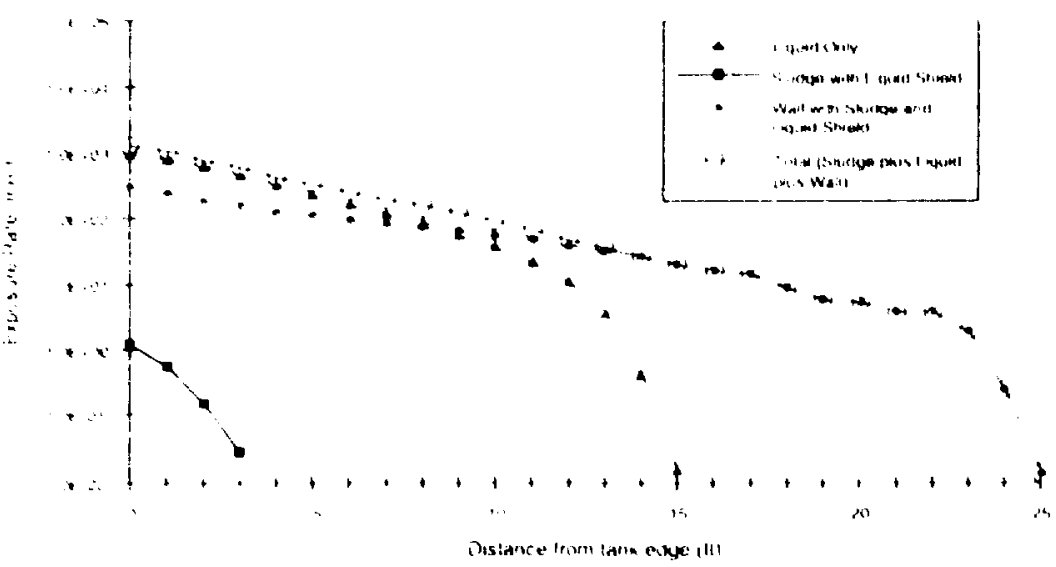

6c. Source: Sludge and Tank Wall

(6 Il elevation; see Table $2 b$ )

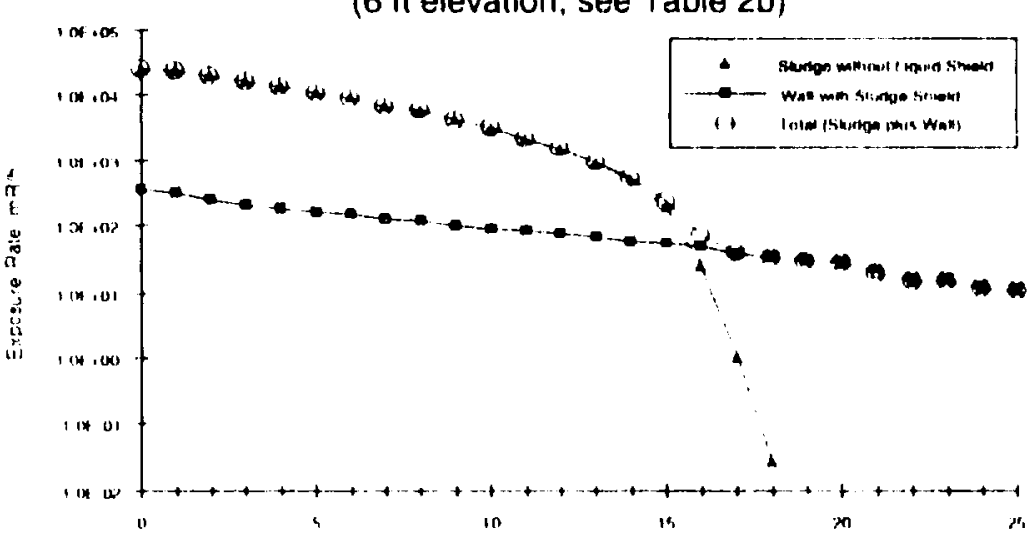

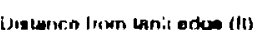

6d. Source: Sludge, Liquid, and Tank Wall (6 ft elevation; see Table 2b)

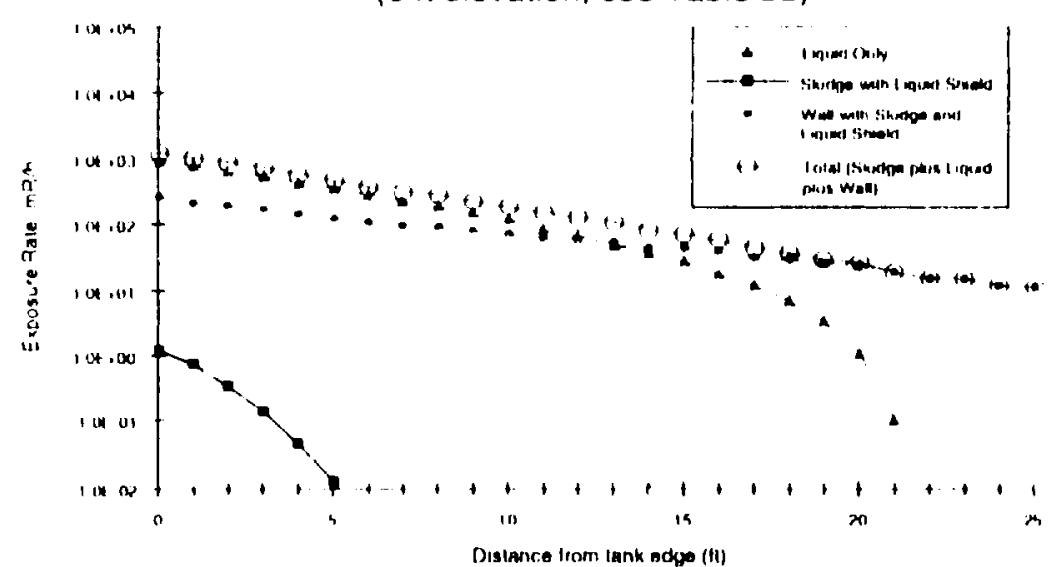


- At $25 \mathrm{ft}$ from the tank edge, the total exposures drop approximately 5 orders of majnitude to $0.013 \mathrm{mR} / \mathrm{h}$ at a $4-\mathrm{ft}$ height, and approximately 2 orders of magnitude to $11 \mathrm{mR} / \mathrm{h}$ at a $6-\mathrm{ft}$ height.

- The liquid makes a slightly greater contribution to the total exposure rate than the tank wall out to a distance of $8 \mathrm{ft}$ for the $4-\mathrm{ft}$ elevation, or out to a distance of $12 \mathrm{ft}$ for the $6-\mathrm{ft}$ elevation. Bayuis 8 or $12 \mathrm{ft}$, respectively, the tank wall contribution dominates. The unattenuated radiation exposure fields generated by the tank wall are not as high as those frem the sludge or liquid, but the wall-generated fields do not diminish as fast with increasing distance as the sludge or liquid fields because of the comparatively shorter path lengths traveled by the wall-generated gammas through the surrounding soil.

- Comparison of individual exposure rates due to sludge (uncovered) and sludge covered with a liquid shield shows that although the liquid is contaminated and produces an exposure field of its own, it provides valuable shielding for the fields created by the radiunuclide consituents in the sludge. Exposure rates at the tank edge for the uncovered sludge source are approximately 20 times greater than those for the sludge source covered with a liquid shield.

Figure 7 shows total exposure rates at specific distance contours for 4-ft and 6-ft elevations due to the following combined sources: (1) radioactive sludge (with no liquid shield cover) plus radioactive contaminants in the tank wall, and (2) radioactive sludge plus radioactive liquid plus radioactive contaminants in the tank wall. Distance contours are shown in S-ft intervals out to 25 $\mathrm{ft}$, then in 25 - $\mathrm{ft}$ intervals out to $100 \mathrm{ft}$, and then at $150 \mathrm{ft}$.

\section{CALCULATION SET 2: EXPOSURE RATES ABOVE THE TANK}

This calculation set estimates exposure rates above the tank as a function of distance from the tank center out to a total radius of $25 \mathrm{ft}$ (tank edge), at heights of $4 \mathrm{ft}$ and $6 \mathrm{ft}$ above a hypothetical working platform situated above the tank.

\subsection{ASSUMPTIONS AND CODE INPUT}

Figure 8 shows the geometry used for the QAD-CGGP shielding code model. The geometry is similar to that used for calculation set 1 but with the addition of a work platform with a walkirg surface approximately $5 \mathrm{ft}$ above ground surface. The work platform is assumed to be invisible to (i.e., does not attenuate) ganıma rays emanating from the tank during the hypothetical accident.

To estimate radiation exposure levels at waist and head height for a worker on the platform, exposure rates were calculated at 4-ft and 6-ft elevations from the top of the platform's walking surface. Exposure rates were estimated at approximately $3.3-\mathrm{ft}(1-\mathrm{m})$ intervals from the platform center to the edge. The platform was assumed to be staged such that the tank and platform centerlines were coincident; therefore, exposure rate profiles are symmetric about the platform centerline. 


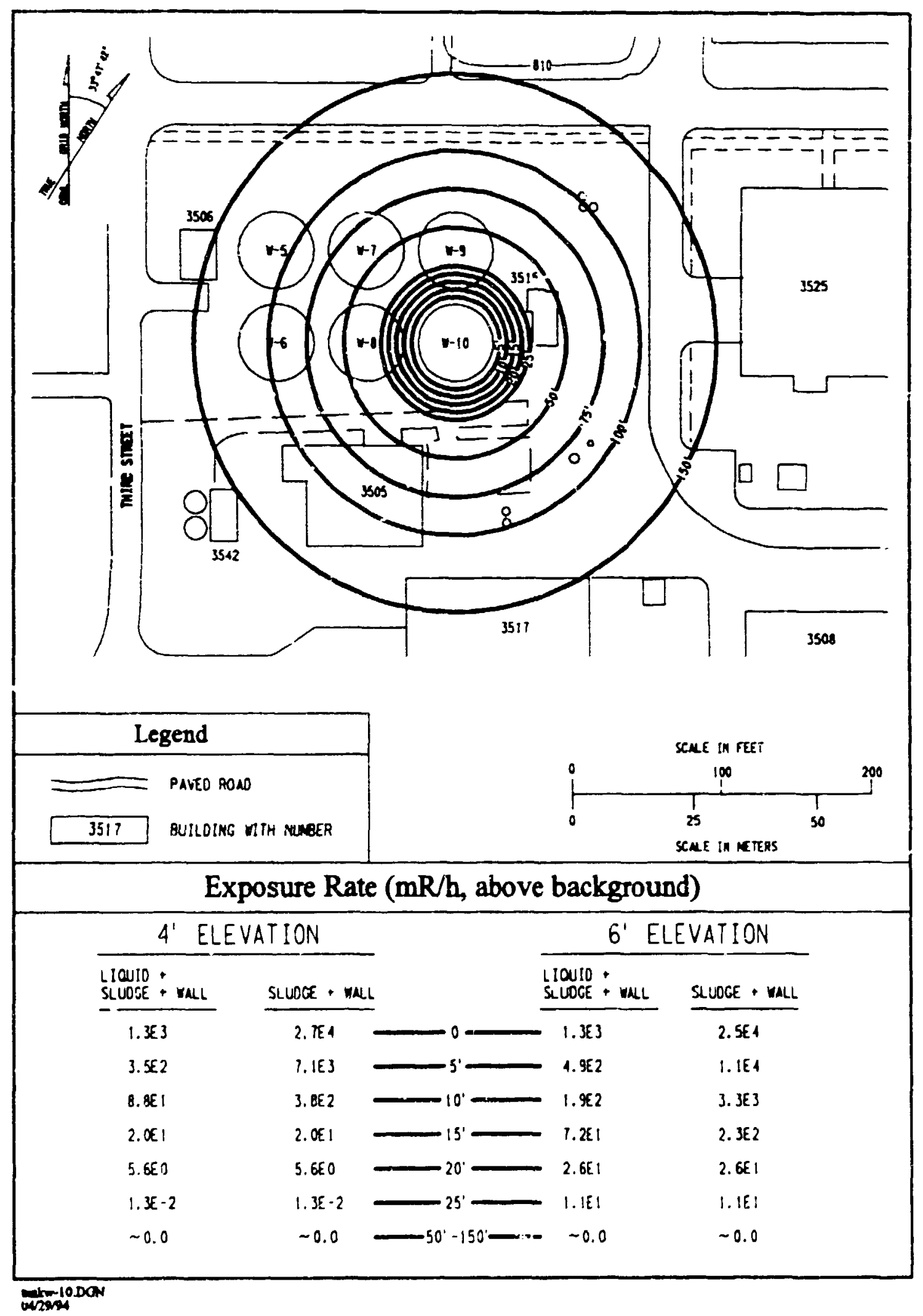

Fig. 7. Exposure rates ambind tank W.10 at various distances from tank edge, calculation set 1. 


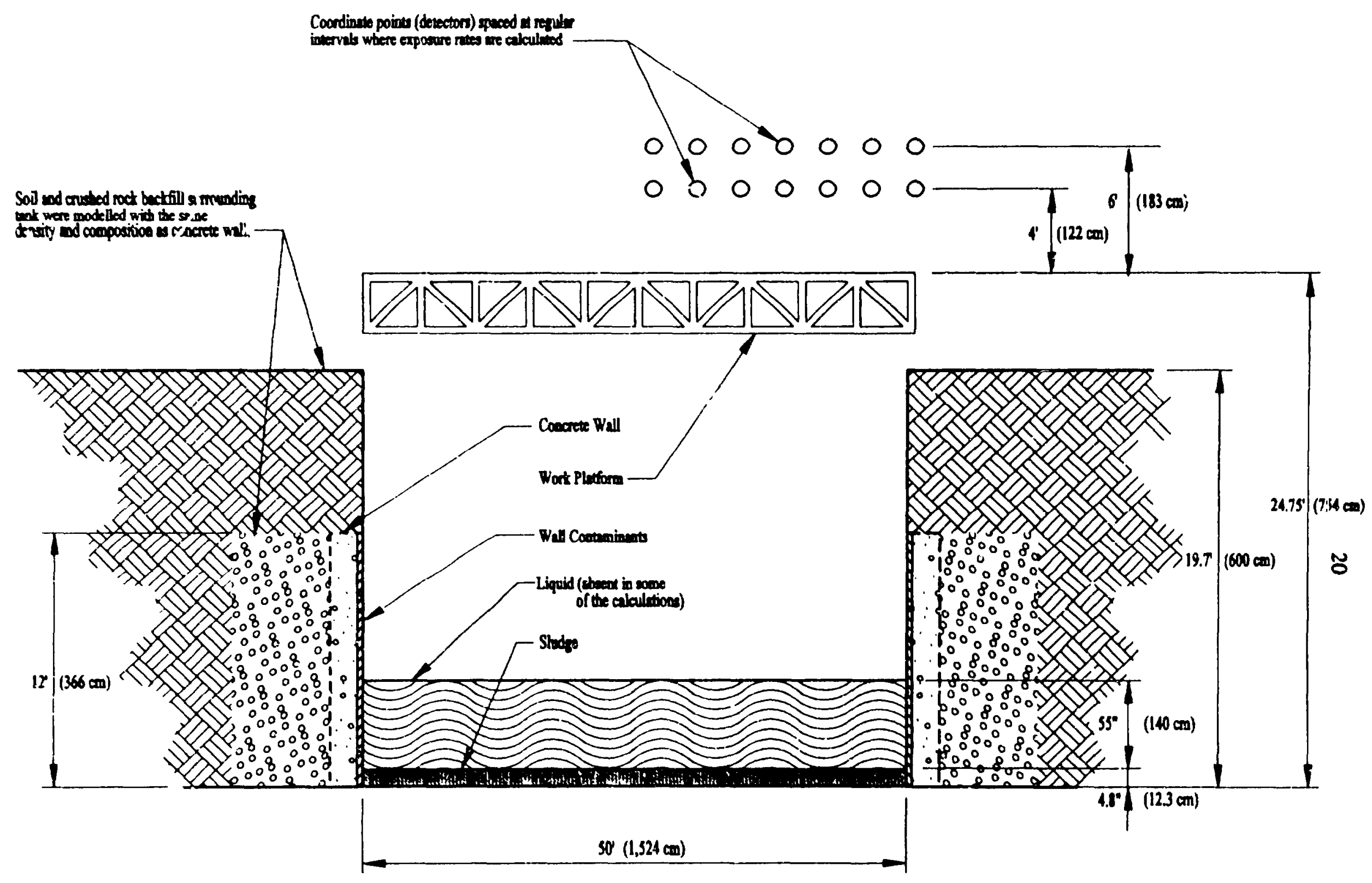

Fig. 8. Tank cross-section geometry used for the QAD-CGGP shielding code model, calculation set 2. (Drawing is not to scale.) 


\subsection{RESULTS AND ANALYSES}

Tables $3 \mathrm{a}$ and $3 \mathrm{~b}$ show exposure rates at 4 and 6-ft elevations above ine working platform, respectively, calculated at 3.3-ft (1-m) intervals from the platform's centerlixe to the tank' 3 interior rim (a radial distance of $25 \mathrm{ft}$ ). As in calculation set 1 , each table contains columns of exposure rate data for individual and combined sources.

The information in Tables $3 \mathrm{a}$ and $3 \mathrm{~b}$ is presented graphically in Fig. 9; as shown, little variation in exposure rates is manifest from the center to the edge of the tank platform and even less between data for the 4-ft and 6-ft elevations. Other relevant observations are summarized beiow.

For the combined sludge-plus-wall source (Figs. 9a and 9c):

- The total exposure rates calculated at the platform center are $32,000 \mathrm{mR} / \mathrm{h}$ at a 4 -ft height, and $29,000 \mathrm{mR} / \mathrm{h}$ at a $6-\mathrm{ft}$ height.

- At a radial distance of $25 \mathrm{ft}$ from the platform center, which vertically coincides with the tank edge, the total exposure rates drop only slightly $t 022,000 \mathrm{mR} / \mathrm{h}$ at a $4-\mathrm{ft}$ height, and to 21,000 $\mathrm{mR} / \mathrm{h}$, at a 6 -ft height.

- Because of its relatively high specific activity, sludge is the principal contributor to exposure rates at all detector positions. The sludge contribution is greater by a factor of 58 to 76 than the tank wall contribution.

For the combined sludge-plus-liquid-plus-wall source (Figs. 9b and 9d):

- The total exposure rates calculated at the tank edge are $1700 \mathrm{mR} / \mathrm{h}$ at a $4-\mathrm{ft}$ height, and 1600 $\mathrm{mR} / \mathrm{h}$ at $26-\mathrm{ft}$ height.

- At a radial distance of $25 \mathrm{ft}$ from the platform center, the tocal exposure rates drop only slightly to $1000 \mathrm{mR} / \mathrm{h}$ at a $4-\mathrm{ft}$ height, and to $960 \mathrm{mR} / \mathrm{h}$ at a $6-\mathrm{ft}$ height.

- The liquid provides a greater share (75 to 80\%) of the total exposure rates than either the tank wall or the sludge at al! detector positions. The liquid contribution is greater by a factor of 3.2 to 3.6 than the tank wall contribution, and more than 2 orders of magnitude greater than the sludge contribution. As in calculation sec 1 , these results demonstrate the significant shielding effect of the liquid layer on the gamma fields created by the sludge contaminants.

\section{CALCUlation SET 3: EXPOSURE RATE IN BUILDING 150 FT AWAY}

This cisiulation set estimates the exposure rate at a location $150 \mathrm{ft}$ from the tank edge, at a height of $20 \mathrm{ft}$ above the ground, in an attempt to model the possible direct gamma exposure rate to a person on tise second floor of a hypnthetical building $150 \mathrm{ft}$ north of tank $\mathrm{W}-10$. With the exception of detector placement, code input for this caiculation set was identical to that for calculation set 1 . 
Table 3a. Calculation set 2: exposure rates as a function of distance from tank platform center to tank edge (4-ft elevation)

\begin{tabular}{|c|c|c|c|c|c|c|c|}
\hline \multirow[b]{2}{*}{ Distance (A) } & \multicolumn{7}{|c|}{ Exposure Rate $(\mathrm{mR} / \mathrm{h})$} \\
\hline & $\begin{array}{l}\text { Sludge without } \\
\text { liquid shieid' }\end{array}$ & $\begin{array}{l}\text { Wall with } \\
\text { sludge } \\
\text { shield }\end{array}$ & $\begin{array}{l}\text { Sludge plus wall } \\
\text { (colimns } 2+3 \text { ) }\end{array}$ & $\begin{array}{l}\text { Liquid } \\
\text { onlye }\end{array}$ & $\begin{array}{c}\text { Sludge with } \\
\text { liquid } \\
\text { shield }\end{array}$ & $\begin{array}{l}\text { Wall with } \\
\text { sludge and } \\
\text { liquid shield" }\end{array}$ & $\begin{array}{c}\text { Liquid plus sludge } \\
\text { plus wall } \\
\text { (columns } 5+6+7 \text { ) }\end{array}$ \\
\hline 0.00 & $3.2 E+04$ & $5.3 E+02$ & $3.2 E+04$ & $1.3 E+03$ & $2.7 E+\infty 0$ & $4.0 \mathrm{E}+02$ & $1.7 E+03$ \\
\hline 3.28 & $3.1 E+04$ & $5.3 \mathrm{E}+02$ & $3.2 \mathrm{E}+04$ & $1.3 E+0.3$ & $2.7 \mathrm{E}+\infty 0$ & $4.1 E+02$ & $1.7 \mathrm{E}+03$ \\
\hline 6.56 & $3.1 E+04$ & $5.3 \mathrm{E}+02$ & $3.1 E+04$ & $1.3 E+03$ & $2.6 \mathrm{E}+\infty 0$ & 4.1E+02 & $1.7 \mathrm{E}+03$ \\
\hline 9.84 & $3.0 \mathrm{E}+04$ & $5.3 E+.02$ & $3.0 \mathrm{E}+04$ & $1.2 E+03$ & $2.5 \mathrm{E}+00$ & 4.1E+02 & $1.6 \mathrm{E}+03$ \\
\hline 13.12 & $2.9 \mathrm{E}+04$ & $5.2 \mathrm{E}+02$ & $2.9 E+04$ & $1.2 E+03$ & $2.4 E+\infty 0$ & $4.1 E+02$ & $1.6 E+03$ \\
\hline 16.40 & $2.7 \mathrm{E}+04$ & $5.1 E+02$ & $2.8 E+04$ & $1.1 E+03$ & $2.2 \mathrm{E}+00$ & $4.0 \mathrm{E}+02$ & $1.5 E+03$ \\
\hline 19.68 & $2.5 E+04$ & $4.8 E+02$ & $2.6 \mathrm{E}+04$ & $9.7 E+02$ & $1.8 \mathrm{E}+00$ & $3.8 E+02$ & $1.4 \mathrm{E}+03$ \\
\hline 22.96 & $2.3 E+04$ & $4.0 \mathrm{E}+02$ & $2.4 \mathrm{E}+04$ & $8.7 E+02$ & $1.4 E+00$ & $3.1 E+02$ & $1.2 E+03$ \\
\hline 25.00 & $2.2 \mathrm{E}+04$ & $2.9 E+02$ & $2.2 E+04$ & $8.0 E+02$ & $1.2 \mathrm{E}+00$ & $2.3 E+02$ & $1.0 \mathrm{E}+03$ \\
\hline
\end{tabular}

- Sludge without liquid shield = Exposure rates in the absence of liquid to shield the radiation exposure fields generated by sludge alone. 'Wall with sludge shield = Exposure rates due to tank wall when liquid is not present in the tank; only the effect of sludge shielding part of the tank wall is considered. Sludge does not contribute to the source term, but acts only as a shield.

'Liquid only $=$ Exposure rates due to liquid only.

'Sludge with liquid shield = Exposure rates in the presence of a liquid layer that attenuates the radiation fields generated by the sludge. Liquid only acts as a shield and does not cuntribute to the source term.

Wall with sludge and liquid shield = Exposure rates due to tank wall when both liquid and sludge are present and act as strield to cover portions of the tank wall; no contribution to the source term. 
Table 3b. Calculation set 2: exposure rates as a function of distance from tank platform center to tank edge (6-ft elevation)

\begin{tabular}{c|ccc|cccc}
\hline & \multicolumn{9}{|c}{ Exposure Rate (mR/h) } \\
\hline $\begin{array}{c}\text { Distance } \\
\text { (ft) }\end{array}$ & $\begin{array}{c}\text { Sludge without } \\
\text { liquid shield }\end{array}$ & $\begin{array}{c}\text { Wall with } \\
\text { sludge } \\
\text { shield }\end{array}$ & $\begin{array}{c}\text { Sludge plus wall } \\
\text { (columns } 2+3)\end{array}$ & $\begin{array}{c}\text { Liquid } \\
\text { onlyc }\end{array}$ & $\begin{array}{c}\text { Sludge with } \\
\text { liquid shield }\end{array}$ & $\begin{array}{c}\text { Wall with } \\
\text { sludge and } \\
\text { liquid shield }\end{array}$ & $\begin{array}{c}\text { Liquid plus sludge } \\
\text { plus wall } \\
\text { (columns } 5+6+7 \text { ) }\end{array}$ \\
\hline 0.00 & $2.9 \mathrm{E}+04$ & $4.9 \mathrm{E}+02$ & $2.9 \mathrm{E}+04$ & $1.2 \mathrm{E}+03$ & $2.7 \mathrm{E}+00$ & $3.7 \mathrm{E}+02$ & $1.6 \mathrm{E}+03$ \\
3.28 & $2.8 \mathrm{E}+04$ & $4.9 \mathrm{E}+02$ & $2.9 \mathrm{E}+04$ & $1.2 \mathrm{E}+03$ & $2.6 \mathrm{E}+00$ & $3.7 \mathrm{E}+02$ & $1.6 \mathrm{E}+03$ \\
6.56 & $2.8 \mathrm{E}+04$ & $4.8 \mathrm{E}+02$ & $2.8 \mathrm{E}+04$ & $1.2 \mathrm{E}+03$ & $2.6 \mathrm{E}+00$ & $3.7 \mathrm{E}+02$ & $1.5 \mathrm{E}+03$ \\
9.84 & $2.7 \mathrm{E}+04$ & $4.8 \mathrm{E}+02$ & $2.8 \mathrm{E}+04$ & $1.1 \mathrm{E}+03$ & $2.5 \mathrm{E}+00$ & $3.7 \mathrm{E}+02$ & $1.5 \mathrm{E}+03$ \\
13.12 & $2.6 \mathrm{E}+04$ & $4.8 \mathrm{E}+02$ & $2.6 \mathrm{E}+04$ & $1.1 \mathrm{E}+03$ & $2.3 \mathrm{E}+00$ & $3.7 \mathrm{E}+02$ & $1.4 \mathrm{E}+03$ \\
16.40 & $2.5 \mathrm{E}+04$ & $4.6 \mathrm{E}+02$ & $2.5 \mathrm{E}+04$ & $9.8 \mathrm{E}+02$ & $2.1 \mathrm{E}+00$ & $3.6 \mathrm{E}+02$ & $1.3 \mathrm{E}+03$ \\
19.68 & $2.3 \mathrm{E}+04$ & $4.3 \mathrm{E}+02$ & $2.4 \mathrm{E}+04$ & $9.0 \mathrm{E}+02$ & $1.8 \mathrm{E}+00$ & $3.4 \mathrm{E}+02$ & $1.2 \mathrm{E}+03$ \\
22.96 & $2.1 \mathrm{E}+04$ & $3.5 \mathrm{E}+02$ & $2.2 \mathrm{E}+04$ & $8.0 \mathrm{E}+02$ & $1.4 \mathrm{E}+00$ & $2.8 \mathrm{E}+02$ & $1.1 \mathrm{E}+03$ \\
$25.5 \mathrm{~N}$ & $2.0 \mathrm{E}+04$ & $2.7 \mathrm{E}+02$ & $2.1 \mathrm{E}+04$ & $7.4 \mathrm{E}+02$ & $1.2 \mathrm{E}+00$ & $2.1 \mathrm{E}+02$ & $9.6 \mathrm{E}+02$ \\
\hline
\end{tabular}

-Sludge without liquid shield = Exposure rates in the absence of liquid to hield the radiation exposure fields generated by sludge alone. Wall with sludge shield = Exposure rates due to tank wall when liquid is not present in the tark; only the effect of sludge shielding part of the tank wall is sonsidered. Sludge does not contribute to the source term, but acts only as a shield.

'Liquid only $=$ Exposure rates due to liquid only.

¿Sludge with liyuid shield = Exposure rates in the presence of a liquid layer that attenuates the radiation fields generated by the sludge. Liquid only acts as a shield and does not contribute to the source term.

Wall with sludge and liquid shield = Exposure rates due to tank wall when both liquid and sludge are present and act as shield to cover portions of the tank wall; no contribution to the source term. 
8a. Source: Sludge and Tank Wall (4 It elevation; see Table 2a)

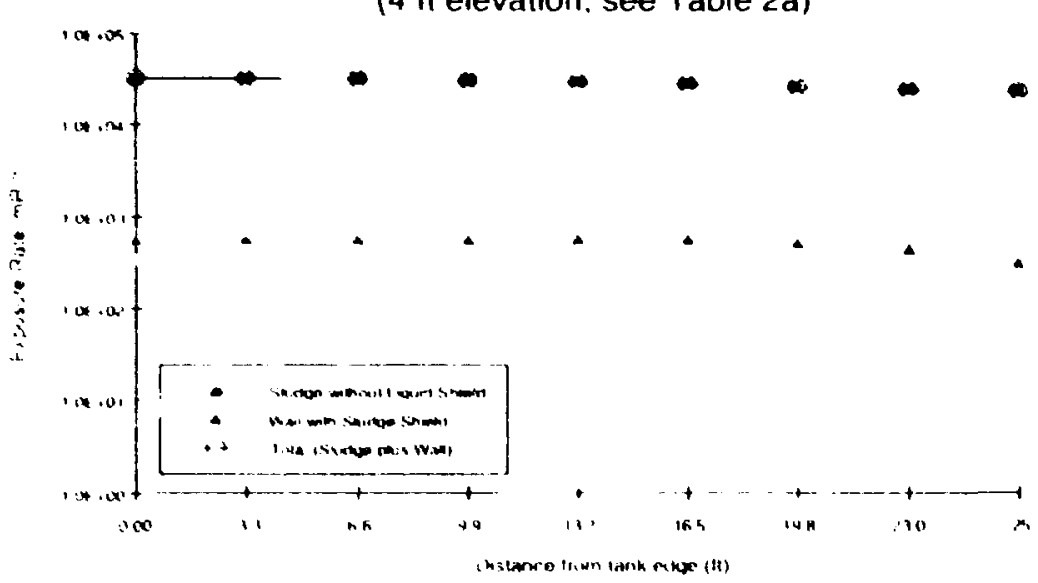

8t. Source: Sludge, Liquid, and Tank Wall (4 fl elevation, see Table $2 a$ )

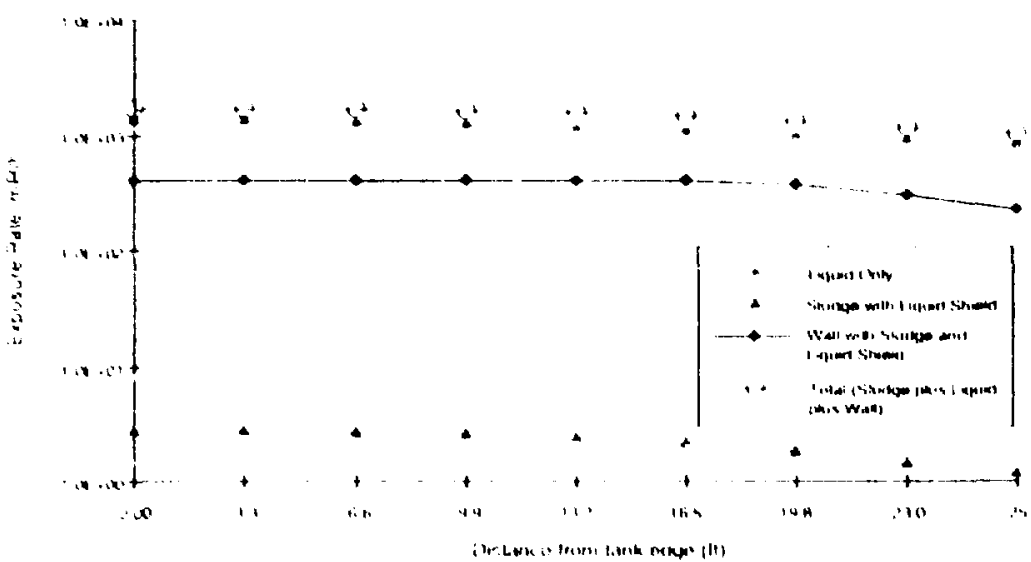

8c. Source: Sludge and Tank Wall

(6 th elevation; see Table 2b)

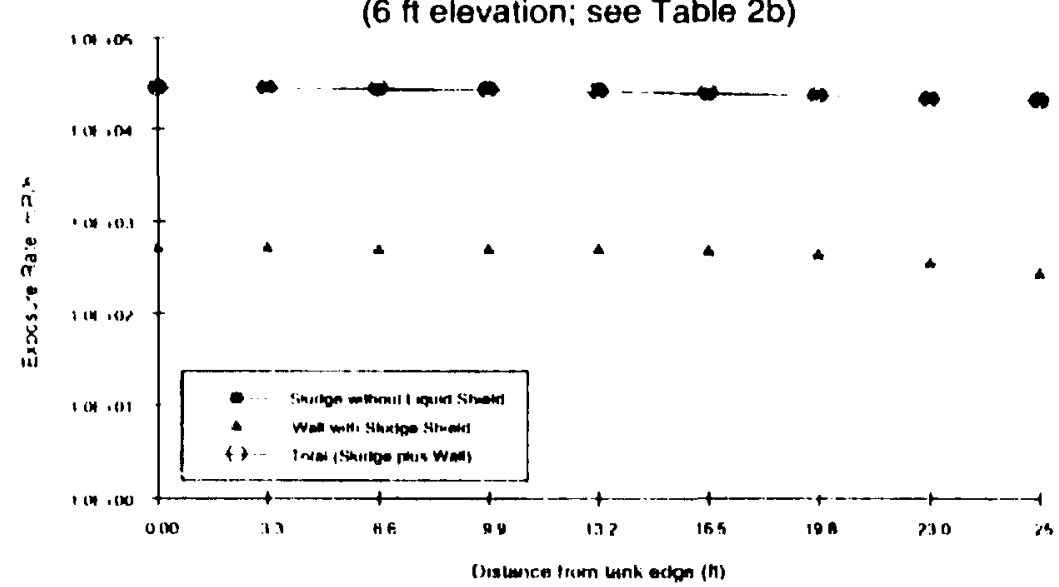

8d. Source: Sludge, Liquid, and Tank Wall (6 II elevation; see Table 2b)

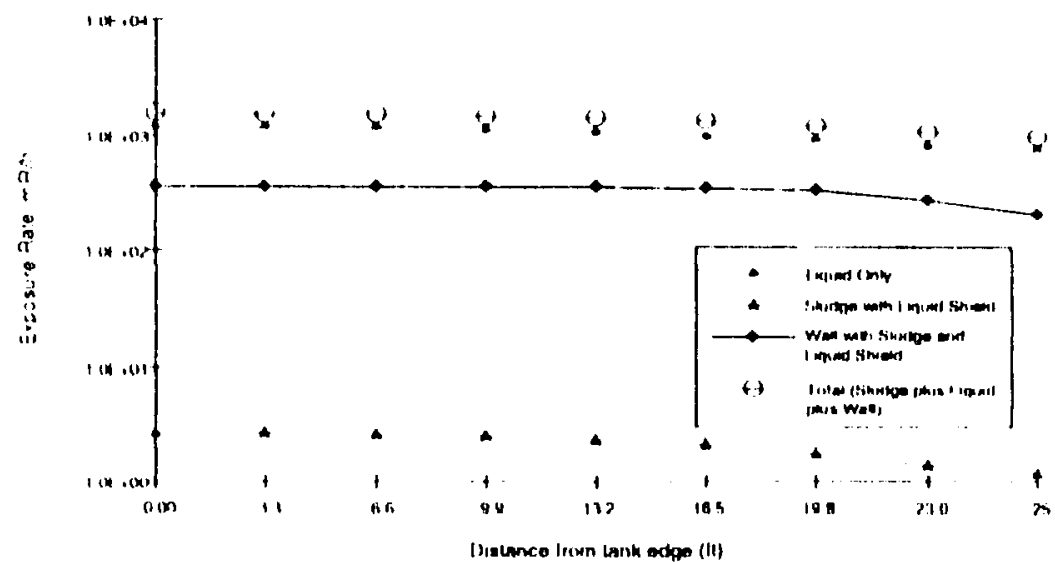


The exposure rates calculated in this set were insignificant (close to zero); no significant changes in local area background would be expected from direct exposure resulting from the hypothetical dome collapse modeled in this document.

\section{CALCULATION SET 4: \\ TOTAL EXPOSURES FOR TWO WORKER RESPONSE SCENARIOS}

Using the exposure rates from calculation sets 1 and 2, this calculation set computes tota! gamma radiation exposures for two hypothetical worker exposure scenarios: (1) the "investigator" scenario, where a worker is attracted by the accident-generated noise of a dome collapse but quickly leaves the area after noting the extent of the damage; and (2) the "fugitive" scenario, where a worker who is on the platform above the tank when the accident occurs flees the immediate area.

\subsection{ASSUMPTIONS}

As mentioned, two different exposure scenarios (i.e., unplanned occurrences) were considered for this study:

- The investigator scenario (see Fig. 10). A person working $16 \mathrm{ft}$ from the tank edge investigates the accident-generated noise by (a) approaching the tank edge, (b) viewing the damage for a set period of time while standing at the tank edge, and then (c) quickly returning to the original location $16 \mathrm{ft}$ from the tank edge. Exposure estimates performed for this scenario were divided into three cases. In each case, a worker travels (at $1 \mathrm{ft} / \mathrm{s}$ ) from a location $16 \mathrm{ft}$ away to the edge of the tank and back; the difference among the cases is the length of the investigation period $(10,20$, and 30 seconds).

- The fugirive scenario (see Fig. 11). A person is on the tank work platform when the hypothetical accident occurs. The person is assumed to leave the platform using the longest path (from one side to the other) and subsequently travel to a point $16 \mathrm{ft}$ from the tank edge. The person moves to this location at an assumed travel rate of $3.28 \mathrm{ft} / \mathrm{s}(1 \mathrm{~m} / \mathrm{s})$ on the platform and $1 \mathrm{ft} / \mathrm{s}$ on the ground.

These worst-casc scenarios are provided as only two of many possible exposure situations that could be studied. It is important to note at the outset that any discussion of the investigator and fugitive scenarios as outlined above is not meant to imply that the scenarios are considered either likely to occur or reasonably realistic. The South Tank Farm area is considered a radiation area and is roped off and restricted. The closest distance from the rope to the edge of tank W-10 is approximately $50 \mathrm{ft}$, and results of the modeling indicate that exposure rates drop to area background between $25 \mathrm{ft}$ and $50 \mathrm{ft}$. Personnel entering the area are trained radiation workers being monitored under Department of Energy (DOE) regulations, and radiation workers are trained to minimize their exposure in the event of an accident or an emergency situation.

With regard to the investigator scenario, it is considered unlikely that a trained radiation worker would move in the direction of the dome-collapse noise knowing that significant radioactive fields 


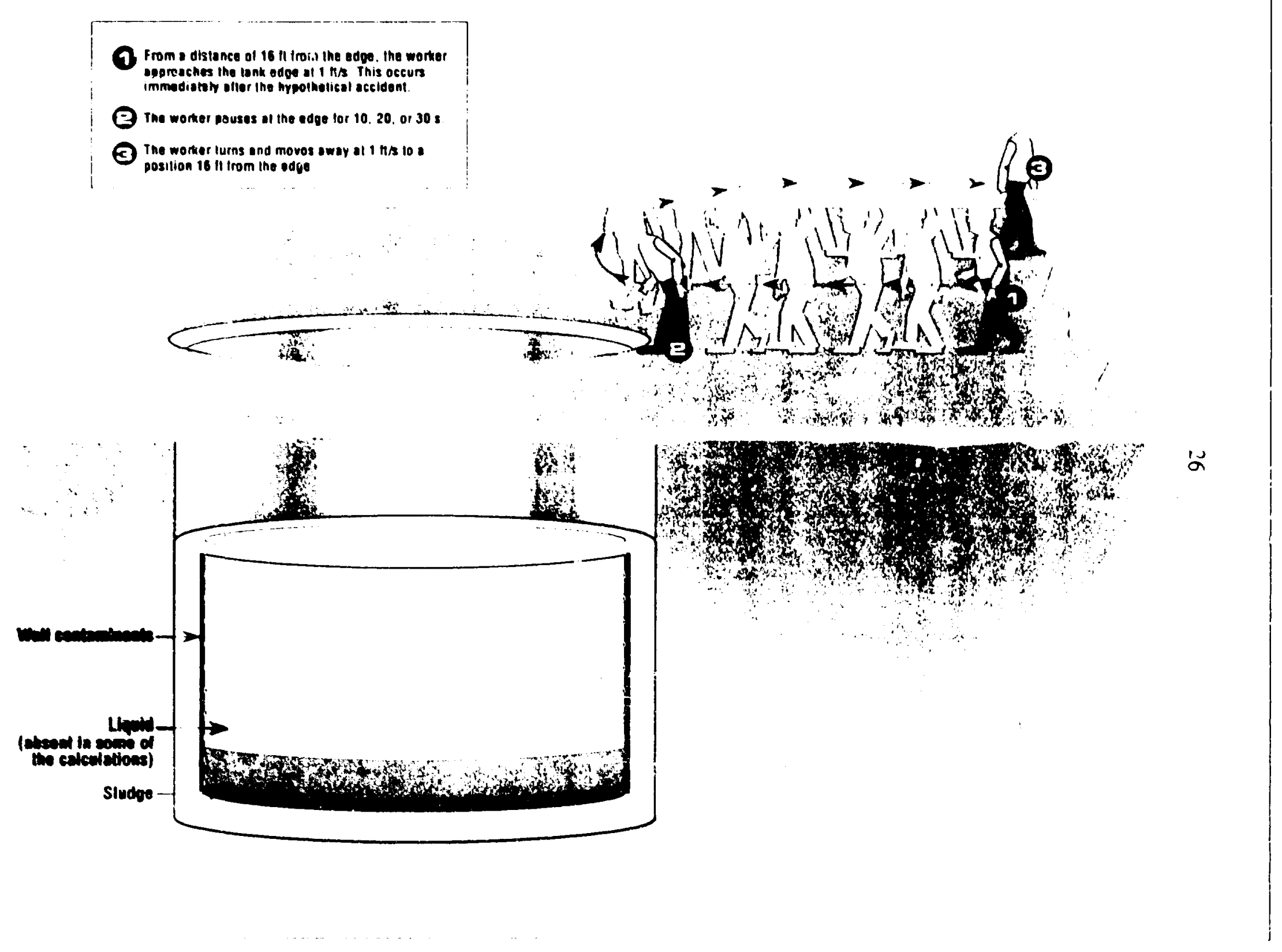

Fïg. 10. Investigator expxosure scenarios, calculation set 4. 


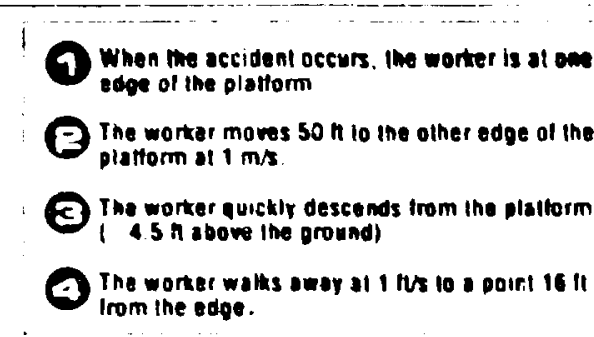

\section{am}

The worter maves so $n$ lo the other edge of the
plattorm al $1 \mathrm{~ms}$ The worter quickly descends from ine plattorm
is 1 abowe ine ground) The worker waths oway 31 I Us 10 a poirt 161 $\mathbf{Q}$
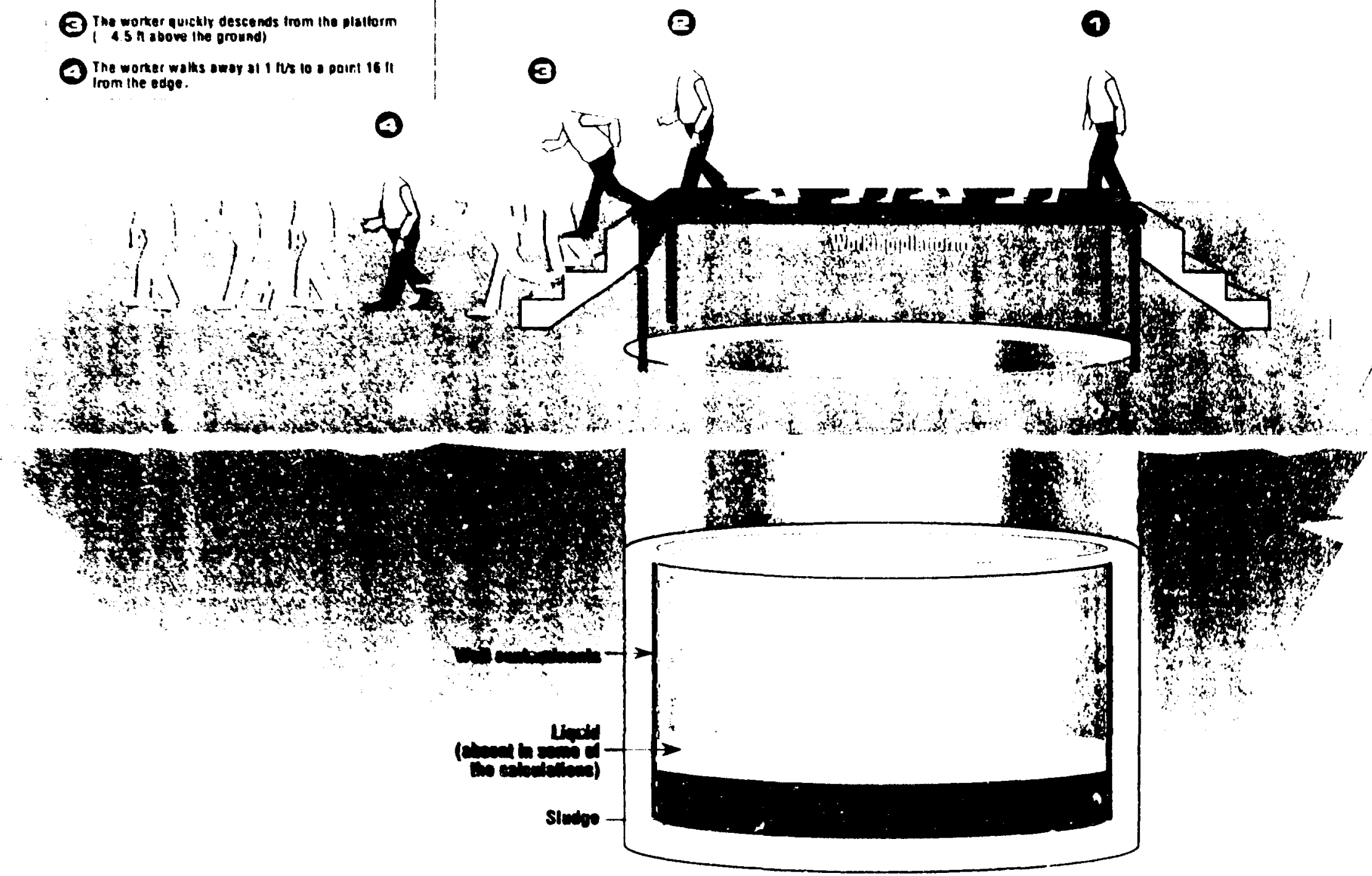

Fig. 11 . Fupitive esposure scenario, calculation set 4. 
might exist near the tank. Radiation worker training would inciude disciplined responses to upset conditions, such as evacuation, with planned and controlleo reantry to the area within prescribed limits. With regard to the fugitive scenario, it is acknowledged that a trained radiation worker on the platform when the postulated accident occurred would probably flee by the shortest and most direct route available. Assuming that a worker would cross from one edge of the tank to the other may be unrealistic, but again, the purpose of this calculation set is to provide exposure estimates based on ultraconservative evacuation routes and conditions.

The selection of a 16-ft-long evacuation or investigation distance on the ground is somewhat arbitrary, but a study of Tables $2 a$ and $2 b$, which give exposure rates out $w$ a distance of $25 \mathrm{ft}$ from the tank's inner rim, indicates that use of the 16-ft distance account; iv' over 97\% of the cumulative exposure possible compared to using the full 25 -ft distance.

The total exposures were calculaied by

- determining the exposure rates at regular intervals siong the path oi taposure (this was done in calculation set 1 at $1-f t$ intervals out from the tank edge, and in calculation set 2 at 1 -m intervals along the tank radius);

- multiplying the exposure rates by the time required to traverse the distance from one detector location to another (assumed to be 1 second in the investigator and fugitive scenarios); and

- summing the individual detector exposures over the exposure path of interest.

\subsection{RESULTS AND ANALYSES}

Table 4 gives the total exposures for the investigator and fugitive scenarios outlined above. Note that althGugh the exposure rates in calculation sets 1 and 2 were determined for two separate elevations ( $4 \mathrm{ft}$ and $6 \mathrm{ft}$ ), separate total exposures for different elevations are not given in Table 4 . This is because the total exposures were determined using the average of the elevation-specific exposure rates.

Table 4. Total exposures (aboye background) for worker response scenarios (mR)

\begin{tabular}{|c|c|c|c|c|}
\hline \multirow[b]{3}{*}{ Source Term } & \multicolumn{4}{|c|}{ Worker Response Scenarios } \\
\hline & \multicolumn{3}{|c|}{ Investigator } & \multirow[b]{2}{*}{ Fugitive } \\
\hline & $\begin{array}{l}\text { Case } 1 \\
(10 \text { s) }\end{array}$ & $\begin{array}{l}\text { Case } 2 \\
(20 \mathrm{~s})\end{array}$ & $\begin{array}{c}\text { Case } 3 \\
(30 s)\end{array}$ & \\
\hline Sludge (no liquid layer) and tank walls & 151 & 231 & 311 & 170 \\
\hline Sludge, liquid, and tank walls & 6.8 & 10.4 & 13.9 & 8.8 \\
\hline
\end{tabular}

- A person working $16 \mathrm{ft}$ from the tank investigates the accident-generated noise by (a) approaching the tank edge at $1 \mathrm{fv} / \mathrm{s}$, (b) viewing the damage for either 10,20 or 30 seconds while standing at the tank edge, and then (c) returning to the starting position at $1 \mathrm{ft} / \mathrm{s}$.

- A person (a) traverses the length of the working platform at $3.3 \mathrm{ft} / \mathrm{s}(1 \mathrm{~m} / \mathrm{s})$, (b) descends to the ground. and then (c) moves to a location $16 \mathrm{ft}$ from the tank edge at the rate of $\mathrm{I} \mathrm{ft} / \mathrm{s}$. 
The exposires for the investigator and fugitive scenarios were the same order of magnitude for a particular combined source. For the sludge-plus-walls source, total exposures for the investigator scenario ranged from 151 to $311 \mathrm{mR}$, depending on the time spent at the tank edge viewing the damage, and the total exposure for the fugitive scenario was $170 \mathrm{mR}$. These calculated exposures (in excess of background) are roughly equivalent to the average exposure to natural background, which is approximately $270 \mathrm{mrem} /$ year. For the sludge-plus-liquid-plus-walls source, total exposures were an order of iriagnitude less than for the sludge-plus-walls source because of the attenuating effect on the sludge by the liquid layer; total exposures ranged from 6.8 to $13.9 \mathrm{mR}$ for the investigator scenario, and the total exposure was $8.8 \mathrm{mR}$ for the fugitive scenario.

In both worker response scenarios considered, the estimated total exposure values for the hypothetical worker are below the annual regulatory limits recommended by DOE and ORNL. The DOE radiation dose limit for an individual during routine conditions is $5000 \mathrm{mrem} /$ year and the DOE administrative control level during routine conditions is $2000 \mathrm{mrem} /$ year. The ORNL absolute goal during routine conditions is 1000 mrem/year; however, its ALARA (as low as reasonably achievable) administrative goal is $750 \mathrm{mrem} /$ year. This ORNL A LARA goal is more than a factor of 2 greater than the maximum (and conservative) exposure of $2 ! 1 \mathrm{mR}$ shown in Table 4. [Note: the dose unit of mrem mentioned in the regulatory limits is rot ghly equivalent (within $5 \%$ of) to the exposure unit of $m R$ for cesium-137 gamma rays in an external exposure pathway.]

\section{CONCLUSIONS}

The purpose of this report was to model the unplanned external gamma exposure rates and total exposures potentially occurring after a hypothetical collapse of the tank W-10 dome. Even though the conservative model assumed no shielding contribution from the overburden, and even though the exposure scenarios assumed worker responses contrary to what might be expected based on worker training and site precautions, computed exposure rates were found to decrease relatively quickly with distance from the tank edge (i.e., at background within 25 to $50 \mathrm{ft}$ of the tank edge), and the total exposures were found to be less than the regulatory and administrative annual limits for workers. 


\section{REFERENCES AND BIBLIOGRAPHY}

Autrey. J. W. et al. 1990. Sampling and Analysis of Inactive Weste Storage Tant Contents at ORNL, ORNL/ER-13, Oak Ridge National Laboratory, Oak Ridge, Tennessee.

Bechtel 1991. "Radionuclide Inventory in the WAG I Inactive Tanks," 01-TB-18, Rey. 0, Oak Ridge, Tennessee.

Bechtel 1992. Video Inspection Data Manual for Inactive LLLW Storage Tanks at Oak Ridge National Laborat'sry, Oat Ridge, Tennessee, ORNI/ER/Sub/87-99053/45, Rev. 1, Oak Ridge, Tennessee.

Cain, V. R. 1977. A Users Manual for QAD-CG. The Combinatorial Geometry Version of the QADPSA Point Kernel Shielding Code, Radiation Shielding Information Center (RSIC) Computer Code Collection, Oak Ridge National Laboratory, Oak Ridge, Tennessee. RSIC No. CCC-493.

EPA 1988. Limiting Values of Radionuclide Intake and Air Concentration and Dose Conversion Factors for Inhalation, Submersion, and Ingestion, Federal Guidance Report II, EPA/520/188/M20, Office of Radiation Programs, Washington, D.C.

EPA 1991. Health Effects Assessment Summary Tables, OERR 9022.6-303, Annual FY-1991.

Ferrada, J. J. et al. 1990. Management Strategy for Gunite Tanks Liquid Inventory, ORNL/ER/INT14, Oak Ridge National Laboratory, Oak Ridge, Tennessee.

Fricke, K. E. 1986. Seismic Analysis of the Underground Gunite Tanks at the ORNL South Tank Farm, X-03-313, Oak Ridge Gaseous Diffusion Plant, Oak Ridge, Tennessee.

Grove Engineering 1987. "Microshield," Grove Engineering, Rockville, Maryland.

Mynatt, F. R. and C. C. Webster 1963. An Analysis of the South Tank Farm and the Potential Hazards Associated with Continued Use of the Tanks as Part of the Intermediate-Level Liquid Waste Disposal System, ORNL/TM-604, Oak Ridge National Laboratory, Oak Ridge, Tennessee.

ORNL 1992a. Waste Characterization Data Manual for the Inactive Liquid Low-Level Waste Tank Systems at Oak Ridge National Laborarory, Oak Ridge, Tennessee, ORNL./EK-80, Oak Ridige National Laboratory, Oak Ridge, Tennessee.

ORNL 1992b. Site Characterization Summary Report for Waste Area Grouping I at Oak Ridge National Laboratory, Oat Ridge, Tennessee, Yolume 1, DOE/OR-1043/V1\&D1, Oak Ridge National Laboratory, Oak Ridge, Tennessee. 
APPENDIX A:

COMPUTER CODE DESCRIPTIONS 


\section{A.1 INTRODUCTION}

QAD-CG/GP is a 3-dimensional, combinational geometry, point kernel gamma radiation shielding code that is usually used to aid in technical evaluation of exposure or flux from shielded or unshielded radioactive sources.

- The model handles many diffe, ent volume source and shield geometries in a combinatorial fashion. The geometries are rectangular parallelepiped, box, sphere, right circular cylinder, right i:liptical cylinder, truncated right angle cone, ellipsoid, right angle wedge, and arbitrary convex polyhedron of 4,5 , or 6 sides.

- For the input file, the user defines the radionuclides for source loading in terms of their gamma energy and flux. The user also defines the decay correction of the radionuclides for the input file. The number of radionuclides that can be selected is limited because the code allows a limited number of gamma energy groups.

- Shield materials are custom-built oy the user from the built-in table of elements and their shielding properties. The shielding material can be formed from a combination of elements with a user's specified density; the user provides the partial density of the elements in the shielding material.

- Handles many shield material regions and combinations.

- The code will calculate build-up in one of the shield or source materials; allowed build-up materials are aluminum, concrete, iron, lead, and water.

- The program is executed in batch mode. Case files are created via use of an editor with 80character fixed record length (i.e., FORTRAN type).

MICROSHIELD is a gamma radiation shielding code that is usually used to aid in technical evaluation of exposure from shielded or unshielded radioactive sources and uses point kernel integration for volumetric geometries. The code has the following features

- Handles 14 different source-shield geometries. The shield geometries are slab, cylindrical, and spherical. The source geometries are point, line, sphere, truncated cone, disk, cylinder (from side and end), rectangular area, infinite plane, and infinite slab. The user can define the dimensions of the source and the distance from the detector to the source, but not the shield dimensions except for thickness.

- Has a built-in radionuclide library for source loadings. It also has a built-in decay correction element called RADDECAY that can be executed separately (outside of the main program), which allows the user to decay-correct the selected radionuclides selected for source loading. 
- Has 16 built-in shield materials and their shielding properties, but the user can choose to create custom shield material from the built-in element table. In both cases the user can determine both density and thickness for the shielding materials.

- Handles five material regions and an air gap. Regions are numbered one through five - one source material and four shield material regions. The air gap is automatically selected by the program from user-specified dimensions for a user-specified geometry.

- The code will calculate build-up in one of the shield or source materials; the user specifies source/shieıd number for build-up calculation.

- The program can be executed in both batch and interactive modes; case file creation is interactive and is very user-friendly. The program can also perform one parameter sensitivity analysis.

\section{a.1.1 QAd Calculational TecíniQues}

For gamma ray calculations, the QAD codes use the point-kernel ray-tracing technique. In this method, the point kernel representing the transfer of energy by the uncollided flux along a line-ofsight path is combined with an appropriate buildup factor to account for the cont ibution from the scattered photons. With a distributed source, the point kernel is integrated over the source volume for each source energy considered. Expressed as an equation, the gamma ray dose rate at any point due to an isotropic source emitting $S$ photons of energy $E$ per second per unit volume is

$$
D\left(\mathbf{F}^{\prime}\right)=K_{V} \int \frac{S\left(\vec{I}^{\prime}\right) B\left(\mu\left|\vec{r}-\vec{r}^{\prime}\right|, E\right) \exp \left(-\mu\left|\overrightarrow{\mathbf{r}}-\overrightarrow{\mathbf{r}}^{\prime}\right|\right)}{4 \pi\left|\vec{r}-\overrightarrow{\mathbf{r}}^{\prime}\right|^{2}} d V
$$

where

$$
\begin{aligned}
& \bar{r} \quad=\text { point at which gamma dose rate is to be calculated, } \\
& \left|\overrightarrow{r^{\prime}}\right|=\text { location of source in volume } V \\
& \mathrm{~V}=\text { volume of souice region } \\
& \mu \quad=\text { total attenuation coefficieni at energy } E \text {, } \\
& \vec{r} \cdot \vec{r} \quad=\begin{array}{l}
\text { distance between source point and poirt at which gamma intensity is to be } \\
\text { calculated, }
\end{array} \\
& \mathrm{B}(\mu \overline{\mathrm{r}}-\overline{\mathrm{r}}, \mathrm{E}=\text { dose buildup factor, }
\end{aligned}
$$




$$
\mathbf{K}=\text { conversion factor (flux-to-dose rate). }
$$

The buildup factors used in the QAD-P5A code are based on the Goldstein and Wilkins moments method calculations for gamma-ray transport in infinite homogeneous media. The code uses Capo's fit to the Goldstein-Wilkins data with bivariant polynomial expressions to calculate the appropriate buildup factors as a function of the gamma ray energy and the number of mean free paths from the source to the detector. For high-atomic-number materials, the polynomial fit has the form

$$
B\left(\mu\left|\vec{r}-\vec{r}^{i}\right|, E\right) \sum_{j=0}^{j=4 i=3} \sum_{i=0} C_{i j}\left(\mu \mid \vec{r}-\vec{r}^{\prime}\right)^{i}(E)^{j}
$$

and for low-innic-nuniber miatsxials it has the form

$$
B\left(\mu \mid \vec{x}-\vec{Z}^{\prime} i, E\right)=\sum_{j=0}^{j=4} \sum_{i=0}^{i=3} c_{i j}\left(\mu\left|\vec{r}-\vec{r}^{\prime}\right|\right)^{j}\left[\frac{1}{E}\right]^{j}
$$

where the $C_{i j}$ 's are the coefficients of the exparsicn.

lising these infirite-medis $m$ bididup factors should result in an c vere:timate of the dose rate : a surface exter:al tc the source region since it implies that reflecting tnaterial is located beyond th. surface. However, becauss of the strorig preferential forward siante: ing of photons, the error will usually not be more thar: a few percent and only in rather criusual cases will it reach 20 or $30 \%$.

Using single material buildup faciors fnr multilayered shieids or for shields made up mixtures of materials zar, se another source of arror. For multilayered siructures having an outer layer that is thicker than 2 oi 3 mean free paths, the buildup actor used should be the one representing the outer layer, bus the total nurricer of mean tree paths should be the number along the line of sight through ail materials in the structure. This is a reasoniole procedure sirce the gamrna ray spectrum would readjust to the new medium and tend $w$ anproach the spectrum that would exist if the whole structure consisted of the outer layer, particularly when a low-atomic-number material is followed by a high-atomic-number material. For homogeneous mixtures or compounds, the so-called equivalent $Z$ (atomic number) method can be used.

For multilayered structures in which each layer is less than 2 mean free paths thick, no clear-cut procedure is available. It has been shown that if one assumes that the structure is made entirely of the material having the largest buildup factor, then the dose is overestimated. Conversely, if one assumes that the material having the lowest buildup factor is representative of the structure, then the dose is underestimated. 
The QAD code calculates the dose at a detector for each source energy group $j$ with the following equation, which is a finite difference form of $\mathrm{Eq}$. (1):

$$
D_{j}=\sum_{i} K_{j} \frac{S_{i j}}{4 \pi R_{i}^{2}} \exp \left[-\sum_{k}\left[\mu_{j} t\right)_{k}\right] B_{j k}
$$

where

$$
\begin{aligned}
& \mathbf{j}=\text { energy group index, } \\
& \mathbf{i}=\text { source point index, } \\
& \mathbf{k}=\text { region index, } \\
& \mathbf{K}=\text { flux-to-dose conversion factor (raf/unit flux), } \\
& \mathbf{S}=\text { voiume-weighted gamma ray point source strength (photons/s), } \\
& \mathbf{R}=\text { distance from source point to detector }(\mathrm{cm}), \\
& \mathbf{B}=\text { dose buildup factor, } \\
& \boldsymbol{\mu}=\text { total attenuation coefficient }\left(\mathrm{cm}{ }^{-1}\right), \\
& \mathbf{t}=\text { zone penetration distance }(\mathrm{cm}) .
\end{aligned}
$$

The total dose is obtained by summing the contribution from each of the source energies.

\section{A.1.2 MICROSHIELD CALCULATIONAL TECHNIQUES}

MICROSHIELD uses point kernel integration to calculate exposure rates at the receiver point from volumetric sources. The following sections describe the calculation method.

Point Kernel Integration Parameters-Point-kernel numeric integration is performed for cylindrical and rectangular solid sources. The geometric integration parameters represent the number of divisions in each direction which determine the numbei of kernels into which the source is divided. Each kernel is calculated as a point source solution and the overall result is the sum of the results for all the kernels. Simpsons's Rule formulation is used, the difference relative to the discussion above is that the user specifies the sigmentation for integration. 
It is important to understand the meaning of integration parameters. For the point kernel method, 25 viewed from the dose point, integration is performed incrementally along a horizontal angle, a vertical angle, and by steps that increase radially. Of the three integration parameters, called $\mathbf{N}_{\text {twa }}, \mathbf{N}_{\mathrm{m}}$, and $\mathbf{N}_{\mathrm{m}}$, the first two represent the number of intervals into which the angular ranges are divided. For example, if the range of theta is $100^{\circ}, \mathrm{N}_{\infty}=11$ means that each sector is $10^{\circ}$, that is, $100 \div(11-1)$.

$\mathbf{N}_{\text {nim }}$ represents the number of intervals into which a line projected from the dose point through the source is divided where the length is from the nearest to the furthest point within the source. The radial increment is only a starting point based on the perpendicular distance through the source. During the course of calculation, the actual number of radial intervals will depend on the distance through the source for the line being integrated for each kernel. Also note that if in the course of the radial march away from the dose point, a kernel's contribution to dose rate is less than one-tenthousandth of the nearest kernel, then convergence for that radial line is assumed. This may reduce the calculation time for thick sources that are very dense.

The values chosen for the integration parameters determine how finely the source volume is divided for the numerical integration.

Buildup Factor-The effects of photon scattering contributions at the dose point are calculated by use of buildup factors which are based on empirical models derived from measurements. For thick. dense shields, the buildup will be a larger fraction of the total dose than for weak shielding of the same source; however, the total results will be less.

The no buildup option is provided because it is sometimes useful to know to what degree the buildup factor calculation affects the results. This can be observed by comparing cases with and without buildup. If such a comparison shows buildup to be a significant contribution to the total, and if the results are of significance relative to a design or operational decision, then it is important to investigate the range of results with different buildup methods and material bases.

Buildup Factor Formulations-The various expressions for buildup factor that follow are all based on the number of shielding mean free paths, $\mu \mathrm{r}$, at a source energy, $E$. The number of coefficients for Taylor, GP, and Berger methods are 3,5, and 2, respectively. These coefficients are a function of the material atomic number and incident photon energy. In MICROSHIELD, the coefficients for the Taylor and Berger methods are compiled with the source code, whereas the coefficients for the GP method are read from the disk file. The three methods are expressed by:

Taylor

$$
B F(E, \mu t)=A(E) * e^{-*} 1^{(B) \cdot \mu t}+[1-A(E)] * e^{-*} 2^{(E) \cdot \mu t}
$$

where the tabulated coefficients are $A, \alpha_{1}$, and $\alpha_{2}$. 
GP

$$
\mathrm{BP}\left(E_{, \mu \mathrm{r}}\right)=1+(\mathbf{b}-1) \frac{\left(\mathbf{K}^{\boldsymbol{N}}-1\right)}{(\mathbf{K}-1)} \text { for } K * 1
$$

$$
B F(E, \mu r)=1+(b-1) * \mu r \text { for } K=1
$$

and

$$
K(\mu r)=c *(\mu r)^{2}+d \frac{\tanh \left(\frac{(\mu r)}{X_{k}}-2\right)-\tanh (-2)}{1-\tanh (-2)}
$$

\section{Berger}

$$
B F(E, \mu r) 1+a(E) * \mu r * e^{*(B) * \mu r}
$$

where the tabulated coefficients are $a$ and $b$.

Material Basis for Buildup Calculation-If a method other than "No Buildup" is chosen, then the material upon which the buildup is based must be specified. In the case of the Taylor and GP methods, the material is chosen by selecting one of the shields. In the case of the Berger method, the material is chosen from one of air, water, concrete, iron, or lead.

After all material and source entries have been processed, the user is requested to verify the shield or material to be used to calculate buildup. Examples for each are shown on the screen. The generil rule is to use either the last material between the source and dose pnint or the most dominant shield. The latter will produce the greatest buildup factor.

As an example, if a shield arrangement of steel, water, and steel is used for a tank of water hatween the dose point and source, unless otherwise specified, the buildup factor associated with iron, the last shield region, will generally be the greatest. If the water-filled dimension of the tank 
is large compared to the other dimensions, the analyst may consider it to be more appropriate to evaluate the buildup factor using water rather than iron.

In MICROSHIELD, the Berger buildup coefficients are based on the pure material designated. Thus, even though shields may be represented by mixed material, the buildup is based on only the selected one.

Method of Calculating Buildup-During the process of kernel integration, the buildup factor for each differential source volume is calculated for all of the materials between the source point and dose point. Values of the line-of-sight distance between the source kernel through the shields between it and the dose point are calculated for each new source point by trigonometric relationships. The attenuation mean free paths are determined and used in the buildup factor calculation.

The so-called infinite medium buildup factor method is used. The shielding mean free paths for all material between the source and dose point are used, with the buildup characteristics of one of the materials selected by the user. This approach is believed to be the most general and gives a good approximation for most shield configurations.

In the most general case, the material and incident photon energy will not necessarily be one of those for the tabulated sets of coefficients provided with the program. Therefore, interpolation for both parameters may be required.

Interpolation for energy is done for the coefficients before the buildup factor formula is calculated. Linear interpolation is used for the Taylor and Berger correlations and logarithmic interpolation is used for the GP method.

Interpolation for materials is done after the buildup factor formula is calculated. The radiation buildup factor for the mixture of materials is determined by first calculating the effective atomic number (EAN) of the material in the shield region. The effective atomic number is used as an index to interpolate in a built-in table of coefficients for calculating buildup factors. The buildup factor is calculated using coefficients tabulated at material atomic numbers that bracket the effective atomic number of the reference case material. Linear interpolation of the two bracketing buildup factors is then done with the EAN as the interpolating parameter. That is:

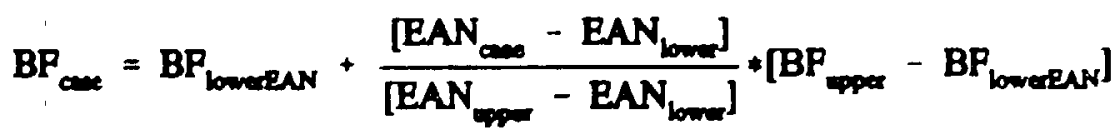

where the coefficients for determination of buildup factor are energy specific. 
APPENDIX B:

MICROSHIELD INPUT FILES 


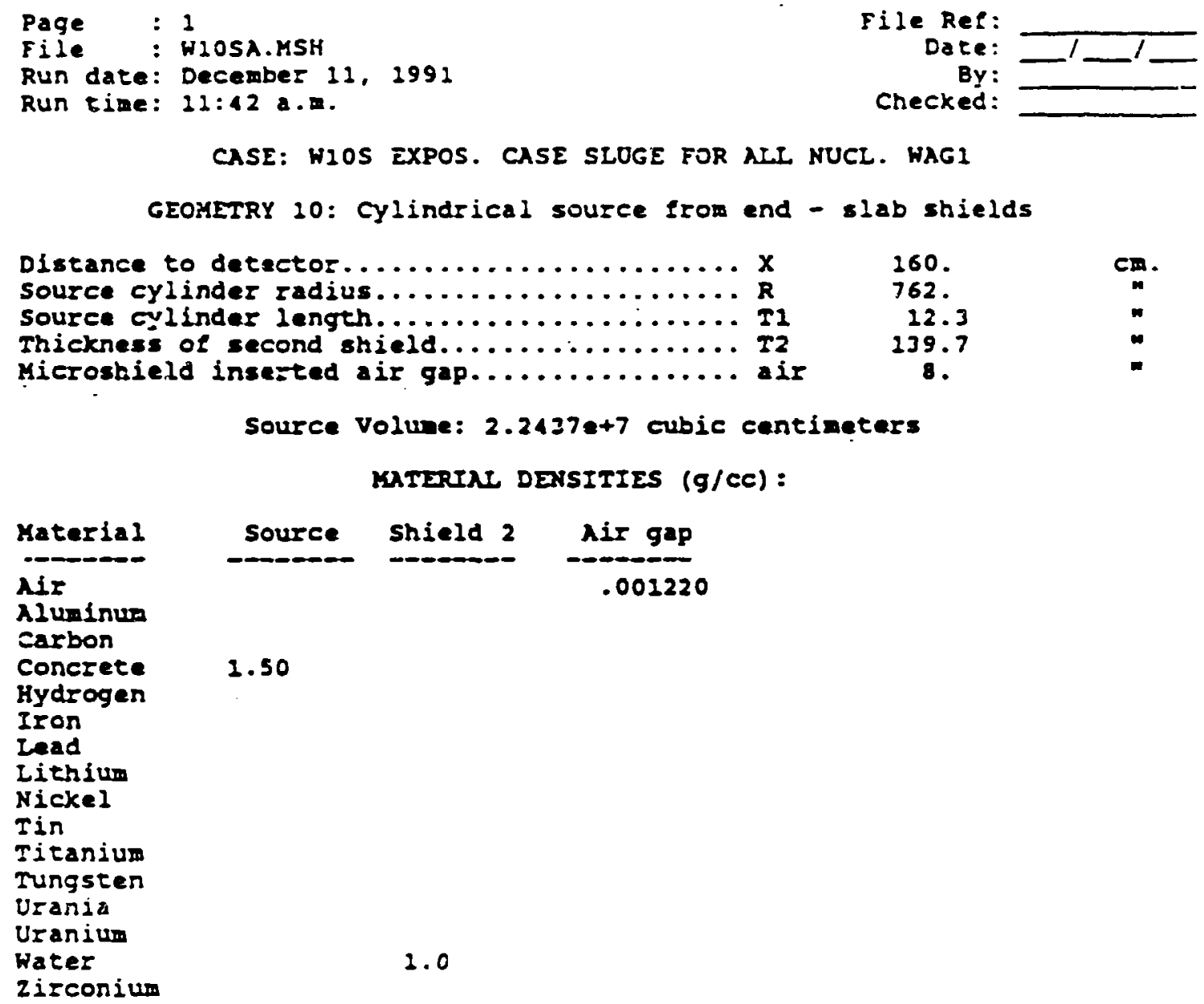

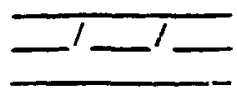

CASE: WIOS EXPOS. CASE SLOGE FOR ALL NUCL. WAGI GEOMETRY 20: Cylindrical souzce frow end - slab shields

Source volume: $2.24374+7$ cubic centinetars

MATERAI DENSITIES (g/cc):

Page 2

CASE: WIOS EXPOS. CASE SLUGE FOR ALL NUCL. WAGL

BUILDUP FACTOR: based on GP metnod. Using the characteristics of the materials in shield 2 .

\section{INTEGRATION PARAMETERS:}

Number of angle segments (Npsi)...........

Nuelide Curies

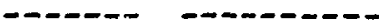
cm-244 4.6000e+02 Cs-137 1.1000e+04 H-3 $1.4000 e-01$ SE $-90 \quad$ B. $5000 e+03$ $y-9 n \quad 8.5000 e+03$ 


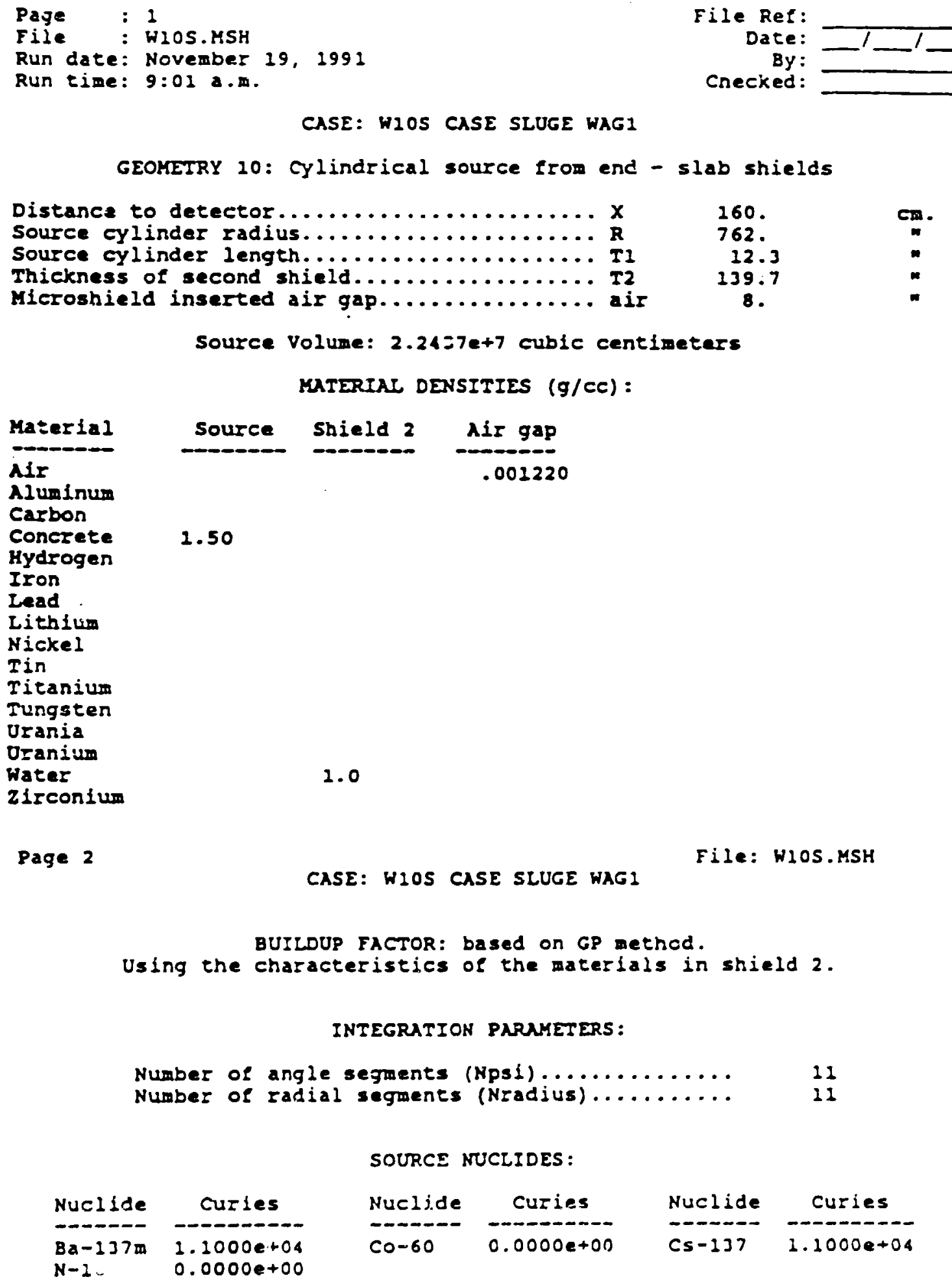

CASE: HIOS CASE SLUGE WAGI

GEOMEIRY 10: Cylindrical source from end - slab shields

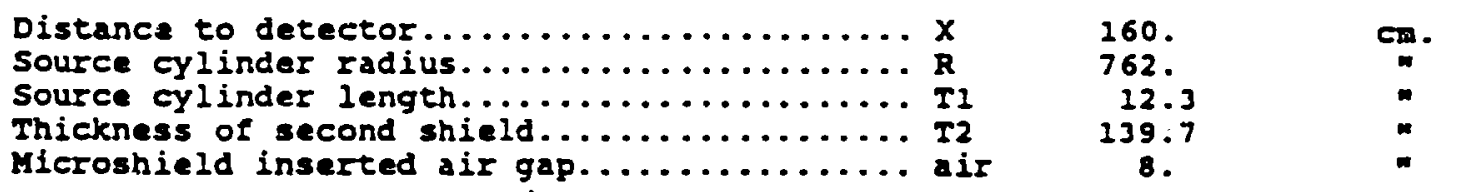

Mlcroshield inserted air gap............. air

Source volume: $2.24=7 e+7$ cublc centimeters

MLIERIAL DENSITIES (g/cc):

\begin{tabular}{llll} 
Material Source Shield 2 & Air gap \\
\hline Air & Siuminum & & .001220
\end{tabular}

Aluminum

Carbon

Concrete $\quad 1.50$

Hydrogen

Iron

Iead

Lithium

Nickel

Tin

ritanium

Tungsten

Urania

Uranium

Water

1.0

zirconium

Page 2

CASE: HIOS CASE SLUGE WAGI

File: WLOS.MSH

BUILDUP FACTOR: based on GP method.

Using the characteristics of the materials in shield 2 .

INTEGRATION PARNMETERS:

Number of angle segments (Npsi)............ 11

Number of radial segments (Nradius).......... 11

SOURCE NUCLIDES:

\begin{tabular}{llllll} 
Nuclide & Curles & Nuclide & Curies & Nuclide & Curies \\
\hline Ba-137m & $1.1000 e+04$ & Co-60 & $0.0000 e+00$ & Cs-137 & $1.1000 e+04$ \\
$N-1$ & $0.0000 e+00$ & & & &
\end{tabular}




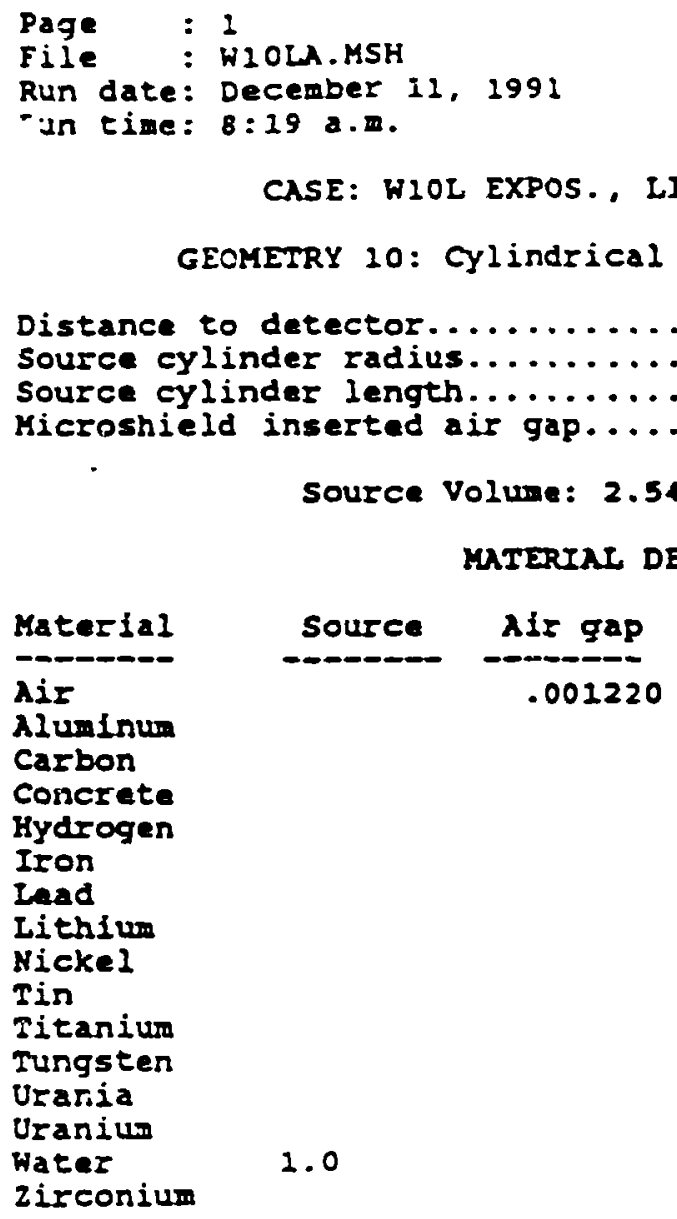

CASE: WIOL EXPOS., LIQUID PART, ALL NUCL., WAGI

GEOMEIRY 10: Cylindrical source from end - siab shields

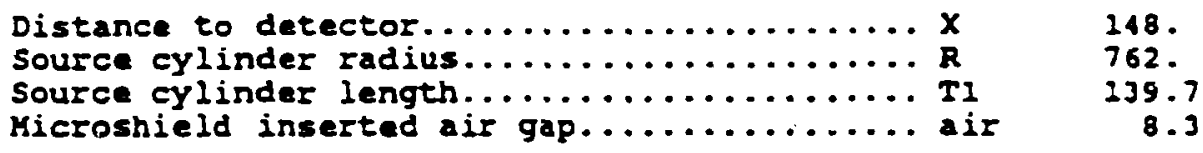

Page 2

\section{INTEGRATION PARAMETERS:}

Number of angle segments (Npsi) ........... Number of radial segments (Nradius)...........

\begin{tabular}{|c|c|c|c|c|c|}
\hline Nuclide & Curies & Nuel1de. & Curies & Nuclıde & curies \\
\hline$-\infty-\infty$ & --- & ----- & $--\infty-2-\infty$ & $---\infty-\infty$ & -- \\
\hline $\begin{array}{l}A m-241 \\
C 0-60 \\
E U-152 \\
P U-238 \\
U-233\end{array}$ & $\begin{array}{l}0.0000 \mathrm{e}+00 \\
1.0000 \mathrm{e}+00 \\
0.0000 \mathrm{e}+00 \\
0.0000 \mathrm{e}+00 \\
5.1000 \mathrm{e}-02\end{array}$ & $\begin{array}{l}B a-137 m \\
C s-134 \\
E u-154 \\
P u-239 \\
U-234\end{array}$ & $\begin{array}{l}1.7000 e+03 \\
0.0000 e+00 \\
0.0000 e+00 \\
1.4000 e-02 \\
2.2000 e-02\end{array}$ & $\begin{array}{l}\mathrm{Cm}-244 \\
\mathrm{Cs}-237 \\
\mathrm{H}-3 \\
\mathrm{~S}=90 \\
\mathrm{Y}=90\end{array}$ & $\begin{array}{l}0.0000 e+00 \\
1.7000 e+03 \\
0.0000 e+00 \\
8.7000 e+00 \\
8.7000 e+00\end{array}$ \\
\hline
\end{tabular}



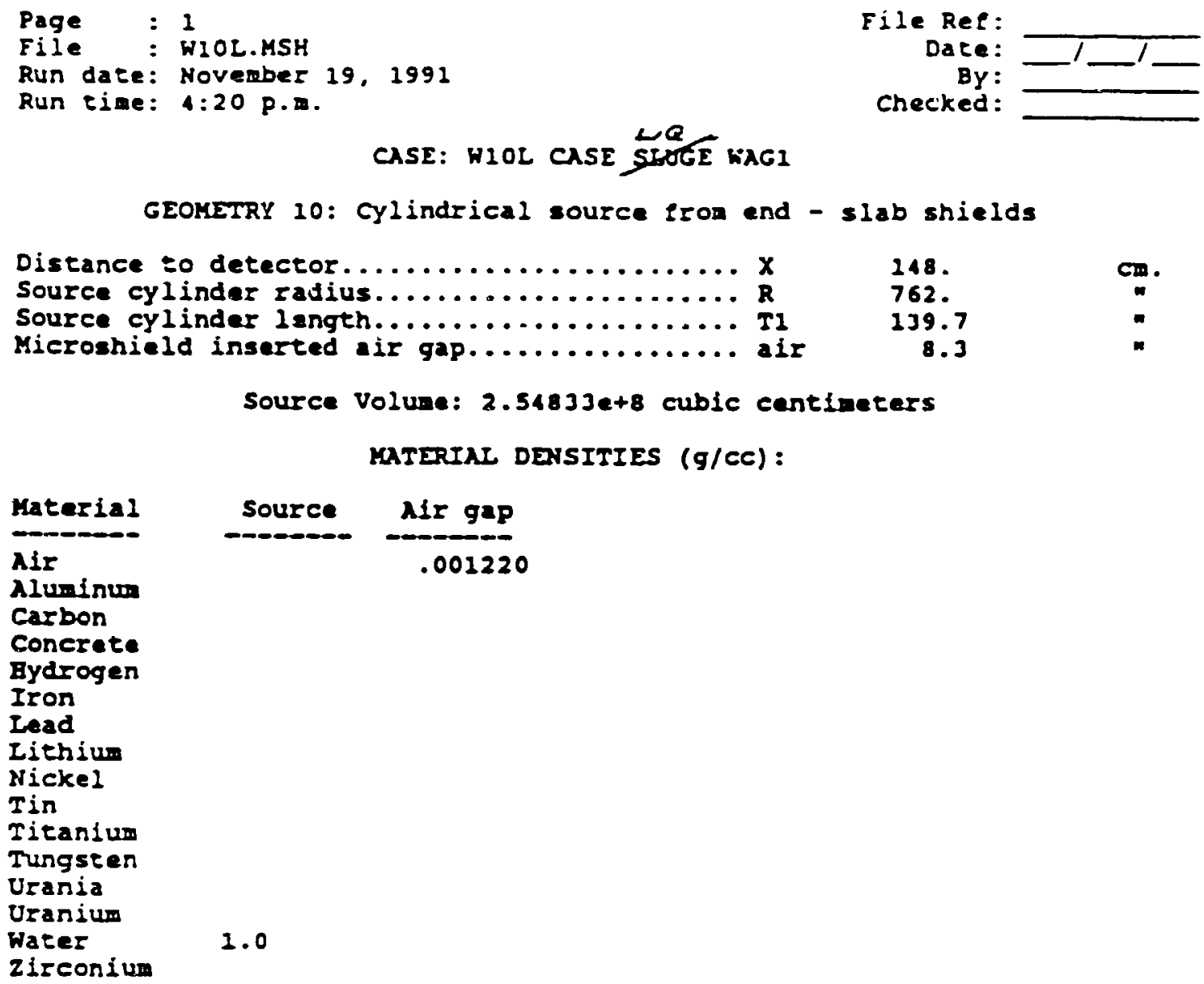

Page 2

CASE: WLOL CASE SLUGE WAGI

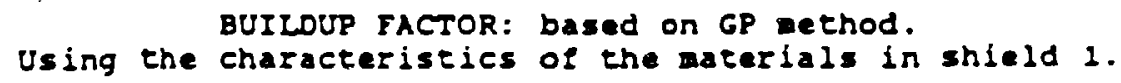

\begin{tabular}{llllll} 
Nuclide & Curies & Nuclide & Curles & Nuclide & Curies \\
\hdashline $\mathrm{Ba}-137 \mathrm{y}$ & $1.7000 e+03$ & Co-60 & $0.0000 e+00$ & $\mathrm{Cs}-137$ & $1.7000 \mathrm{0}+03$
\end{tabular}




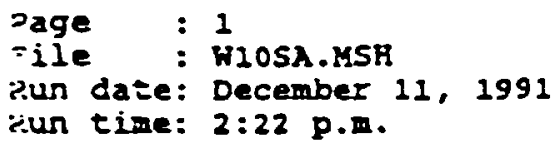

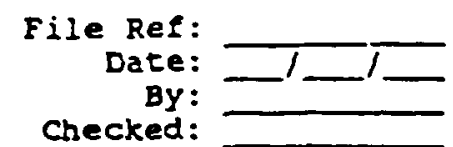

Checked:

CASE: HIOS EXPOS. CASE SLUGE FOR ALL NOCL. WAGI NO LIQUID GEOHEIRY 10: Cyllndrical source from end - slab shields

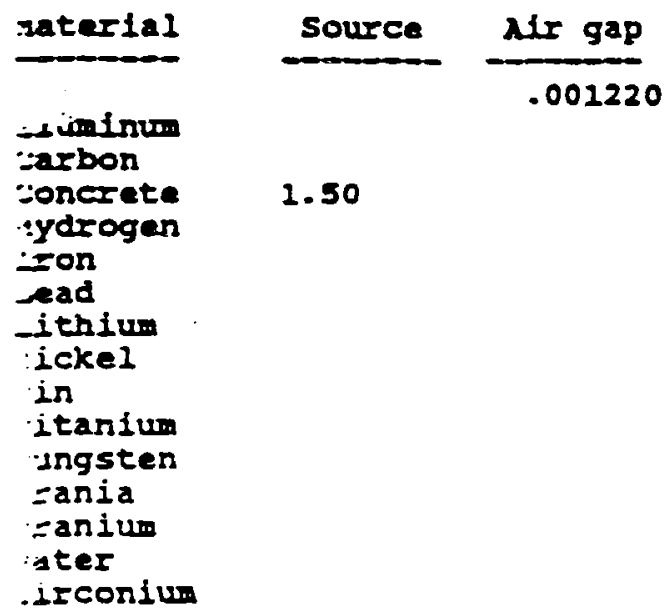$$
1.50
$$
MATERTII DENSITIES (g/Cc):

Source Volume: $2.2+37 e+7$ cubic centimeters

Page 2

CASE: WIOS EXPOS. CASE SLUGE FOR AIL NUCL. WAGI NO IIQUID

BUILUUP FACTOR: based on GP method. Using the characteristics of the materials in shield 2.

\section{INTEGRATION PARAMETERS:}

Number of angle segments (Nps1) ............ 11

Number of radial segments (Nradius) ........... 11

SOURCE NOCLIDES:

\begin{tabular}{|c|c|c|c|c|c|}
\hline Nuclide & curles & Nuclide & curies & Nuclide & Curles \\
\hline $\begin{array}{l}\lambda=-241 \\
C 0-60 \\
E u-152 \\
P u-238 \\
U-233\end{array}$ & $\begin{array}{l}4.4000 e+00 \\
1.3000 e+01 \\
4.5000 e+00 \\
2.9000 e+01 \\
2.1000 e+00\end{array}$ & $\begin{array}{l}\mathrm{Ba}-137 \mathrm{~m} \\
\mathrm{Cs}-134 \\
\mathrm{Eu}-154 \\
\mathrm{Pu}-239 \\
\mathrm{U}-234\end{array}$ & $\begin{array}{l}1.1000 \text { e }+04 \\
1.4000 e+00 \\
7.9000 e+00 \\
1.1000 e+01 \\
1.3000 \text { e }+00\end{array}$ & $\begin{array}{l}C m-244 \\
C s-137 \\
H-3 \\
S E-90 \\
Y-90\end{array}$ & $\begin{array}{l}4.6000 \mathrm{e}+01 \\
1.1000 \mathrm{e}+04 \\
1.4000 \mathrm{e}-01 \\
8.5000 \mathrm{e}+0 \mathrm{~J} \\
8.5000 \mathrm{e}+03\end{array}$ \\
\hline
\end{tabular}




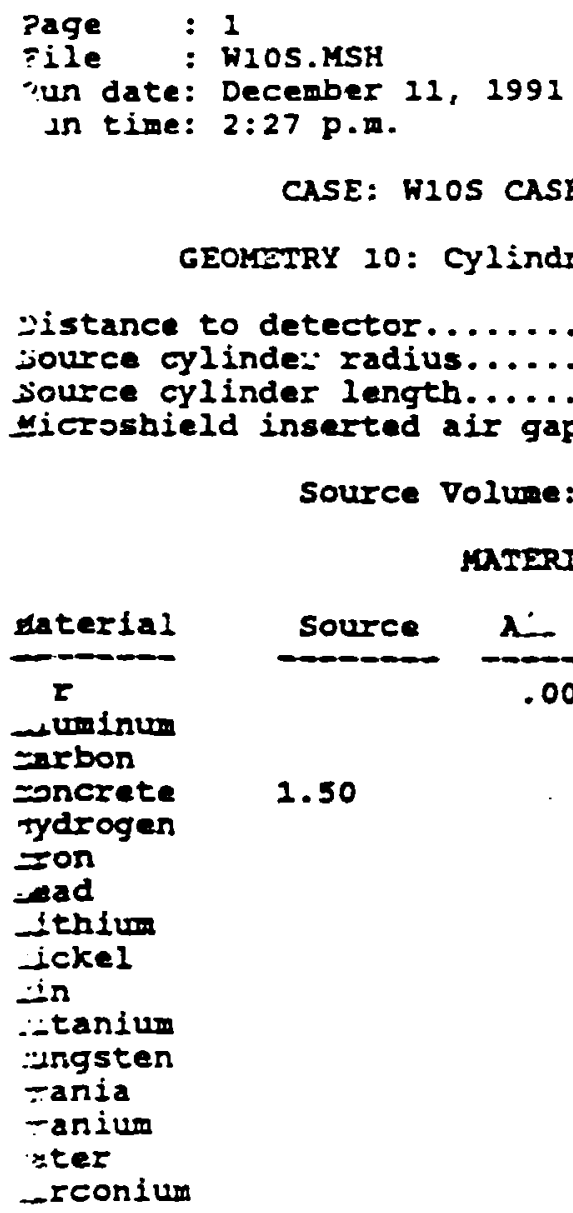

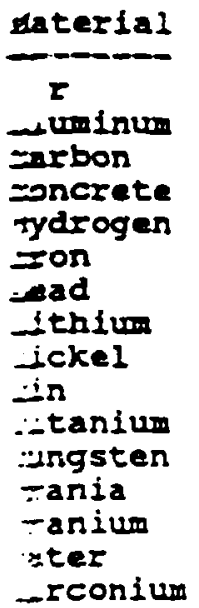

CASE: HLOS CASE SLUGE WAGI CS-137 ONLY NO IIQ

GEOMETRY 10: Cylindrijal source from end - slab shields

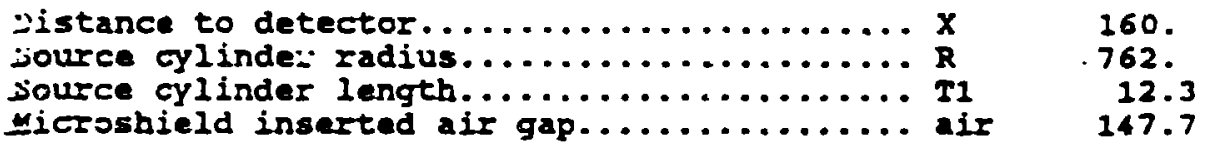

Source Volume: $2.2437 e+7$ cubic centimeters MATERTRI DENSITIES (g/Cc):

-rge 2

CASE: WIOS CASE SLUGE WRGI CS-137 ORLY NO LIQ

BUIIOUP FAFTOR: based on GP method.

Using the characteristics of the materials in shield 2.

INTEGRATION PARANETERS:

Number of angle segments (Nps1)............ 11

Number of radial segments (Nradius).......... 11

SOURCE NUCLIDES:

\begin{tabular}{llllll} 
Nuclide & Curles & Nucl1de & Curies & Nuclida & Curies \\
\hdashline $\mathrm{Ba}-137 \mathrm{~m}$ & $1.1000 \mathrm{e}+04$ & $\mathrm{C}-60$ & $0.0000 \mathrm{e}+00$ & $\mathrm{cs}-137$ & $1.1000 \mathrm{e}+04$ \\
$\mathrm{~N}-16$ & $0.0000 \mathrm{e}+00$ & & & &
\end{tabular}


APPENDIX C:

QAD-CGGP INPUT FILES 
INPUT DATA LIST

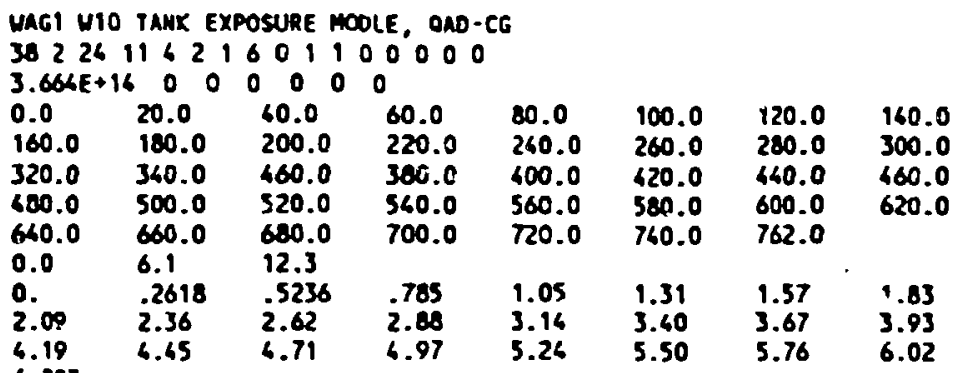

6.283

0 OAD-CG MAGI WIO TIUK EXFOS. MODLE SLLO. FM=NIOSZ.IWP

$\begin{array}{lllll}0.0 & 0.0 & 0.0 & 0.0 & 12.3\end{array}$

ace 20.0

$\begin{array}{lllll}0.0 & 0.0 & 0.0 & 0.0 & \$ 52.0\end{array}$

$0.0 \quad 0.0$

$0.0 \quad 0.0$

0.0

599.46

762.0

$0.0 \quad 0.0$

0.0

0.0

599.46

trep 701.05

1000.0

$-1000.0 \quad 1000.0 \quad 0.0$

1000.0

1002,1

10023

$\begin{array}{llll}110 & 2 & 2 & -1 \\ 120 & 2 & 3 & -1\end{array}$

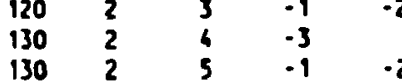

Eno

1

$\begin{array}{llll}1 & 1 & 1 & 1 \\ 2 & 3 & 4 & 1000\end{array}$

$\begin{array}{lllllllllll}2 & 7 & 8 & 11 & 12 & 17 & 16 & 16 & 19 & 20 & 26\end{array}$

$\begin{array}{lllllllll}.008 & .000 & 0.678 & .023 & .006 & .068 & .670 & .060\end{array}$

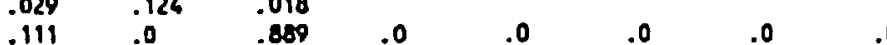

$.111 \quad .0$

.0

.0

.0103

.045

.00104

.0

.0
.194

.88

.00025 .

1.006

0.6641

0.6641

.0019231

1.0

$.660 \cdot .670$

$.660-.670$

mev/ent 2-sec

\section{0}

-sec $762 . m^{m e a / h r}$

629.44762 .0

659.44762 .0

$609.64 \quad 762.0$

$719.66 \quad 762.0$

$740.64 \quad 762.0$

$779.64 \quad 762.0$

$\begin{array}{ll}0.0 & 0.0\end{array}$

$\begin{array}{llll}1 & 0 & 0 & 0 \\ 1 & 0 & 0 & 0 \\ 1 & 0 & 0 & 0 \\ 1 & 0 & 0 & 0 \\ 1 & 0 & 0 & 0 \\ 1 & 0 & 0 & 0 \\ 1 & 0 & 0 & 0 \\ 1 & 0 & 0 & 0\end{array}$

$w / 8$ 
IMPUT DATA LIST

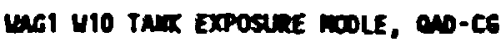

38162611321601100000

$5.46 E+13$ O 00000

$\begin{array}{llllllll}0.0 & 20.0 & 69.0 & 60.0 & 80.0 & 100.0 & 120.0 & 140.0\end{array}$

$\begin{array}{llllllll}160.0 & 180.0 & 200.0 & 220.0 & 260.0 & 260.0 & 260.0 & 300.0\end{array}$

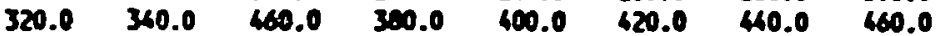

$\begin{array}{llllllll}400.0 & 500.0 & 520.0 & 560.0 & 560.0 & 500.0 & 600.0 & 620.0\end{array}$

$\begin{array}{lllllll}640.0 & 660.0 & 600.0 & 700.0 & 720.0 & 760.0 & 762.0\end{array}$

$\begin{array}{lllllll}80.0 & 90.0 & 100.0 & 110.0 & 120.0 & 130.0 & 139.7\end{array}$

$\begin{array}{llllllll}\text { J. } & .2618 & .5236 & .785 & 1.05 & 1.31 & 1.57 & 1.83\end{array}$

$\begin{array}{llllllll}2.09 & 2.36 & 2.62 & 2.88 & 3.16 & 3.40 & 3.67 & 3.93\end{array}$

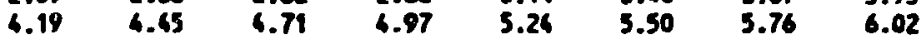

6.203

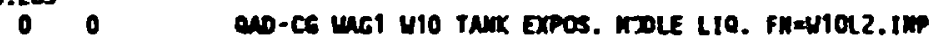

$\begin{array}{lllllll}\text { RCC } & 10.0 & 0.0 & 0.0 & 0.0 & 0.0 & 139.7\end{array}$

20.0

$0.0 \quad 0.0 \quad n .0$

$0 . c$

587.46

Rec 30.0

$0.0 \quad 0.0$

0.0

0.0

587.46

781.05

1000.0

$-1000.0 \quad 1000.0$

0.0

1000.0

ETO

$\begin{array}{llll}100 & 2 & 1 & \\ 110 & 2 & 2 & -1\end{array}$

$\begin{array}{ll}120 & 2 \\ 130 & 2\end{array}$

$\begin{array}{lll}-1 & & \\ -2 & -1 & \\ -1 & -2 & -3\end{array}$

$\begin{array}{rlll}E & 1 & 1\end{array}$

1231000

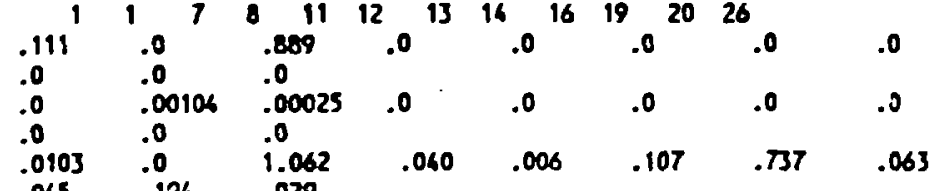

.045

.124

.029

0.6641

.0019231

1.0

$.660-.670$

$.660 \cdot .670$

aev/com 2-8ee

$\begin{array}{lll}0.0 & 587.14 & 762.0\end{array}$

0.0

617.14

762.0

$677.16 \quad 762.0$

$707.16 \quad 762.0$

$737.16 \quad 762.0$

$767.16 \quad 762.0$

0.0

0.0

0.0

rew/hr

$\begin{array}{llll}1 & 0 & 0 & 0 \\ 1 & 0 & 0 & 0 \\ 1 & 0 & 0 & 0 \\ 1 & 0 & 0 & 0 \\ 1 & 0 & 0 & 0 \\ 1 & 0 & 0 & 0 \\ 1 & 0 & 0 & 0 \\ 1 & 0 & 0 & 0\end{array}$

$w / g$ 
IMPUT DATA LIST

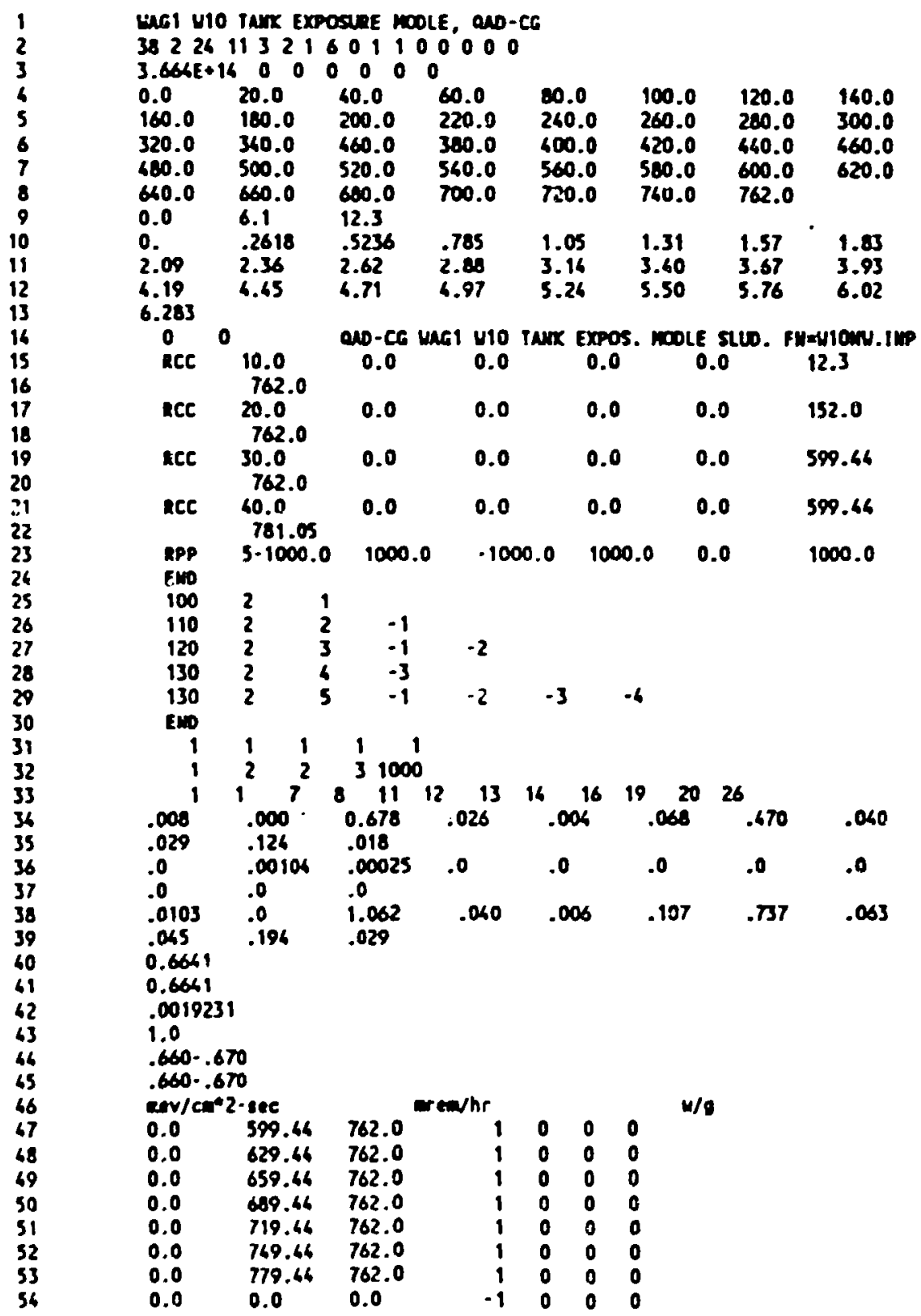


IMPUT DATA LIST

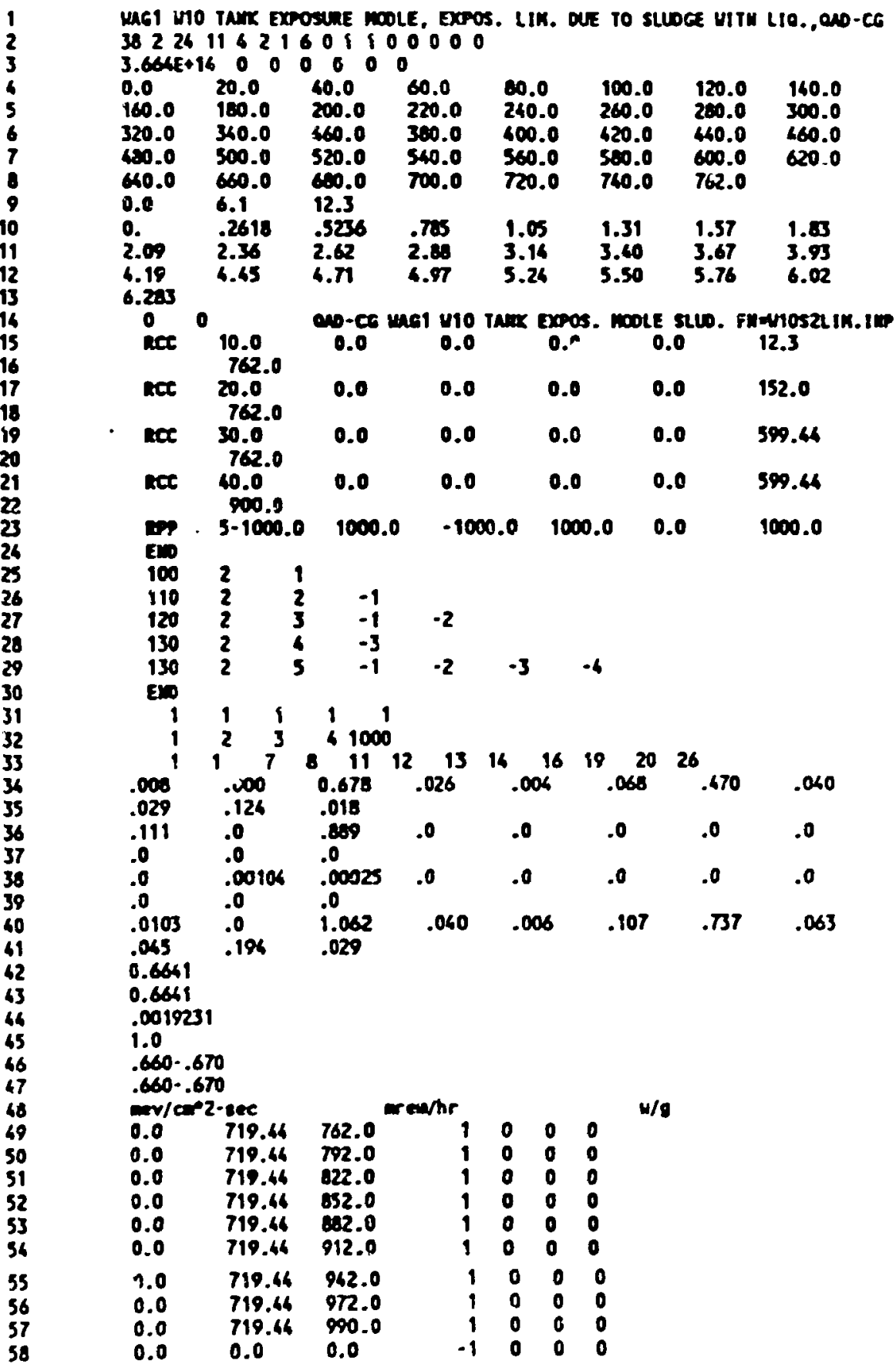


InPer oata LI:T

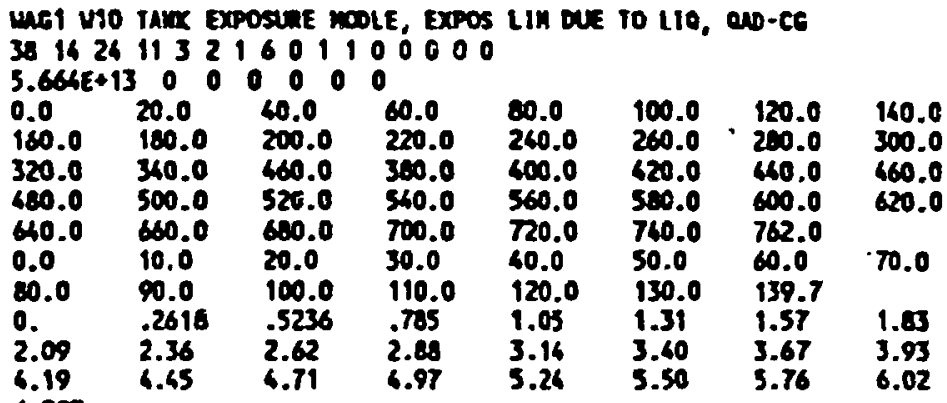

6.203

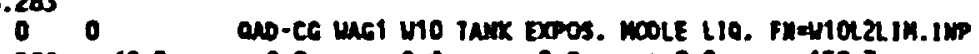

$\begin{array}{lllllll}\text { Rec } 10.0 & 0.0 & 0.0 & 0.0 & 10.0 & 139.7\end{array}$

762.0
20.0

762.0

nee 30.0

$0.0 \quad 0.0$

0.0

0.0

587.64

IPP $4-9000.0$

$0.0 \quad 0.0$

0.0

0.0

587.46

Emo

$1000.0 \quad-1000.0 \quad 1000.0$

0.0

1000.0

100
110

110
120

130

$\begin{array}{lll}2 & 1 & -1 \\ 2 & 2 & -1\end{array}$

$\begin{array}{lllll}2 & 2 & -1 & & \\ 2 & 3 & -2 & -1 & \\ 2 & 4 & -1 & -2 & -3\end{array}$

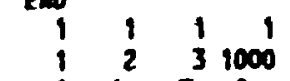

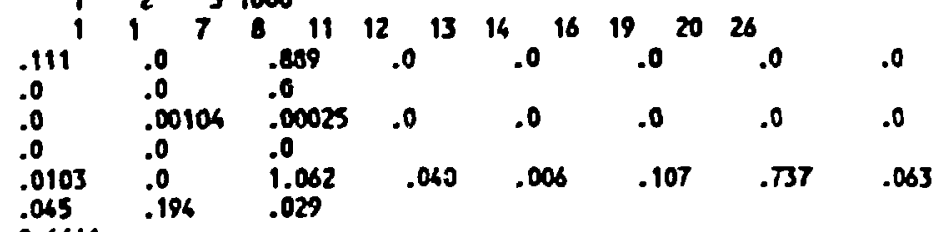

0.6641

0.6641

.0019231

1.0

$.660-.670$

$.660-.670$

mor/cares-sec

$\begin{array}{ll}0.0 & 707.14 \\ 0.0 & 707.16\end{array}$

$0.0 \quad 707.16$

$0.0 \quad 707.16$

$0.0 \quad 707.16$

$0.0 \quad 707.16$

$0.0 \quad 707.16$

$0.0 \quad 707.16$

$0.0 \quad 707.16$

$0.0 \quad 707.16$

707.1
0.0

762.0 mewhe

762.0

792.0

822.0

852.0

822.0

912.0

962.0

972.0

990.0

0.0

$\begin{array}{rlll}1 & 0 & 0 & 0 \\ 1 & 0 & 0 & 0 \\ 1 & 0 & 0 & 0 \\ 1 & 0 & 0 & 0 \\ 1 & 0 & 0 & 0 \\ 1 & 0 & 0 & 0 \\ 1 & 0 & 0 & 0 \\ 1 & 0 & 0 & 0 \\ 1 & 0 & 0 & 0 \\ -1 & 0 & 0 & 0\end{array}$

$w / s$ 
IMPUI DATA LIST

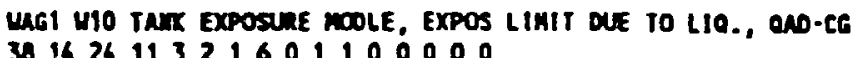

$$
\begin{aligned}
& 30142611321601100000 \\
& \text { 5.664E+i3 } 00000000 \\
& \begin{array}{llllllll}
0.0 & 20.0 & 40.0 & 60.0 & 80.0 & 100.0 & 120.0 & 160.0
\end{array} \\
& \begin{array}{llllllll}
160.0 & 180.0 & 200.0 & 220.0 & 240.0 & 260.0 & 280.0 & 300.0
\end{array} \\
& \begin{array}{llllllll}
320.0 & 360.0 & 460.0 & 360.0 & 400.0 & 420.0 & 640.0 & 660.0
\end{array} \\
& \begin{array}{llllllll}
480.0 & 500.0 & 520.0 & 540.0 & 560.0 & 580.0 & 600.0 & 620.0
\end{array} \\
& \begin{array}{lllllllll}
640.0 & 660.0 & 680.0 & 700.0 & 720.0 & 760.0 & 762.0 & \\
0.0 & 10.0 & 20.0 & 30.0 & 40.0 & 50.0 & 60.0 & 70.0
\end{array} \\
& \begin{array}{lllllll}
80.0 & 90.0 & 100.0 & 110.0 & 120.0 & 130.0 & 139.7
\end{array} \\
& \begin{array}{llllllll}
0 . & .2618 & .5236 & .785 & 1.05 & 1.31 & 1.57 & 1.83
\end{array} \\
& \begin{array}{llllllll}
2.09 & 2.36 & 2.62 & 2.80 & 3.16 & 3.40 & 3.67 & 3.93
\end{array} \\
& \begin{array}{llllllll}
4.19 & 4.65 & 4.71 & 4.97 & 5.26 & 5.50 & 5.76 & 6.02
\end{array} \\
& 6.283 \\
& \text { ace } 10.0
\end{aligned}
$$

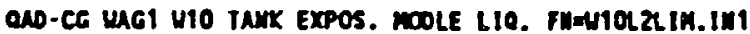

$$
\begin{aligned}
& \begin{array}{lllll}
0.0 & 0.0 & 0.0 & 0.0 & 139.7
\end{array} \\
& 762.0 \\
& \text { rec } \quad \mathbf{2 0 . 0} \\
& 762.0 \\
& 0.0 \quad 0.0 \\
& 0.0 \\
& 0.0 \\
& 587.46 \\
& 0.0 \quad 0.0 \\
& 0.0 \\
& 0.0 \quad 587.64 \\
& 1500.0 \\
& 2000.6 \quad-2000.0 \quad 2000.0 \\
& 0.0 \quad 2000.0 \\
& \text { npp } \\
& \text { 4-2000.0 } \\
& 2000 \\
& 2000.0 \quad 0.0 \\
& \begin{array}{llll}
100 & 2 & 1 & \\
110 & 2 & 2 & -1
\end{array} \\
& \begin{array}{llllll}
120 & 2 & 3 & -2 & -1 & \\
130 & 2 & 4 & -1 & -2 & -3
\end{array} \\
& \text { ENO } 1111 \\
& 1231000 \\
& \begin{array}{lllllllllllll}
.111 & 1 & 1 & 7 & . & 11 & 12 & 13 & 14 & 16 & 19 & 20 & 26 \\
.0 & & .089 & .0 & & .0 & & .0 & & .0 & .0
\end{array}
\end{aligned}
$$

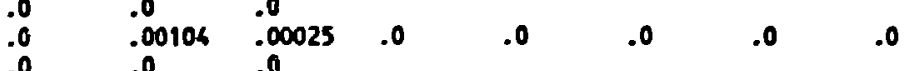

$$
\begin{aligned}
& \begin{array}{llllllll}
.0 & .0 & .0 & & & & \\
.0103 & .0 & 1.062 & .040 & .006 & .107 & .737 & .063
\end{array} \\
& .045 \\
& .194 \\
& .029 \\
& 0.6641 \\
& .0019231 \\
& 1.0 \\
& .660-.670 \\
& .660-.670 \\
& \text { enev/cones-sec } \\
& 0 . \\
& 707.16 \\
& \begin{array}{llllll}
707.16 & 1022.0 & 1 & 0 & 0 & 0 \\
707.16 & 1052.0 & 1 & 0 & 0 & 0
\end{array} \\
& 707.14 \quad 1082.0 \quad 1 \quad 0 \quad 0 \\
& \begin{array}{llllll}
707.16 & 1112.0 & 1 & 0 & 0 & 0
\end{array} \\
& \begin{array}{llllll}
707.16 & 1162.0 & 1 & 0 & 0 & 0
\end{array} \\
& \begin{array}{llllll}
707.16 & 1172.0 & 1 & 0 & 0 & 0
\end{array} \\
& \begin{array}{llllll}
707.16 & 1202.0 & 1 & 0 & 0 & 0
\end{array} \\
& \begin{array}{llllll}
707.16 & 1232.0 & 1 & 0 & 0 & 0 \\
0.0 & 0.0 & -1 & 0 & 0 & 0
\end{array}
\end{aligned}
$$


IMPUT DATA LIST

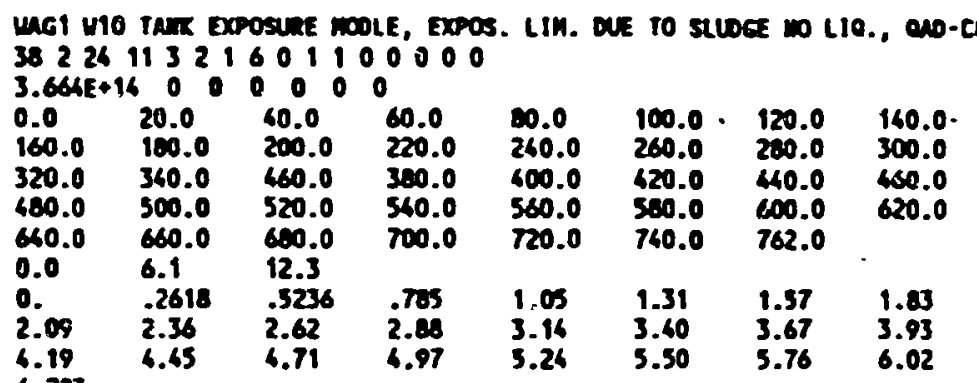

6.213

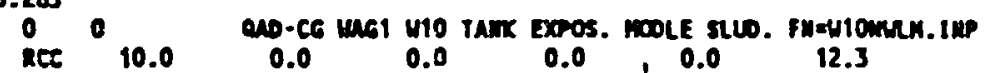

762.0

$\mathbf{2 0 . 0}$
$\mathbf{7 6 2 . 0}$

ace 30.0

762.0

ace $\quad 60.0$

990.0

0.00 .0

$0.0 \quad 0.0$

0.0

152.0

$0.0 \quad 0.0$

0.0

0.0

599.46

0.0

0.0

0.0

0.0

599.46

atp $5 \cdot 1000.0$

$1000.0 \quad-1000.0 \quad 1000.0$

0.0

1000.0

10025

11022.

$\begin{array}{lllll}120 & 2 & 3 & -1 & -2\end{array}$

$\begin{array}{lll}130 & 2 & 4 \\ 130 & 2 & 5\end{array}$

$\begin{array}{rllll}E & 1 & 1 & 1 & 1\end{array}$

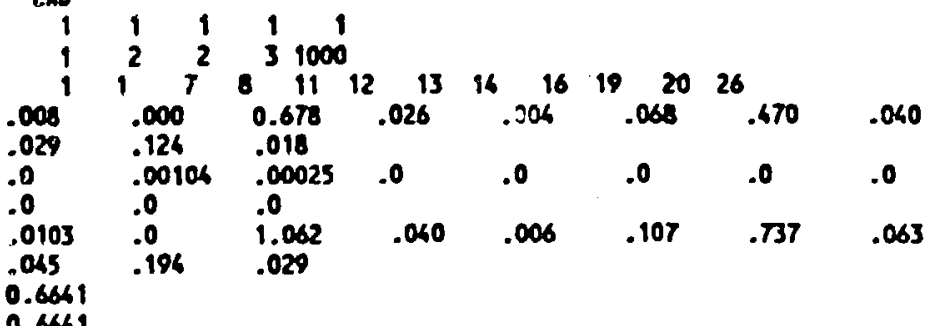

.0019231

1.0

$.660-.670$

$.660+.670$

Ev/car 2-sec

0.0

719.64

719.46

719.66

719.64

$719.46 \quad 822.0$

$719.44 \quad 912.0$

$719.46 \quad 962.0$

$719.46 \quad 972.0$

0.0

719.46

990.0

mran/hr

762.0

792.0

222.0

$-1000.0$

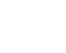

(1) 
InTUY DATA LIST

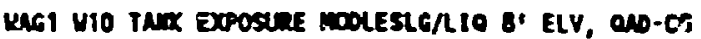

$$
\begin{aligned}
& 3822611421601100000 \\
& 3.664 E+16 \quad 0 \quad 000000 \\
& \begin{array}{llllllll}
0.0 & 20.0 & 40.0 & 60.0 & 60.0 & 100.0 & 120.0 & 160.0
\end{array}
\end{aligned}
$$

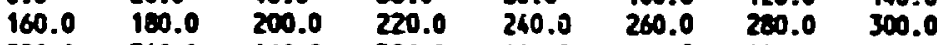

$$
\begin{aligned}
& \begin{array}{llllllll}
320.0 & 340.0 & 460.0 & 380.0 & 400.0 & 420.0 & 460.0 & 460.0
\end{array} \\
& \begin{array}{llllllll}
460.0 & 500.0 & 520.0 & 540.0 & 560.0 & 500.0 & 600.0 & 620.0
\end{array} \\
& \begin{array}{lllllll}
660.0 & 660.0 & 600.0 & 700.0 & 720.0 & 760.0 & 762.0
\end{array} \\
& \begin{array}{lll}
0.0 & 6.1 & 12.3
\end{array} \\
& \begin{array}{llllllll}
0 . & .2618 & .5236 & .705 & 1.05 & 1.31 & 1.57 & 1.83
\end{array} \\
& \begin{array}{llllllll}
2.00 & 2.36 & 2.62 & 2.60 & 3.16 & 3.40 & 3.67 & 3.93
\end{array} \\
& \begin{array}{llllllll}
4.14 & 4.45 & 4.71 & 4.97 & 5.24 & 5.50 & 5.76 & 6.02
\end{array} \\
& 6.283
\end{aligned}
$$$$
00
$$$$
\text { ace } 10.0
$$

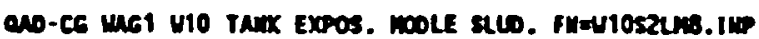

762.0

$0.0 \quad 0.0 \quad 0.0 \quad 0.0 \quad 12.3$

Ree 20.0

$0.0 \quad 0.0$

0.0

0.0

152.0

ece 30.0

0.00 .0

0.0

0.0

399.46

ace $\quad 60.0$

$0.0 \quad 0.0$

0.0

0.0

599.64

LPP $5-1000.0$

$1000.0 \quad-1000.0 \quad 1000.0$

0.0

1000.0

$\lim _{100} 2$

$\begin{array}{lll}100 & 2 & 1 \\ 110 & 2 & 2\end{array}$

$\begin{array}{llll}120 & 2 & 3 & -1\end{array}$

$\begin{array}{lll}130 & 2 & 4 \\ 130 & 2 & 5\end{array}$

-3
-1

En

$\begin{array}{rrrrr}1 & 1 & 1 & 1 & 1 \\ 1 & 2 & 3 & 4 & 1000\end{array}$

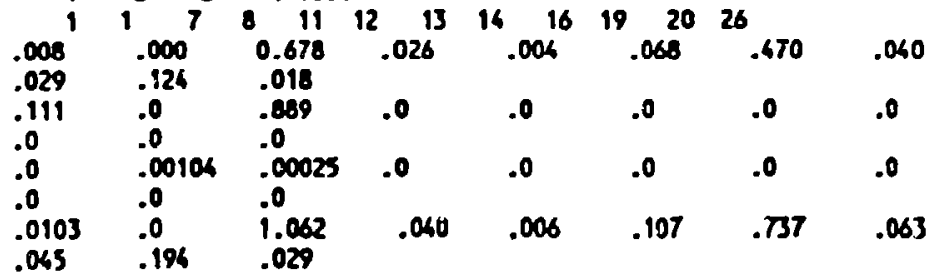

0.6661

0.6641

.0019231

1.0

$.660-.670$

$.660-.670$

mov/can'2-3me

$\begin{array}{lll}0.0 & 779.46 & 762.0\end{array}$

$0.0 \quad 79.64 \quad 792.0$

$0.0 \quad 779.46 \quad 822.0$

$0.0 \quad 779.64 \quad 852.0$

$0.0 \quad 79.44 \quad 882.0$

$0.0 \quad 779.44 \quad 912.0$

$0.0 \quad 79.46 \quad 962.0$

$0.0 \quad 79.44972 .0$

$0.0 \quad 79.46 \quad 990.0$

$\begin{array}{lll}0.0 & 0.0 & 0.0\end{array}$

weowhr

$\begin{array}{llll}1 & 0 & 0 & 0 \\ 1 & 0 & 0 & 0 \\ 1 & 0 & 0 & 0 \\ 1 & 0 & 0 & 0 \\ 1 & 0 & 0 & 0 \\ 1 & 0 & 0 & 0 \\ 1 & 0 & 0 & 0 \\ 1 & 0 & 0 & 0 \\ 1 & 0 & 0 & 0 \\ 1 & 0 & 0 & 0\end{array}$

w/o 
IMPUT DATA LIST

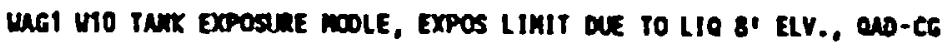
38162611321601100000

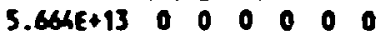

\begin{tabular}{|c|c|c|c|c|c|c|c|}
\hline $\begin{array}{l}0.0 \\
160.0 \\
320.0 \\
480.0 \\
640.0 \\
0.0 \\
80.0 \\
0 . \\
2.09\end{array}$ & $\begin{array}{l}20.0 \\
160.0 \\
340.0 \\
500.0 \\
660.0 \\
10.0 \\
90.0 \\
.2618 \\
2.36 \\
4.45\end{array}$ & $\begin{array}{l}40.0 \\
200.0 \\
660.0 \\
520.0 \\
60.0 \\
20.0 \\
100.0 \\
5236 \\
2.42 \\
4.71\end{array}$ & $\begin{array}{l}60.0 \\
220.0 \\
330.0 \\
540.0 \\
700.0 \\
30.0 \\
110.0 \\
.7 .5 \\
2.80 \\
4.97\end{array}$ & $\begin{array}{l}80.0 \\
260.0 \\
400.0 \\
560.0 \\
720.0 \\
40.0 \\
120.0 \\
1.05 \\
3.16 \\
5.26\end{array}$ & $\begin{array}{l}100.0 \\
260.0 \\
620.0 \\
560.0 \\
760.0 \\
50.0 \\
130.0 \\
1.31 \\
3.40 \\
5.50\end{array}$ & $\begin{array}{l}120.0 \\
200.0 \\
460.0 \\
600.0 \\
762.0 \\
60.0 \\
139.7 \\
1.57 \\
3.67 \\
5.76\end{array}$ & $\begin{array}{l}160.0 \\
300.0 \\
660.0 \\
620.0 \\
70.0 \\
1.03 \\
3.93 \\
6.02\end{array}$ \\
\hline
\end{tabular}

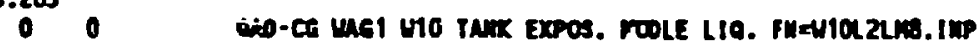

ace $\begin{array}{llllll}10.0 & 0.0 & 0.0 & 0.0 & 0.0 & 139.7\end{array}$

$\begin{array}{llllll}\text { Iec } 20.0 & 0.0 & 0.0 & 0.0 & 0.0 & 587.46\end{array}$

$\begin{array}{llllll}\text { RCC } 30.0 & 0.0 & 0.0 & 0.0 & 0.0 & 587.46\end{array}$

RPP $\quad \begin{array}{llllll}-2000.0 & 2000.0 & -2000.0 & 2000.0 & 0.0 & 2000.0\end{array}$

Ew

$\begin{array}{llll}100 & 2 & 1 \\ 110 & 2 & 2\end{array}$

$\begin{array}{llllll}110 & 2 & 2 & -1 & & \\ 120 & 2 & 3 & -2 & -1 & \\ 130 & 2 & 4 & -1 & -2 & -3\end{array}$

Ex) 1,1

$1 \quad 1 \quad 31000$

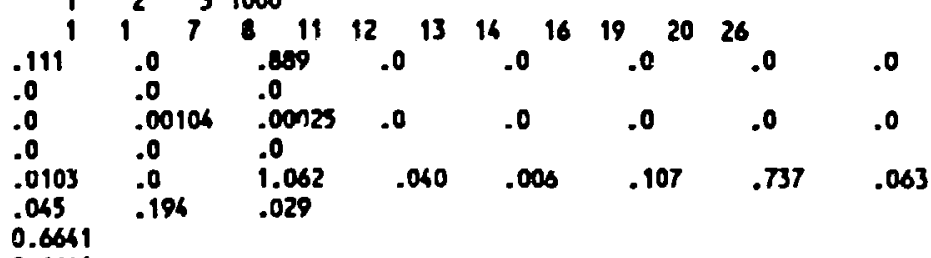

0.6841

.0019231

1.0

$.660-.670$

$.660-.670$

0.0 (cereces

$\begin{array}{lllllll}0.0 & 767.14 & 762.0 & 1 & 0 & 0 & 0\end{array}$

$\begin{array}{lllllll}0.0 & 767.16 & 822.0 & 1 & 0 & 0 & 0\end{array}$

$\begin{array}{lllllll}0.0 & 767.16 & 852.0 & 1 & 0 & 0 & 0\end{array}$

$\begin{array}{lllllll}0.0 & 767.16 & 882.0 & 1 & 0 & 0 & 0\end{array}$

$\begin{array}{lllllll}0.0 & 767.16 & 912.0 & 1 & 0 & 0 & 0\end{array}$

$\begin{array}{lllllll}0.0 & 767.16 & 962.0 & 1 & 0 & 0 & 0 \\ 0.0 & 767.16 & 972.0 & 1 & 0 & 0 & 0\end{array}$

$\begin{array}{llllll}0.0 & 767.16 & 990.0 & 1 & 0 & 0\end{array}$

$\begin{array}{lllllll}0.0 & 767.16 & 1022.0 & 1 & 0 & 0 & 0\end{array}$

$\begin{array}{lllllll}0.9 & 767.16 & 1052.0 & 1 & 0 & 0 & 0\end{array}$

$\begin{array}{lllllll}0.0 & 767.16 & 1082.0 & 1 & 0 & 0 & 0 \\ 0.0 & 767.16 & 1112.0 & 1 & 0 & 0 & 0\end{array}$

$\begin{array}{lllllll}0.0 & 767.14 & 1162.0 & 1 & 0 & 0 & 0\end{array}$

$\begin{array}{lllllll}0.0 & 767.16 & 1172.0 & 1 & 0 & 0 & 0\end{array}$

$\begin{array}{lllllll}0.0 & 767.16 & 1202.0 & 1 & 0 & 0 & 0\end{array}$

$\begin{array}{lllllll}0.0 & 767.16 & 1202.0 & 1 & 0 & 0 & 0 \\ 0.0 & 767.16 & 1232.0 & 1 & 0 & 0 & 0 \\ 0.0 & 0.0 & 0.0 & .1 & 0 & 0 & 0\end{array}$ 


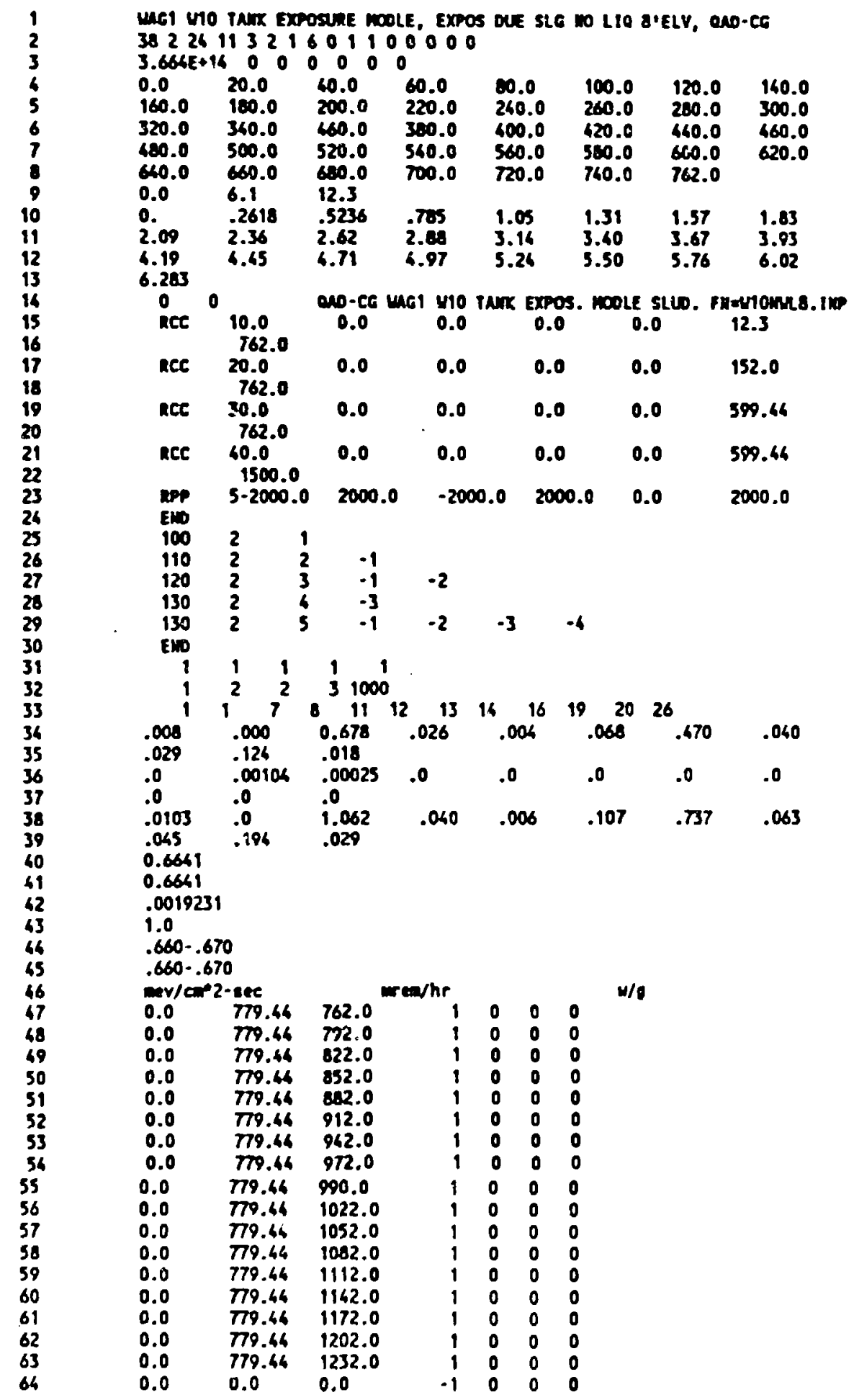


ImPUT OATA LIST

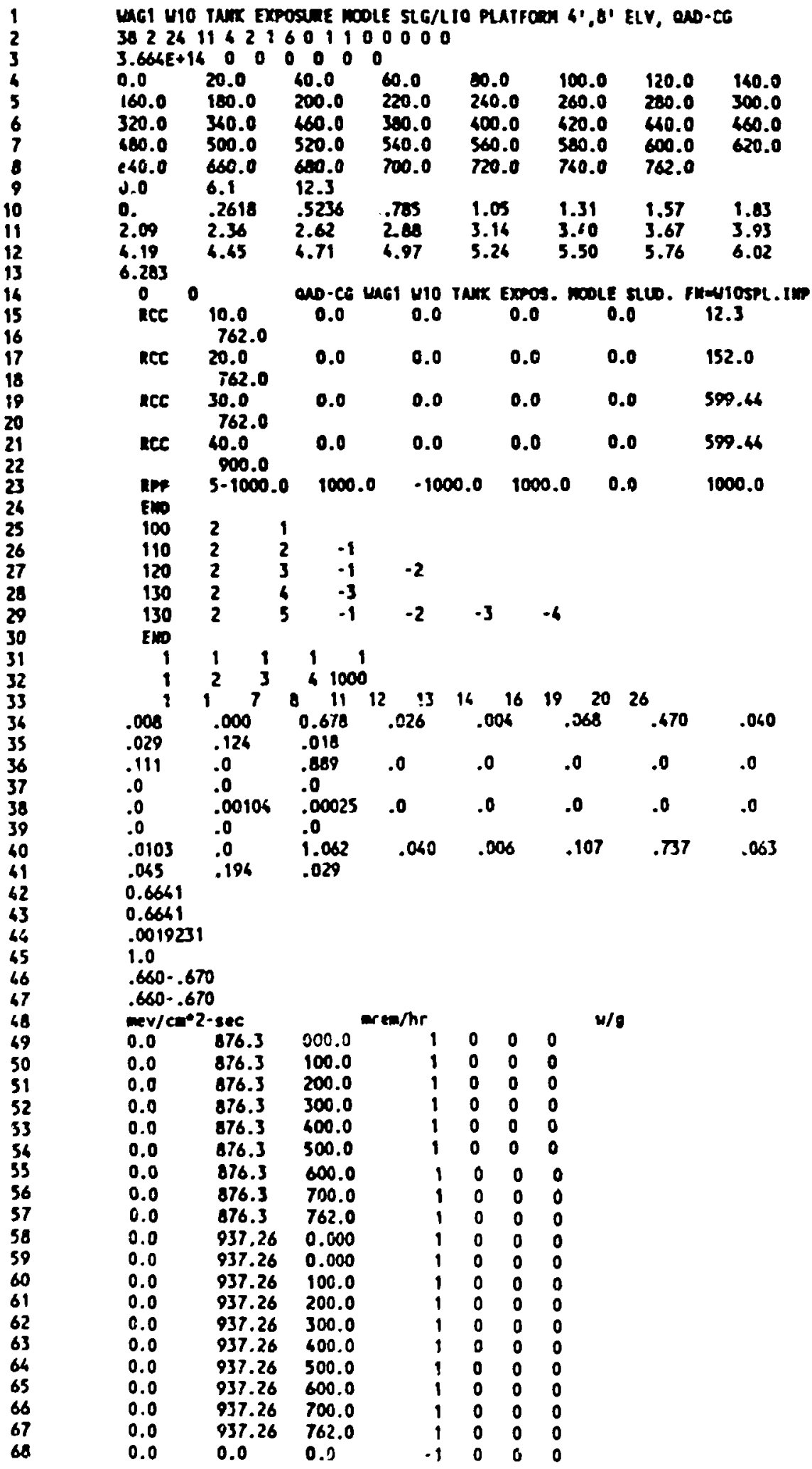


INPUI OAIA LIST

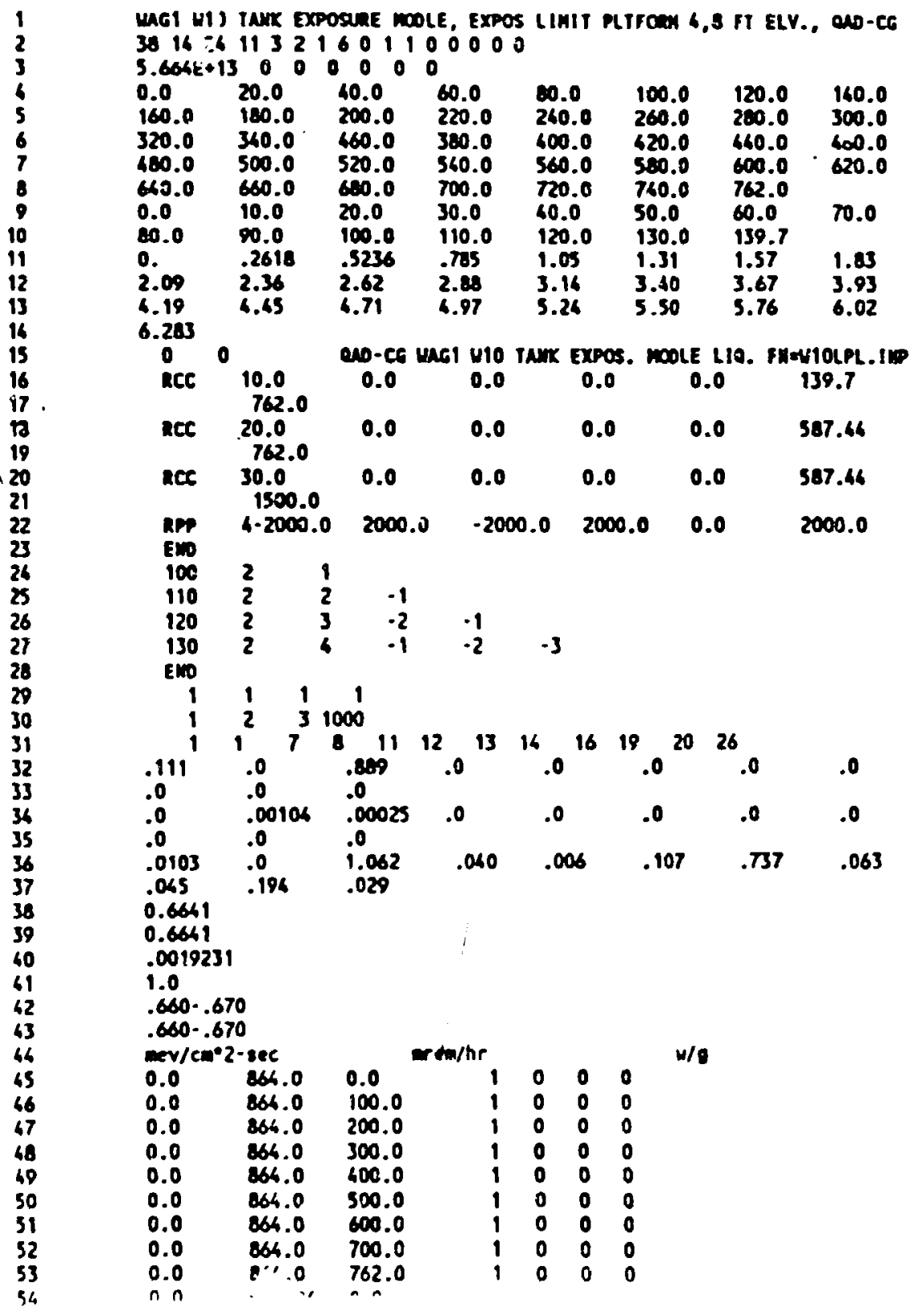


IMPUT DATA LIST

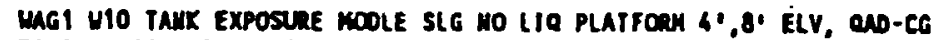
3822411321601100000 $3.664 E+160000000$

\begin{tabular}{|c|c|c|c|c|c|c|}
\hline $\begin{array}{l}0.0 \\
160.0 \\
320.0 \\
680.0 \\
640.0 \\
0.0\end{array}$ & $\begin{array}{l}20.0 \\
180.0 \\
360.0 \\
500.0 \\
660.0 \\
6.1\end{array}$ & $\begin{array}{l}60.0 \\
200.0 \\
660.0 \\
520.0 \\
680.0 \\
12.3\end{array}$ & $\begin{array}{l}60.0 \\
220.0 \\
300.0 \\
540.0 \\
700.0\end{array}$ & $\begin{array}{l}80.0 \\
260.0 \\
600.0 \\
560.0 \\
720.0\end{array}$ & $\begin{array}{l}120.0 \\
260.0 \\
420.0 \\
580.0 \\
740.0\end{array}$ & $\begin{array}{l}120.0 \\
280.0 \\
440.0 \\
600.0 \\
762.0\end{array}$ \\
\hline 2.09 & $\begin{array}{l}-2618 \\
2.36 \\
4.45\end{array}$ & $\begin{array}{l}.5236 \\
2.62 \\
4.71\end{array}$ & $\begin{array}{l}.785 \\
2.08 \\
6.97\end{array}$ & $\begin{array}{l}1.05 \\
3.16 \\
5.26\end{array}$ & $\begin{array}{l}1.31 \\
3.60 \\
5.50\end{array}$ & $\begin{array}{l}1.57 \\
3.67 \\
5.76\end{array}$ \\
\hline
\end{tabular}

6.283
0

QAD-CE WAGI W1O TAHK EXPOS. MOOLE SLLO. FH=W10SMPL. IMP

Rec 10.0

$0.0 \quad 0.0 \quad 0.0 \quad 0.0 \quad 12.3$

ReC $\quad 20.0$

762.0

RCC 30.0

$0.0 \quad 0.0$

0.0

0.0

152.0

$0.0 \quad 0.0$

0.0

0.0

599.46

ReC $\quad 40.0$

$0.0 \quad 0.0$

0.0

0.0

599.46

RPP $\quad 5.1000 .0$

$1000.0 \quad \cdot 1000.0$

1000.0

$0.0 \quad 1000.0$

100221

11022

120

130

130

ENO

11111

12231000

$008^{1}$

.029

$.029 \quad .126$

.0

.0

.0103

$.000^{7}$

$.126 \quad .018$

.00106

.00108

$.0 \quad .0$

$.194 \quad .029$

$\begin{array}{ll}-1 & \\ -1 & -2\end{array}$

$-2$

$\begin{array}{lll}-2 & -3 & -6\end{array}$

0.6641

.0019231

1.0

$.660 \cdot .670$

$.660 \cdot .670$

env/enez-sec

876.30000 .0

$\begin{array}{lll}0.0 & 876.30 \quad 100.0\end{array}$

$\begin{array}{lll}0.0 & 876.30 \quad 200.0\end{array}$

$0.0 \quad 876.30 \quad 300.0$

$\begin{array}{lll}0.0 & 876.30 \quad 400.0\end{array}$

$\begin{array}{lll}0.0 & 876.30 \quad 500.0\end{array}$

$\begin{array}{lll}0.0 & 876.30 \quad 600.0\end{array}$

$\begin{array}{lll}0.0 & 876.30 & 700.0\end{array}$

wrew/hr

$16 \quad 16$

$19 \quad 20 \quad 26$

26.670

.040

2

.0

$\begin{array}{llll}.0 & .0 & .0 & .0\end{array}$

$.040 \quad .006$

107.37

.063

36

$\begin{array}{llll}1 & 0 & 0 & 0 \\ 1 & 0 & 0 & 0 \\ 1 & 0 & 0 & 0 \\ 1 & 0 & 0 & 0 \\ 1 & 0 & 0 & 0 \\ 1 & 0 & 0 & 0 \\ 1 & 0 & 0 & 0 \\ 1 & 0 & 0 & 0\end{array}$

$w / 9$ 
IMPUT DATA LISI

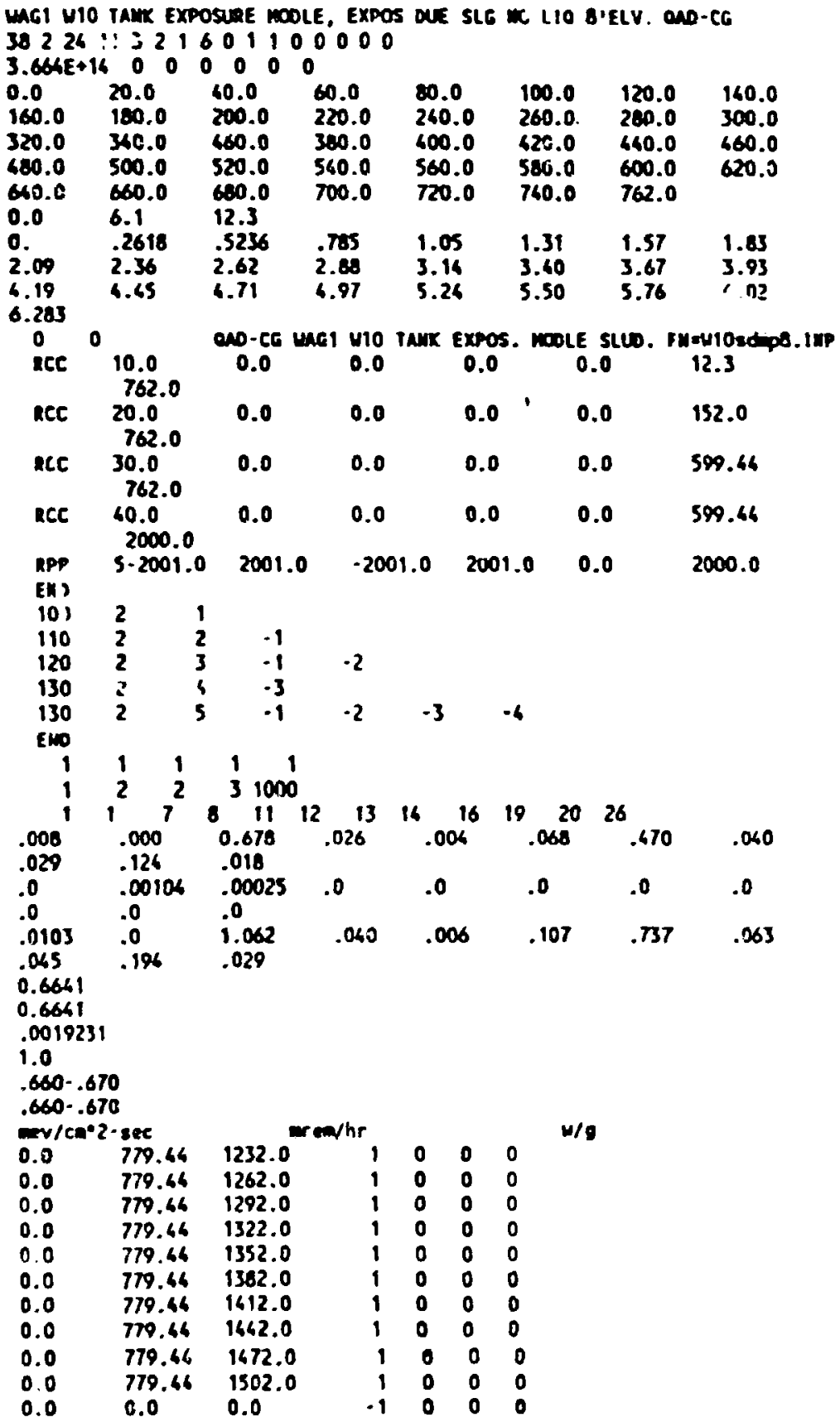




\section{C-16}

IMPUT DATA LIST

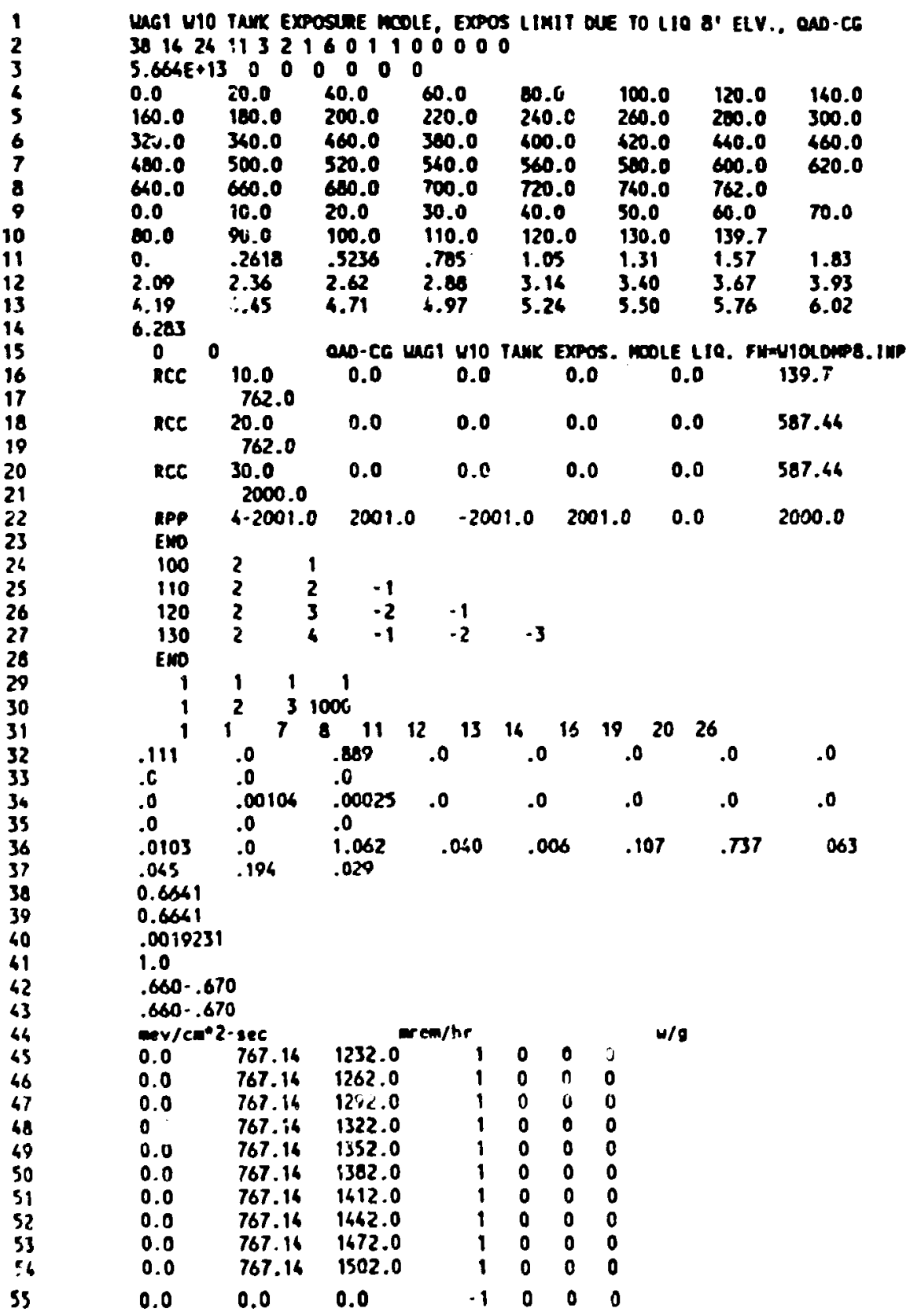




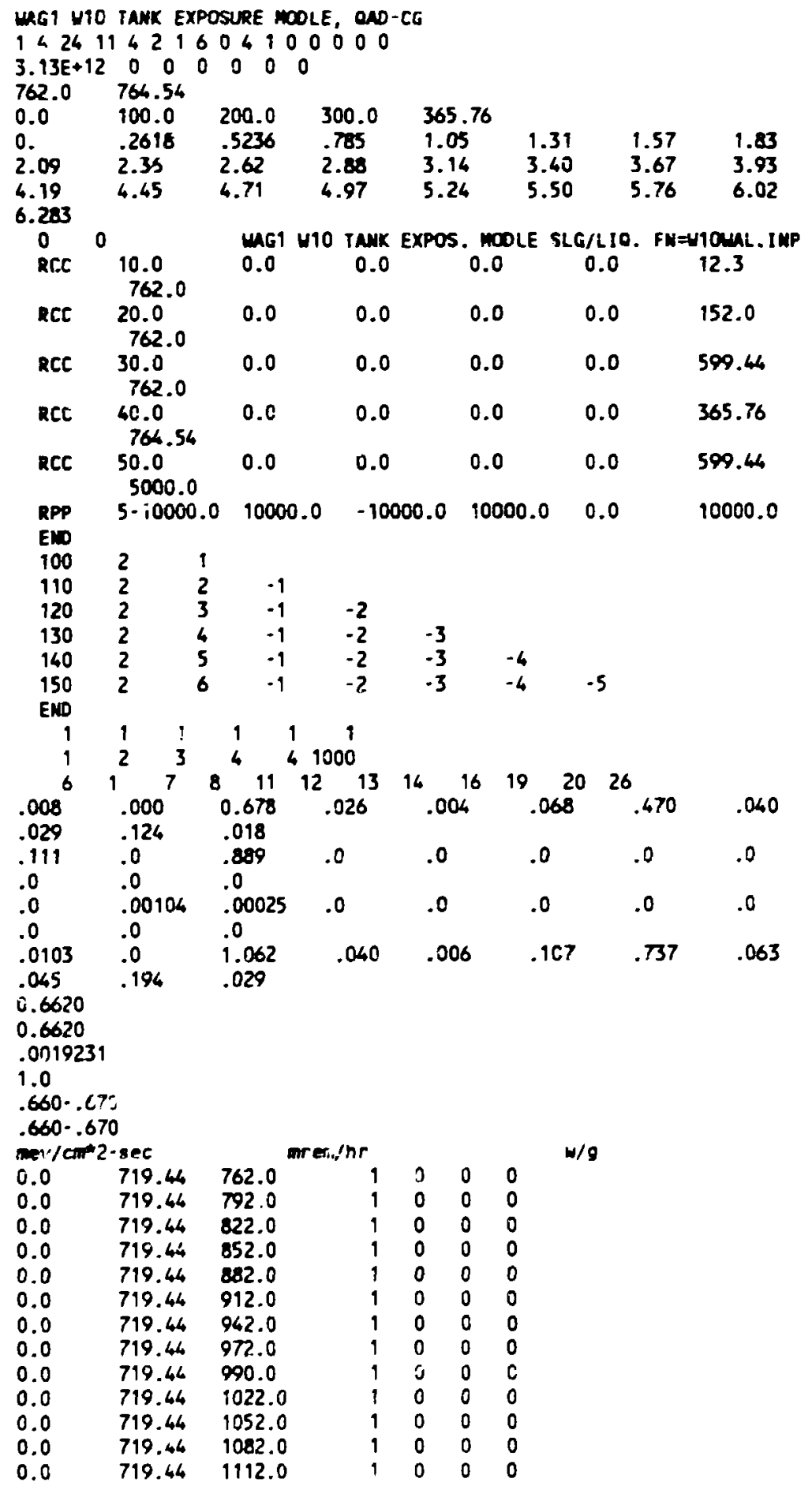


00000000000000000000000000000000000000000000000000000000000 00000000000000000000000000003000000000000000000000000000000 00000000000000000000000000000000000000000000000000000000000

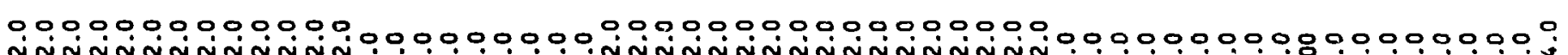

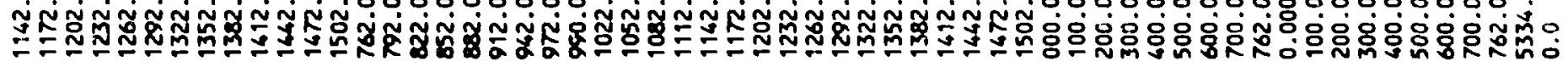

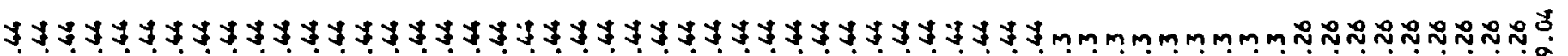

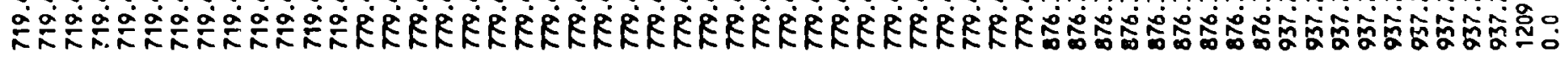

$0000000000000000000000000000000000000000000000=000000000000$

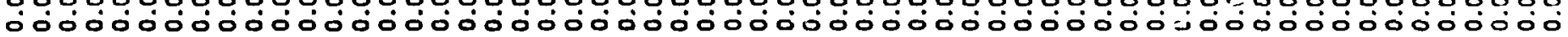




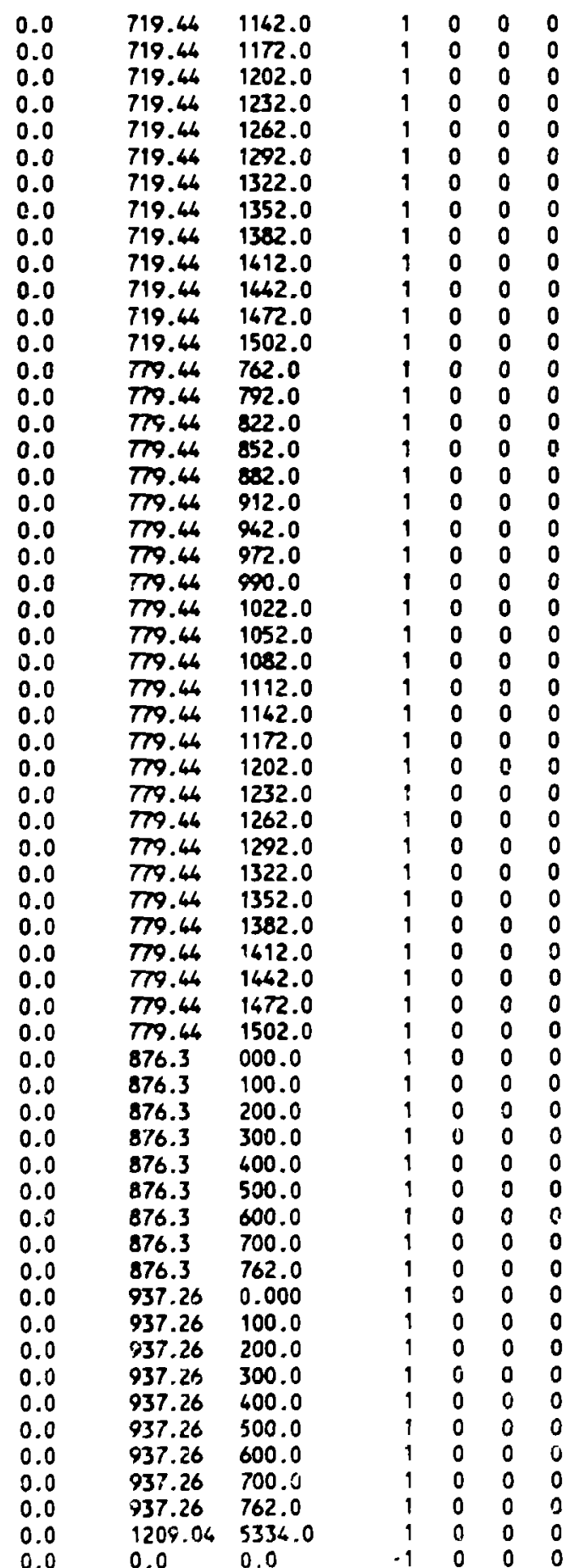




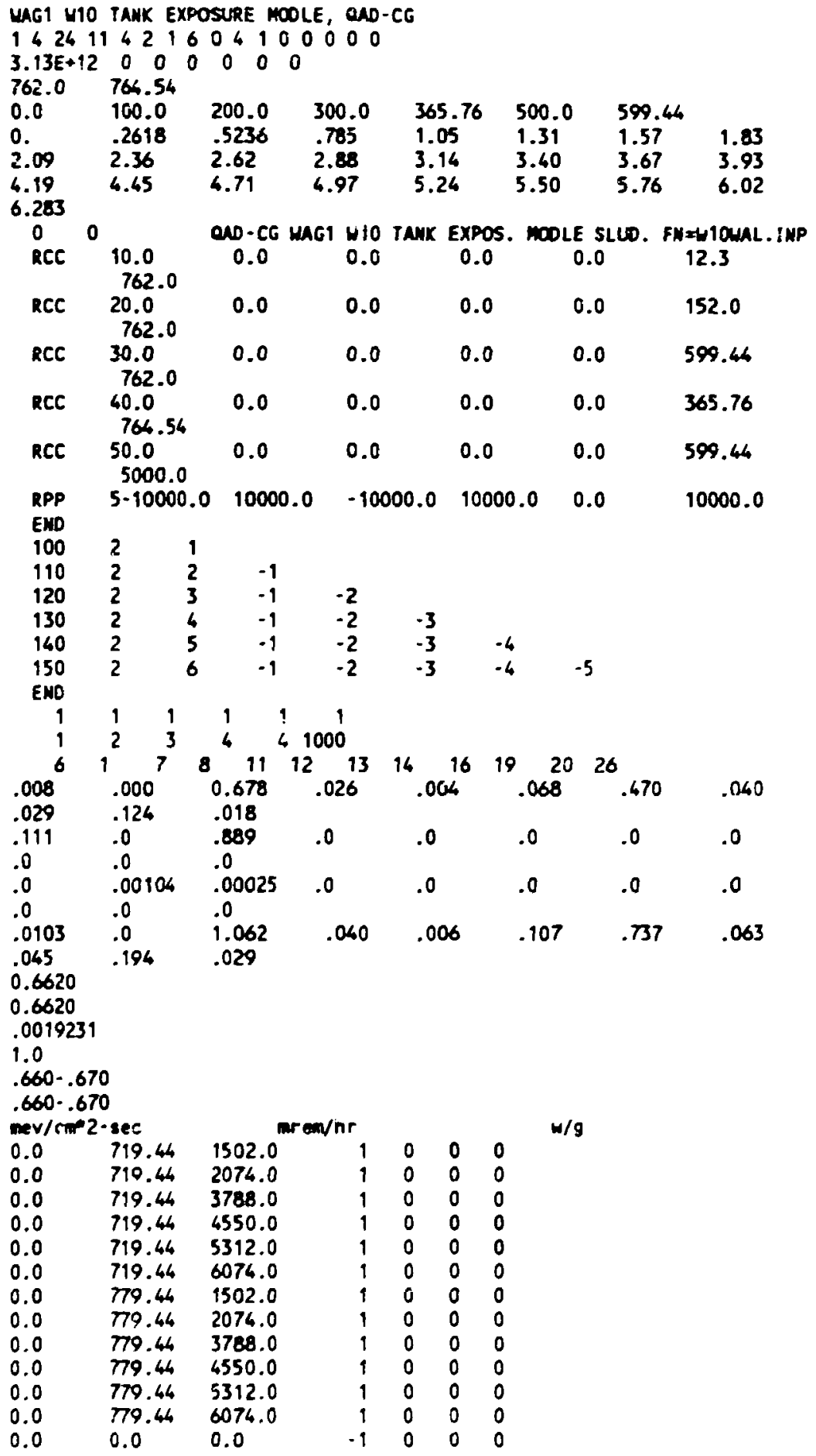




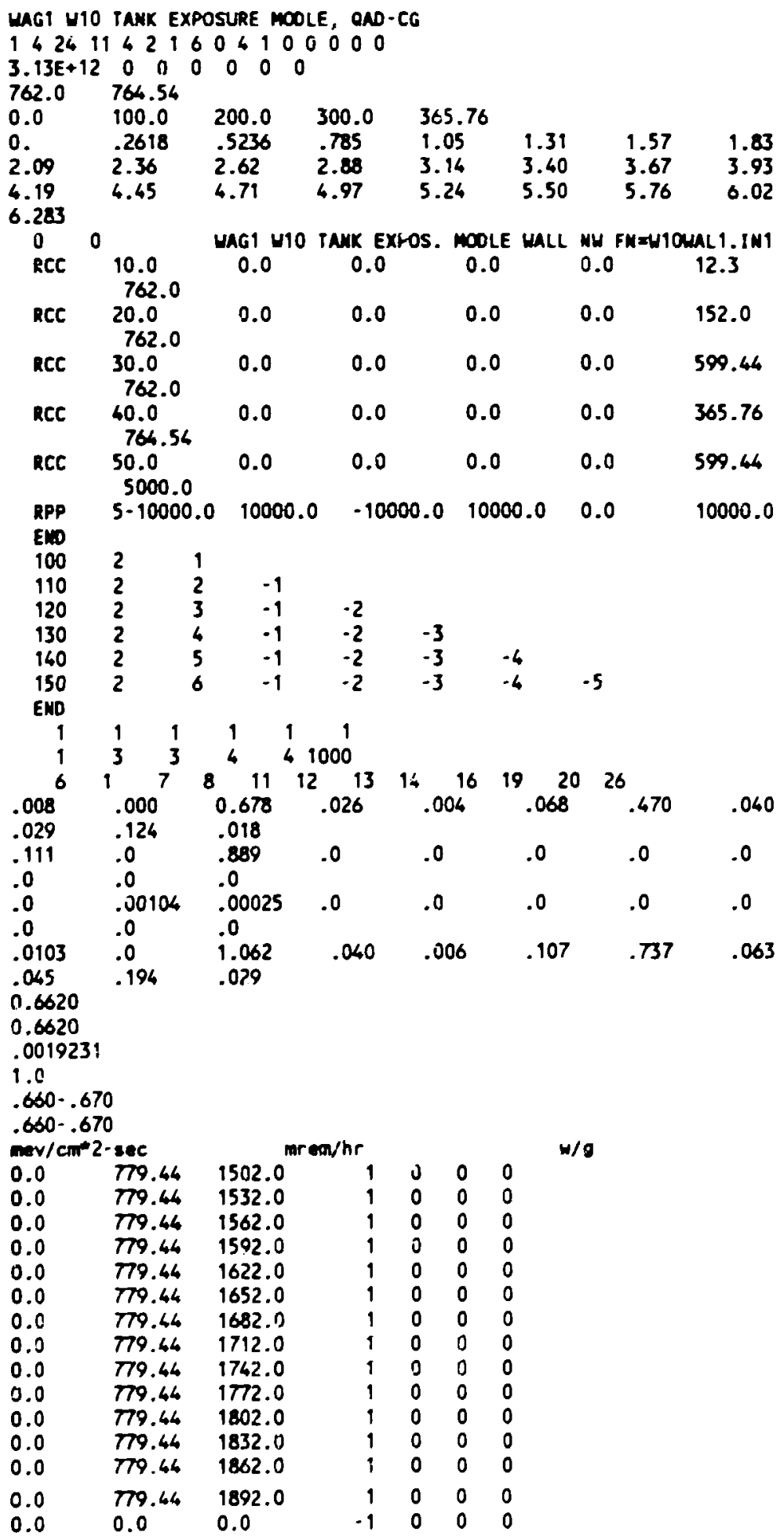




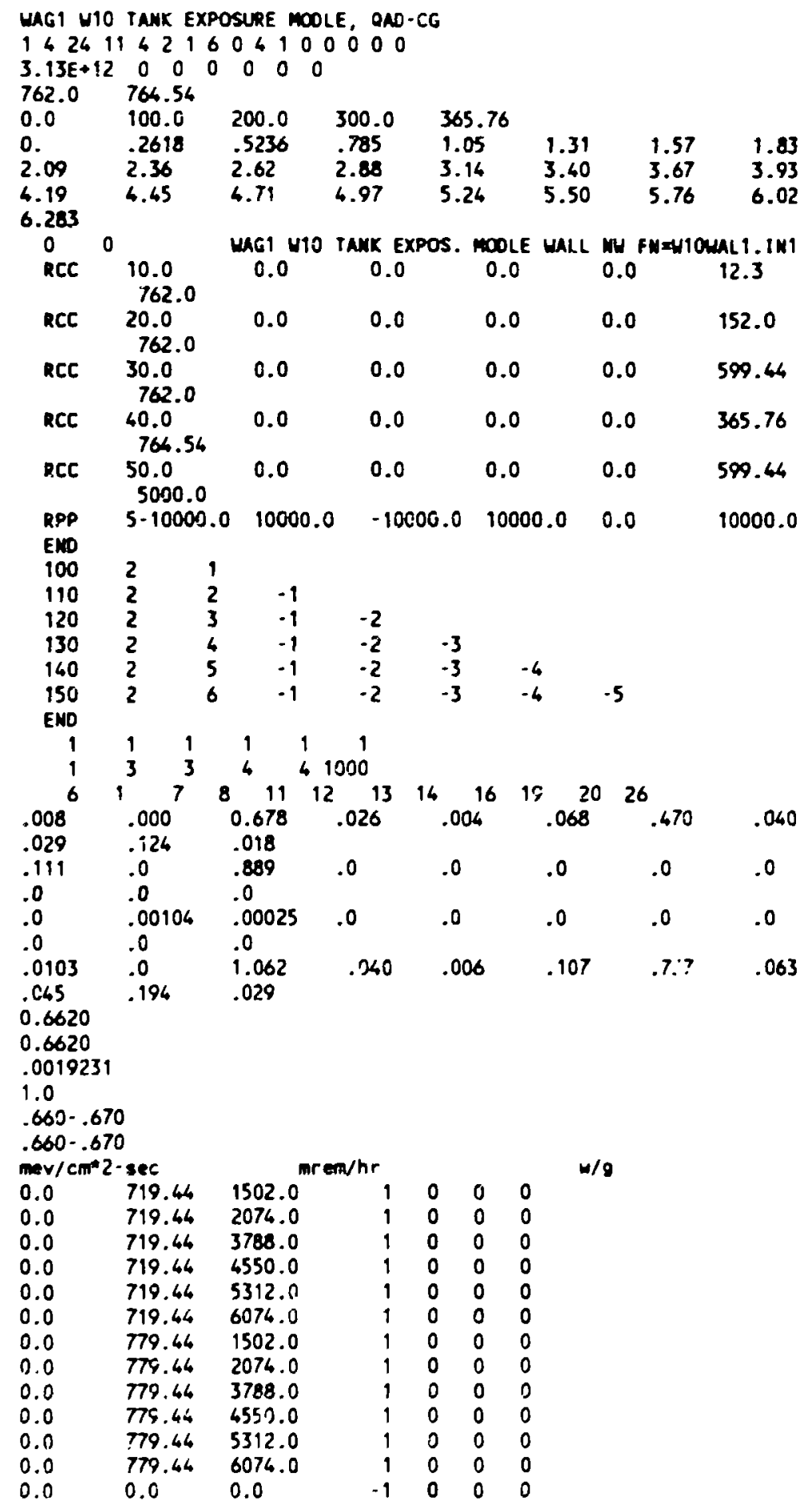


WAG1 W10 TAMK EXPOSURE mOOLE, EXPOS DUE SLG MO LIO BLDG, OND-CG 38226113216011000000

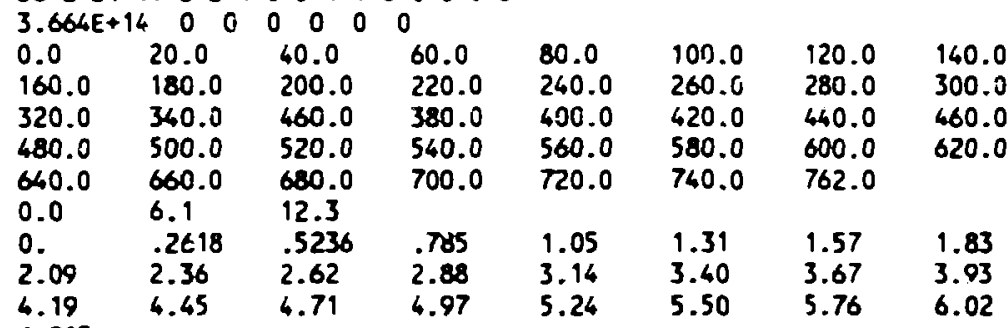

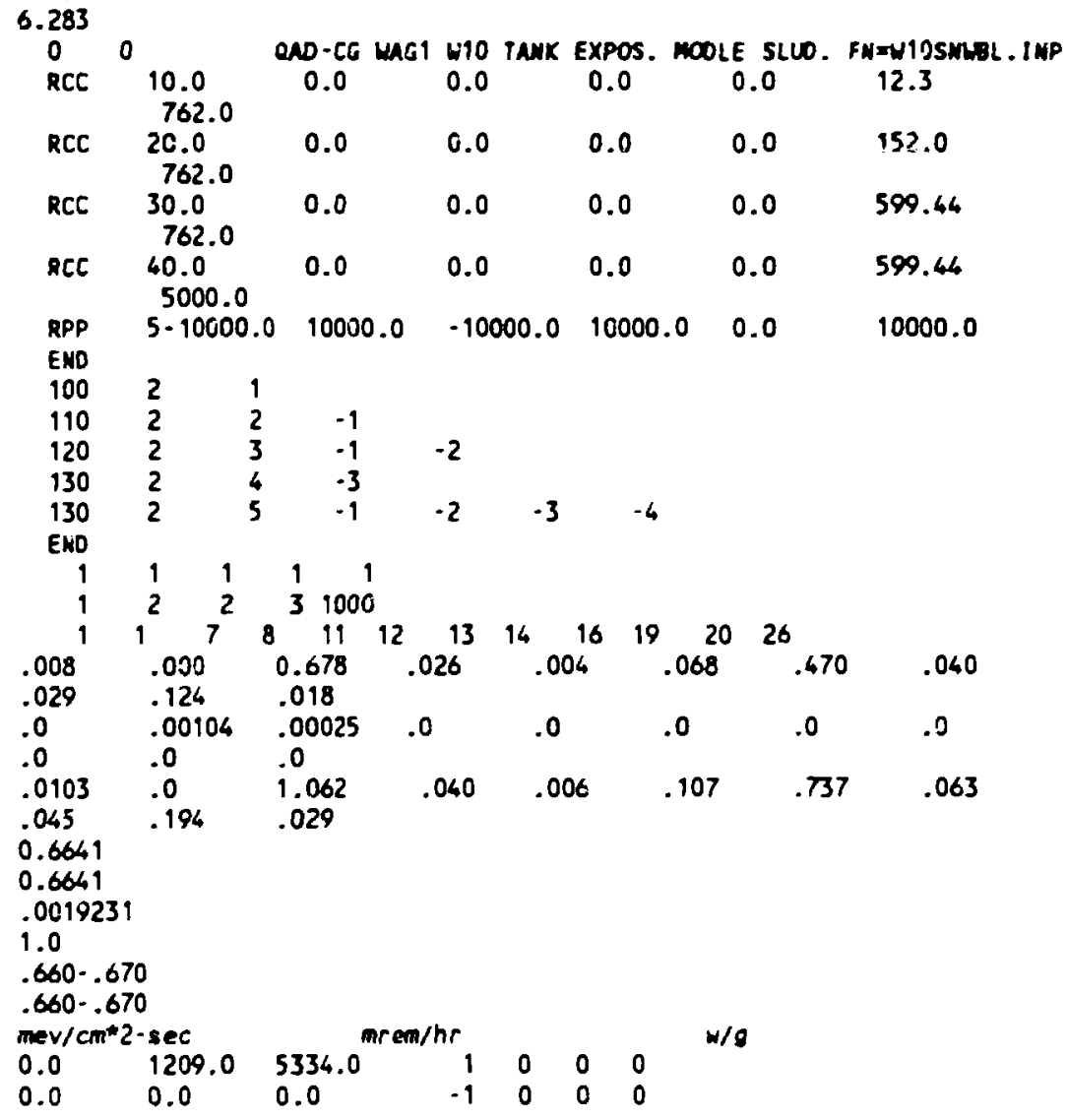


WAGI H1O TANX EXPOSURE MODLE, EXMPOS OUE TO SL WLS BLDC, OAO-CG

3822411421601100000

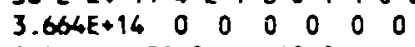

$\begin{array}{llllllll}0.0 & 20.0 & 40.0 & 60.0 & 80.0 & 100.0 & 120.0 & 140.0\end{array}$

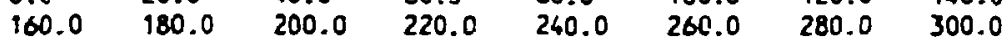

$\begin{array}{llllllll}320.0 & 340.0 & 460.0 & 380.0 & 400.0 & 420.0 & 460.0 & 460.0\end{array}$

$\begin{array}{llllllll}480.0 & 500.0 & 520.0 & 540.0 & 560.0 & 580.0 & 600.0 & 620.0\end{array}$

$\begin{array}{lllllll}640.0 & 660.0 & 680.0 & 700.0 & 720.0 & 740.0 & 762.0\end{array}$

$\begin{array}{llllllll}0.0 & 6.1 & 12.3 & & & & & \\ 0 . & .2518 & .5236 & .725 & 1.05 & 1.31 & 1.57 & 1.83\end{array}$

$\begin{array}{llllllll}2.09 & 2.36 & 2.62 & 2.88 & 3.16 & 3.40 & 3.67 & 3.93\end{array}$

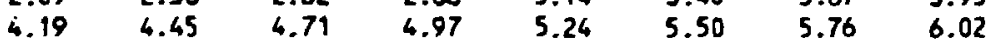

6.283

$\begin{array}{ll}0 & 0 \\ \text { RCC } & \end{array}$

10.0
762.

QMO-CG WAGT W1O TAMK EXPOS. MOOLE SLLO. FHXW1OSMLL. IMP

RCC $\quad 20.0$

$\quad 762.0$

RCC 30.0

ReC $\quad 40.0$

5000.0

$\begin{array}{lllll}0.0 & 0.0 & 0.0 & 0.0 & 12.3\end{array}$

$\begin{array}{lllll}0.0 & 0.0 & 0.0 & 0.0 & 152.0\end{array}$

$\begin{array}{lllll}0.0 & 0.0 & 0.0 & 0.0 & 599.46\end{array}$

$\begin{array}{lllll}0.0 & 0.0 & 0.0 & 0.0 & 599.44\end{array}$

$\begin{array}{lllllll}\text { RPP } & 5.10000 .0 & 10000.0 & -10000.0 & 10000.0 & 0.0 & 10000.0\end{array}$

END

$\begin{array}{lllllll}100 & 2 & 1 & & & & \\ 110 & 2 & 2 & -1 & & & \\ 120 & 2 & 3 & -1 & -2 & & \\ 130 & 2 & 4 & -3 & & & \\ 130 & 2 & 5 & -1 & -2 & -3 & -4 \\ \text { END } & & & & & & \end{array}$

END

1
1
1

$\begin{array}{lllr}1 & 1 & 1 & 1 \\ 2 & 3 & 4 & 1000\end{array}$

$\begin{array}{lllllllllll}1 & 7 & 8 & 11 & 12 & 13 & 1 \% & 16 & 19 & 20 & 26\end{array}$

$\begin{array}{llllllll}.008 & .000 & 0.678 & .026 & .004 & .068 & .470 & .040 \\ .029 & .126 & .018 & & .040 & \end{array}$

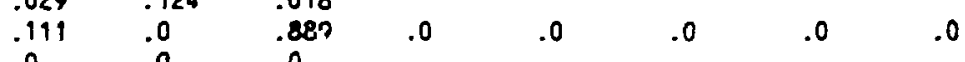

$.0 \quad .0 \quad .0$

$\begin{array}{llllllll}.0 & .0 & .0 & .0 & .0 & .0 & .0 \\ .0 & .00104 & .00025 & .0 & .0 & .0 & .0 & \end{array}$

$\begin{array}{llllllll}.0103 & .0 & 1.062 & .040 & .006 & .107 & .737 & .063\end{array}$

.045

$.194 \quad .029$

0.6641

.0019231

1.0

$.660-.670$

$.660-.670$

$\begin{array}{lllllll}\mathrm{mev} / \mathrm{cm} / 2 \cdot \mathrm{sec} & & & \mathrm{mrem} / \mathrm{hr} & & & \\ 0.0 & 1209.04 & 5334.0^{*} & 1 & 0 & 0 & 0\end{array}$

$w / g$

$\begin{array}{lllllll}0.0 & 0.0 & 0.0 & -1 & 0 & 0 & 0\end{array}$ 


\section{DISTRIBUTION}

1. C. W. Alexander

2 J. E Bigelow

3. T. M. Bonine

4. H. L Boston

5. W. D. Brickeen

6-7. K. F. Eckerman

8. J. T. Etheridge

9. J. B. Fuqua, Jr.

10. S. B. Garland

11. L L Kaiser

12. A J. Kuhaida

13-15. D. M. Matteo

16-17. P. T. Owen

18. C. E. Pepper

19. J. H. Platfoot

20. P. S. Rohwer

21. P. A Schrandt

22. W. T. Thompson

23. M. L. Whitehead

24. C. O. Wiles

25. P. S. Wood

26. ORNL ER Document Management Center

27. Central ER Document Management Center

28. Laboratory Records Department

29. ORNL Patent Section

30. Central Research Library

31. Office of Assistant Manager for Energy Research and Development, DOE Oak Ridge Operations Office, P.O. Box 2001, Oak Ridge, TN 37831-8600

32-33. Office of Scientific and Technical Information, P.O. Box 62, Oak Ridge, TN 37831 